\title{
MASTER
}

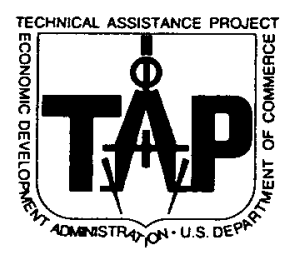

\section{ECONOMIC STUDY}

OF

\section{LOW TEMPERATURE GEOTHERMAL ENERGY}

IN

\section{LASSEN AND MODOC COUNTIES}

\section{CALIFORNIA}

\author{
PREPARED FOR THE \\ STATE OF CALIFORNIA \\ DIVISION OF OIL AND GAS \\ AND THE \\ ENERGY RESOURCES \\ CONSERVATION AND DEVELOPMENT COMMISSION
}

APRIL 1977

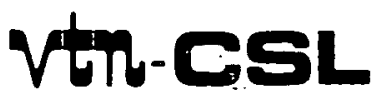

A joint venture of VTN Consolidated, Inc. and CSL Associates, Inc. 


\section{DISCLAIMER}

This report was prepared as an account of work sponsored by an agency of the United States Government. Neither the United States Government nor any agency Thereof, nor any of their employees, makes any warranty, express or implied, or assumes any legal liability or responsibility for the accuracy, completeness, or usefulness of any information, apparatus, product, or process disclosed, or represents that its use would not infringe privately owned rights. Reference herein to any specific commercial product, process, or service by trade name, trademark, manufacturer, or otherwise does not necessarily constitute or imply its endorsement, recommendation, or favoring by the United States Government or any agency thereof. The views and opinions of authors expressed herein do not necessarily state or reflect those of the United States Government or any agency thereof. 


\section{DISCLAIMER}

Portions of this document may be illegible in electronic image products. Images are produced from the best available original document. 


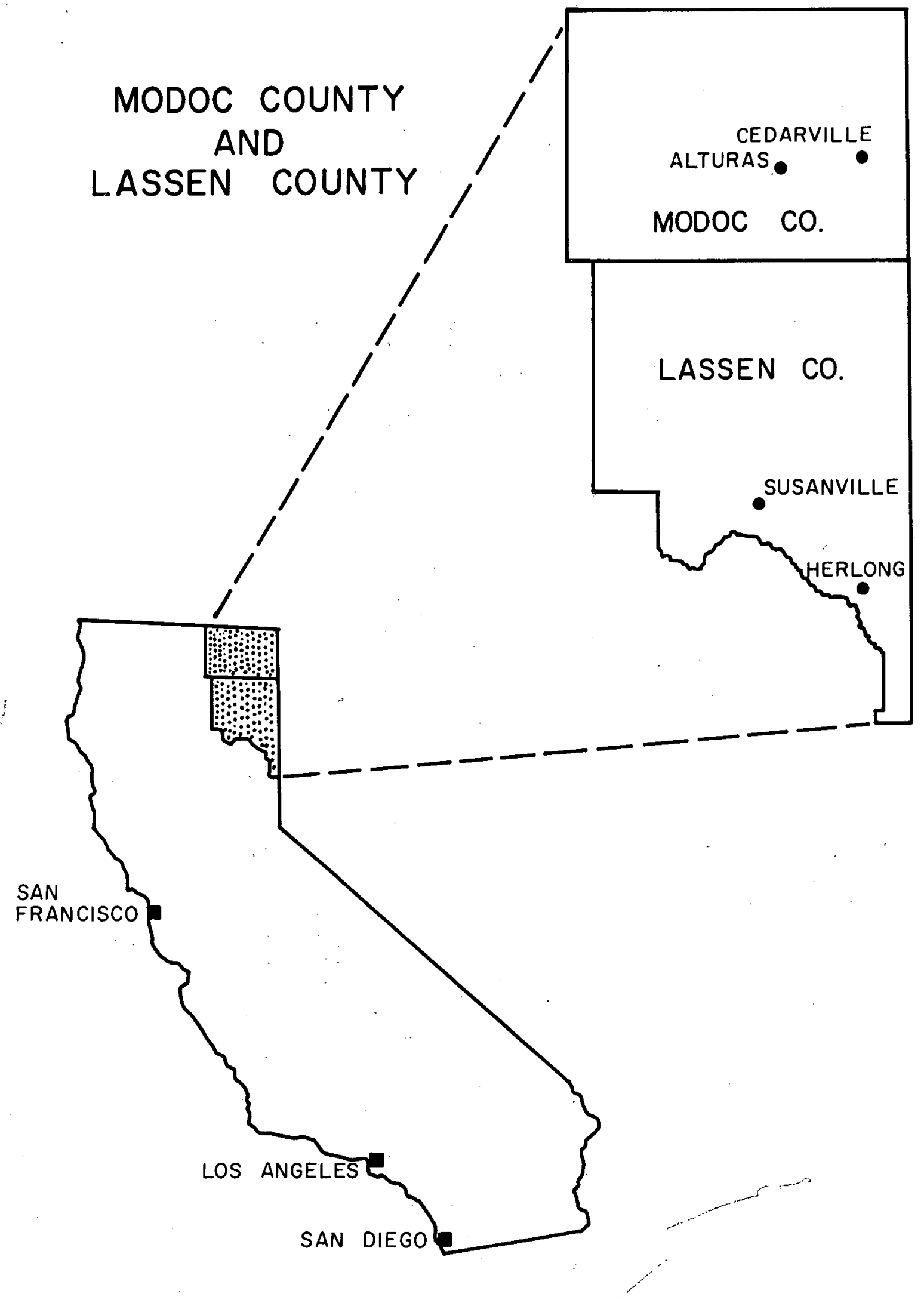




\author{
Prepared for \\ STATE OF CALIFORNIA \\ DEPARTMENT OF CONSERVATION \\ DIVISION OF OIL AND GAS \\ AND \\ ENERGY RESOURCES CONSERVATION AND \\ DEVELOPMENT COMMISSION \\ ECONOMIC STUDY OF LOW \\ TEMPERATURE GEOTHERMAL \\ ENERGY IN LASSEN AND \\ MODOC COUNTIES, CALIFORNIA \\ JOB $2175-3$
}

April, 1977

This technical study was accomplished by professional consultants under contract with the Division of $0 i l$ and Gas and project management by the Energy Resources Conservation and Development Commission, State of California through an Economic Development Administration Technical Assistance Grant. Statements, findings, conclusions, recommendations, and other data in this report are solely those of the contractor and do not necessarily reflect the view of the Division of $0 i 1$ and Gas, Energy Resources Conservation and Development.Commission or the Economic Development Administration.

Submitted by

VTN-CSL

A joint venture of VTN Consolidated Inc., and CSL Associates, Inc. 
TABLE OF CONTENTS

\section{Page}

I INTRODUCTION

II SUMMARY AND CONCLUSIONS

A. Key Findings

B. Recommendations and Conclusions

III PROJECT APPROACH AND BACKGROUND DATA
A. Scope of Effort
B. Methodology Employed
C. Description of Study Area
1. General Overview
2. Influence Factors and other sources of energy

IV SELECTION OF APPLICATIONS 23

$\checkmark$ APPLICATIONS 26

A. General 26

1. Business Considerations 26

2. Constraints 27

3. Cost of Geothermal Water Sys tems 27

4. Influence Factor Summary 29

B. Technical Analyses 37

1. Greenhouses 31

2. Kiln Drying 39

3. Onion Dehydration 45

4. Feedlots 51

5. Aquaculture 58

VI APPENDIX 65

A. Demographic and Economic Profile 65

B. References 86 


\section{LIST OF FIGURES}

Figure No.

Title

Page

II I-1

Location of major wells and hot springs

Major industrial sites

II -3

Highway and railroad map

III -4

Distances to major western markets

$v-1$

Contribution of energy savings to profit

$\mathrm{V}-2$

Annual cost of supply and reinjection systems

28

$v-3$

Well depth vs. temperature

29

V-4

One acre quonset hut greenhouse

Geothermally heated greenhouses--optimum well depth

Investment estimations for four different greenhouses

34

V-7

Kiln drying lumber

V-8

Onion dehydration plant--process flow sheet

$v-9$

Single component feedlot, unit capacity 600 head, 650 pound feeder cattle

Combination and design feedlot for 9000 head feeder cattle 


\section{LIST OF TABLES}

Table No.

Hot springs and hot-water wells in Lassen and Modoc Counties

Chemical constituents of thermal waters geothermal energy applications

Greenhouse to average field production

Greenhouse product economics

Typical kiln drying schedules

Estimated extra ration energy required to compensate for each unit of cold stress

Estimated apparent digestibilities of ration dry matter

Cost Summary, 18000 head feedlot arranged by ascending intensity of culture methods 
LIST OF TABLES (continued)

Table No.

Title

Page

A-1

Historical population

65

A-2

Modoc County population by age groupings

66

A-3

Lassen County population by age groupings

67

A-4

Modoc County employment by major categories

69 .

A-5

Lassen County employment by major categories

70

A-6

Historical unemployment rates (\%), Modoc and

71 Lassen Counties

A-7

Experienced unemployed by occupation Modoc

72 County--1972

A-8

Experienced unemployed by occupation Lassen County--1972

A-9

Family income: Lassen County and California

75

A-10

Family income: Modoc County and California 76

A-11

Lassen County: Personal income by major

77 source

Modoc County: Personal income by major

78 source

A-13

Agricultural production--value and rank

80

Modoc County, California

A-14

Agricultural production--value

81

Lassen County

A-15

Value of mineral products and timber production, Modoc County 1950-1971

82

A-16

Value of mineral products and timber production, Lassen County, 1950-1968

Assessed valuation of County--Assessed tangible property by class of property for Lassen County, 1940-1970

Assessed valuation of County--Assessed tangible property by class of property for 85 Modoc County 1940-1970 


\section{INTRODUCTION}

The Economic Study of Low Temperature Geothermal Energy in Lassen and Modoc Counties, California presented herein was authorized by the Department of Conservation, Division of $0 i 1$ and Gas under Economic Development Administration Technical Assistance Grant No. 07-06-01522. Project Management has been performed by Mr. David N. Anderson, and Ms. Syd Willard of the California Energy Resources Conservation and Development Commission, Al ternatives Implementation Division. Mr. Anderson was previously assigned as State Geothermal officer, Division of $0 i 1$ and Gas, during the formulation of this study contract.

The purpose of this study was to investigate the feasibility of using low cost, low temperature geothermal energy in job-producing industries to increase employment and encourage economic development. The study, encompassing all of Lassen and Modoc Counties, was to be site-specific, referencing candidate geothermal applications to known hot wells and springs as previously determined, or to new wells with specific characteristics as defined in the Scope of Work. The emphas is was to be placed on economically practical and readily achievable applications from known resources, thus complimenting the recently completed ERDA-Susanville Study where a designated community was used as a "laboratory" in. which land-use planning, institutional aspects, geological assessments, technical modeling and socioeconomic impacts were all examined in overview.

During the course of the study, monthly progress reports were prepared and reviewed with the Commission so that emphas is on particular features of study could be changed as necessary to reflect updated findings and to redirect efforts into additional areas of potential promise as they became apparent. In this manner, a degree of flexibility was maintained which allowed a more comprehensive study than would have been otherwise possible.

Although the report generates both positive and negative findings in specific areas of investigation, it is felt that the overall long term prognosis for geothermal energy stimulus to industry in the area is excellent.

In addition to acknowledging indebtedness to the many investigators in the field of low temperature geothermal energy, additional thanks are due to Dr. E. Barmettler for his consulting assistance in the economics of agriculture and aquacultural applications; to several specialists at U.C. Davis who gave freely of their time, Dr. Allen Knight, Dr. Verne Mendel, Dr. Ralph Ernst, Dr. Hubert Heitman and John Dunbar; : to Mr. Jim Aslette, Ray Newton and Dr. H. Adams for helping in the investigation of potato applications; to Wes Davis and Merritt Thompson for suggestions on greenhouses; to William Main and Lyle Carter for providing dry kiln information; to Roy Conners for well drilling cost data; to Fred Wieters on for information on food processing equipment; to John Robison and Kenneth Rose for background on agricultural applications in Surprise Valley; to Bill Johns on at 0.I.T. for his guidance on prawn aquaculture; and especially to Judy Hannah for her work on the location and properties of geothermal springs and wells. 


\section{SUMMARY AND CONCLUSIONS}

\section{A. KEY FINDINGS}

- Greenhouse operations in Lassen and Modoc Counties using geothermal energy can be quite competftive with conventional installations located in more favorable climatic and marketing areas. This is the most laborand-energy-intensive of all applicattons studied. The dependability of geothermal energy, as compared to the interruptible nature of gas supplies for this industry, further enhances the importance of this application.

- Wood kilns involved in lumber mill operations can be operated with geothermal hot water at approximately 50\% of the energy cost of fossil fuel systems. However, while bark and chips are of commercial value, more than ample low value sawdust normally is generated to fuel the kilns. The economic feasibility of employing geothermal water in kiln drying depends on the successful development of sawdust usage for other applications.

- Converting an onion drying facility from oil to all geothermal can save over one half the cost of heat energy. (The all geothermal system requires water at $240 \mathrm{~F}$.)

- Geothermally heated feed lots can furnish an assist to the economically depressed cattle industry in the area.

- The commercial economics of geothermal applications to aquaculture are not favorable under current limitations in consumer tastes, crop yield rates and growing technology.

- Space heating of commercial, residential and public buildings can be an economic and fossil energy-conserving adjunct to these process applications.

- While the use of low temperature geothermal energy can contribute to the profitability and competitiveness of many operations, the energy component of product costs in the areas of study is low. The feasibility of any given geothermal application is particularly sensitive to scale of operation, in addition to many business factors not related to the geothermal resource.

\section{B. RECOMMENDATIONS AND CONCLUSIONS}

The prospect of using low temperature geothermal water for some applications is quite promising at present and will certainly continue to grow as conventional sources of energy become more costly and scarce, and research opens new commercial options. This would appear to be particularly true for forest products and aquaculture. These subjects are discussed in some detail in the technical sections of this study. 
In order to expand the nonelectrical geothermal applications for the LassenModoc County area, it is felt that addittonal study is warranted in several areas:

- The scope of this study was spectfically 1 fmited to temperatures of $212^{\circ} \mathrm{P}$ or below. Since the study area, particularly in the Wendel-Amedee and Surprise Valley areas, contains demonstrated resources at much higher temperatures which still may be unsuitable for producing electrical power, the definftion of "Low Temperature" should be extended to about $350 \mathrm{~F}$. Many processes excluded from this study, such as canning, sugar beet and potato processing, and refrigeration could have then been considered.

- Establish a demonstration project encompassing a geothermally heated feedlot to obtain empirical data and participation of local ranchers. Several ranchers interviewed expressed interest in this concept. The possibitities of a cooperative should be evaluated.

- Estabi ish a demonstration project for geothermal energy to be used in conjunction with exciting new advances in hydroponically grown cattle feeds and other agricultural products. The geothermal energy would control both the atmosphere in the greenhouse and the temperature of the nutritive liquids.

- Establish demonstration projects for geothermal dehydration of onions, and garlic. A trade organization presently exists and their cooperation should be solicited.

- Investigate the possibility of establishing a high density multi-use geothermal industrial park, thus minimizing shared cost of capitalized assets such as wells and distribution systems and incorporating efficiencies of cascaded and clustered construction. Survey and identify specific companies who would be interested in participating. An ideal list of participants would include users with approximately equal thermal loads, each of which would extract its heat over a different temperature range. Such a 7 ist. might include cascaded use by a refrigeration plant, a food processing plant, a greenhouse and a heated feed lot extracting heat at $270-300^{\circ} \mathrm{F}, 240-270^{\circ} \mathrm{F}, 210-240^{\circ} \mathrm{F}$ and $140-210^{\circ} \mathrm{F}$ respectively. 
This section describes the scope of work covered in the report and the methods of analysis used to collect and interpret data. A brief description of the Lassen and Modoc County study area is provided and several factors which influence the application of geothermal energy are dtscussed.

\section{A. SCOPE OF EFFORT}

A summary of the Scope of Work as defined by the Division of $0 i 7$ and Gas and presented in the study is outlined below.

\section{Purpose}

The purpose of the study is to provide usable data on the potential utilization of geothermal resources in specific job-producing industries which could be used to increase employment and encourage economic development. Its atm is to show whether use of low-cost geothermal energy can reduce the cost of producing goods; and if factual information on how and where this can be done is provided to potential producers, developers, and investors, to see if new business can be attracted and new jobs created.

The study's purpose is to analyze several specific industries that can utilize low temperature geothermal energy to reduce product cost, to estimate the magnitude of potential competitive advantages to the industries, and to publish those analyses and back-up data. State and local agencies will subsequently distribute the published information. In addition, the State will provide a six month follow-up program to bring potential users into direct contact with geothermal operations.

\section{Assumptions and Considerations}

a. Geothermal resources exist in quantities at usable temperatures in several separate localities of Lassen and Modoc counties.

b. Shallow geothermal reservoirs can be explored, drilled and tested and found to be productive at rates which will allow commercial development.

c. Use of geothermal water warmer than $212^{\circ} . \mathrm{F}$ or boiling at the altitude of occurrence will not be constdered. Temperatures above $212^{\circ} \mathrm{F}$ witl undoubtedly be found during the exploration and exploitation of hot springs complexes and during exploration for deep high temperature reservotrs for power generation. This constraint was made in order to make $t$ t easter for the in. dividual, "back-yard" user. If the temperature is above botling, additional precautions would have to be taken by the well driller and operator of the resource.

d. A geothermal well with the following characteristics will be developable.

We11: 300-feet deep, production $260 \mathrm{gpm}(1,000$ liters per minute) or greater, 6" casing. 
Pump: Capacity of $260 \mathrm{gpm}(1,000$ liters per minute)

Discharge pressure of 25 psi or greater.

e. Used geothermal waters shall be reinjected into the ground via a wel1.

3. Work Plan

a. Review published and unpublished data provided by the Division of $0 i 1$ and Gas and other sources, and rank the thermal springs and wells in Lassen and Modoc counties by temperature.

b. Develop a candidate list of ten products or processes from the following four categories. The candidate processes should be chosen for their potential direct use of hot water energy within the specified temperature ranges.

- Controllèd environmental (greenhouse) growing of agricultural products.

- Livestock production.

- Food processing and storage.

- Manufacturing.

c. The Division of $0 i 1$ and Gas, in consultation with the contractor, will at the end of the first month of operation select five of these products or processes for intensive study.

d. For each product or process, an analysis shall be prepared showing production costs using conventional energy (fuel oil, electricity or other appropriate fuel), and production costs utilizing geothermal energy to a maximum. Process flow diagrams shal1 be developed and complete ready-for-market costs shall be determined for both conventional production and production utilizing geothermal energy. Current wholesale prices for similar goods shall be determined for nearby market areas.

Each analysis should consider the variation of the product price to the various water temperature ranges. Additional heat may be necessary from conventional fuels in order to achieve temperature for certain processes or to meet seasonal or peaking requirements.

Changes in temperature ranges would affect these requirements and production costs.

Each analysis should consider the following factors plus other items where appropriate. Each factor should be discussed as to its economic influence on total production cost: 
- Crimate

- Fresh Water Requirements

- Shipping

- Marketing

- Labor

- Terrain

- Environmental Considerations

- Research

- Quality of Geothermal Fluids

- Multi-Use

- Quality of Product

- Temperature Enhancement (Process Requirement)

- Peaking Temperature (Weather Requirement)

- Uninterruptable Supply

\section{B. METHODOLOGY EMPLOYED}

Data for this report was collected in cooperation with the State Energy Commission and through use of their reference materials. Field trips were made to Lassen and Modoc Counties. Geothermal hot springs and we 11 sites were visited. A geologist familiar with the area was retained to consult on location and to characterize the resources. Local officials, land owners and businessmen were interviewed to determine the degree of local interest in use of geothermal energy for existing and proposed businesses.

An agricultural economist consultant provided assistance in evaluating agriculture and agricultural applications. This was bolstered by consultation with experts in specific fields of application at U.C. Davis. Personnel in private business operations in food processing and wood kiln drying were contacted. as were manufacturers of equipment.: They provided technical guidance and extended our list of reference literature.

Engineering heat and material balances and analyses of influence factors were accomplished using conventional techniques, and these were incorporated in the economic analyses. Recomiendations and conclusions based on these findings are presented in the summary, part II.

\section{DESCRIPTION OF THE STUDY AREA}

The study covers five geothermally active areas in Northeastern California: the Susanville, Wendel-Amedee and Big Valley areas in Lassen County and the Surprise 
Valley and Pit River areas in Modoc County. These areas are on the east slopes of the junction of the Sierra and Cascade Mountatns. The areas are typified by forested mountains in the west and high (4,000-feet elevation), semi-arid range land and intervening mountains of the basin and range province.

The economy of both counties is heavily dependent on forest products, agriculture and ranching. Lassen County also supports a large segment of its population through government employment at the Sierra Army Ordnance Depot and at the California Conservation Center, a State Prison.

The areas have been classified by the U.S. Department of Commerce as economically depressed. In some areas employment is highly seasonal with unemployment figures as high as 25 percent. Appendix A provides a demographic and economic profile of the counties, including data on population, population trends, unemployment history, work skills, agricultural and manufacturing production and assessed property valuations.

\section{General Overview}

Lassen County, population about 18,000, and Modoc County, population about 6,000, are characterized by small, scattered communities. Susanville, with a population of about 7,000, and Alturas, with a population of approximately 3,000 , are the only incorporated cities and major population centers in Lassen and Modoc Counties, respectively.

Geothermal springs and wells are also scattered throughout the counties. The flow rates depths and temperatures are reproduced from reference 2 in Table III- 1 and their locations are shown on the map in Figure III- 1 .

Geothermally heated greenhouses are located at Susanville and at Wendel Hot Springs. Lumber is the major industry of the area. Coin Lumber and Eagle Lake Lumber companies are located in Susanville and heat their kilns by burning wood waste products. Main Industries located near Bieber heats its kiln by burning number 2 fuel $0 i 1$.

Figure III-2 illustrates the locations of the greenhouses and lumber companies.

Federal Route 395, the major north-south road, services Reno, Susanville and Alturas. See Figure III-3. Adequate secondary roads are available over the mountains to the west and northwest. Southern Pacific Railroad service is also available from Reno to Susanville and Alturas, and a branch line extends east from Alturas through Homestead Siding where it crosses the Burlington Northern line.

Further south, the Burlington Northern line intersects the Western Pacific tracks so that transshipment is available to all major west coast cities. Another branch of Southern Pacific track; between Susanville and Westwood where it meets Western Pacific, is currently inoperative so that rail traffic from Susanville to the west must detour north through Alturas or south through Reno.

Reno is the only major market area less than 100 miles from the geothermal areas. The relative distances between these areas and other major markets in California, Oregon, Nevada and Idaho are illustrated in Figure III-4. 
TABLE III-1

\section{HOT SPRINGS AND HOT-WATER WELLS IN \\ NORTHERN CALIFORNIA}

No. Name of Spring or Well

(A) Surprise Valley

(1) Peterson's Ranch

(2) Bucher's well

(3) Ft. Bidwell well

(4) Lake City mud volcano and hot springs

(5) Wells (to $1,368 \mathrm{~m}$ )

(6) Hutchen's well (124 m)

(7) Well (194 m)

(8) Robison's well (77 m)

(9) Seyferth Hot Springs

(10) Leonard. Hot Springs (west)

(11) Leonard Hot Springs (east)

(12) Hot Spring

(13) Hot Springs Hotel wells

(14) Hot Springs Hotel springs

(15) Benmac Hot Springs

(16) Menlo Hot Springs

(17) Squaw Bath

\section{Location}

SE $1 / 4, N W 1 / 4, S e c .8, T .46 N$, R.16E. SW $1 / 4$, SE $1 / 4$, Sec. $8, T .46 N ., R .16 E$. NW $1 / 4, N E 1 / 4$, Sec. $17, T .46$ N.,R.16E. Sec. $24, T .44 N ., R .15 E$.

near Lake City

SW $1 / 4, N E 1 / 4$, Sec. $20, T .43$ N.,R.16E. SW $1 / 4, N W 1 / 4$, Sec. $20, T .43 N ., R .16 E$. NE1/4,SW1/4,Sec.30,T.43N.,R.16E. NW1/4,NW1/4,Sec. 12,T.43N.,R.16E. NW $1 / 4, N E 1 / 4$, Sec. $13, T .43 N$, R.17E. NE1/4,NE1/4,Sec. 13,T.43N.,R.17E. NW $1 / 4$, SE $1 / 4$, Sec. 6,T.42N.,R.17E. NE $1 / 4, S W_{1} / 4$, Sec. $6, T .42 N ., R .17 E$. SE $1 / 4, S W_{1} / 4$, Sec. $6, T .42 N ., R .17 E$. SU $1 / 4, S W / 4$, Sec. $6, T .42 N ., R .17 E$. NEl/4,NE1/4,Sec. 7,T.39N.,R.17E. NE $1 / 4, N W 1 / 4$, Sec. $29, T .38$ N.,R.17E.

$\begin{array}{ccc}\text { Temp } & \text { Flow } \\ { }^{0 C}{ }^{0} & \left.{ }^{0} \mathrm{~F}\right) & (1 / \mathrm{min})\end{array}$

$\begin{array}{llr}36-42 & 97-108 & 400 \\ 36 & 97 & 8,300^{*} \\ 37 & 99 & 600 \\ 48-97 & 118-207 & 400 \\ & & \\ 160 & 320 & \text { N.A. } \\ 48 & 118 & 9,460^{*} \\ 69 & 156 & 570^{*} \\ 50 & 122 & 605^{\circ} \\ 85 & 185 & 500 \\ 65 & 149 & 200 \\ 62 & 144 & 150 \\ 95 & 203 & \text { N.A. } \\ 84-98 & 183-208 & 300 \\ 50-54 & 122-129 & 1,800 \\ 96-97 & 205-207 & 750 \\ 57 & 135 & 1,000 \\ 49 & 120 & 450\end{array}$

(B) Alturas Area

(18) Hot Creek Ranch

(19) Kelly Hot Spring

(20) Well * (977 m)

(21) New William's Ranch well $(62 \mathrm{~m})$

(22) Old William's Ranch well

(23) West Valley Res. Hot Spring
SE1/4,Sec.9,T.42N.,R.11E.

NE $1 / 4$, Sec. 29, T.42N.,R.10E.

Sec. $29, T .42$ N.,R.10E.

SE $1 / 4$, SW $1 / 4$, Sec. $30, T .40 N$, R.13E. SW1/4,NW1/4,Sec. $31, T .40 N$, R.13E. SW $1 / 4, N E 1 / 4, \operatorname{Sec} .29, T .39 N ., R .14$ E.
33

92

110

29

44

74

$\begin{array}{rr}91 & 500 \\ 198 & 1,200 \\ 230 & \text { N.A. } \\ 84 & 150 \\ 111 & 150 \\ 165 & 1\end{array}$

(C) Big Valley and Little Hot Spring Valley

(24) Bassett Hot Spring

(25) Kellog Hot Spring

(26) Little Hot Springs

(D) Susanville

(27) Roosevelt Swimming Pool well (37 m)

(28) L.D.S. Church well $(181 \mathrm{~m})$

(29) Miller's Custom Work well

(E) Wendel-Amedee

(30) Wendel Hot Springs

(31) Well (189 m)

(32) Amedee Hot Springs

(33) Wells (to $334 \mathrm{~m}$ )

(34) Doyle Hot Spring *
NW $1 / 4, S E I / 4, S e c .12, T .38 N ., R .7 E$. SW $1 / 4, S E 1 / 4, S e c .15, T .38$ N.,R.8E. NW1/4,SW1/4,Sec. 9,T.39N.,R.5E.

NE1/4,NE1/4,Sec. 6,T.29N.,R.12E. 36

SW $1 / 4, N W 1 / 4$, Sec. 5,T.29N.,R.12E. NEI/4,NW1/4,Sec. 5,T.29N.,R.12E.

$\begin{array}{llr}79 & 174 & 200 \\ 78 & 172 & 15 \\ 75-77 & 167-171 & 300\end{array}$

Temperature and how measured during pump test. - Not located on maps.

N.A.-Not available.

Reference: Report No. TR 13 Division of Oil \& Gas 


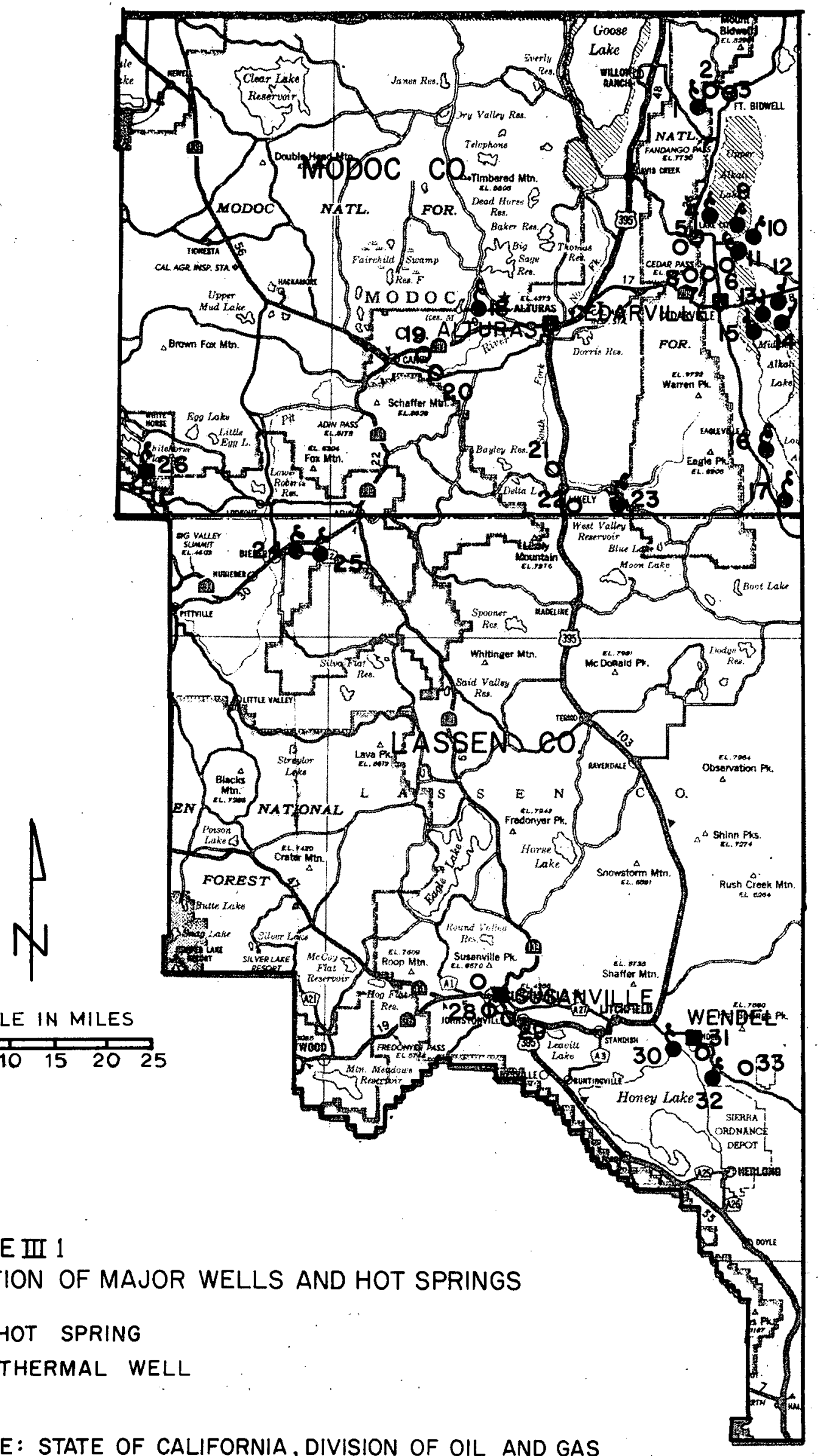

SOURCE: STATE OF CALIFORNIA, DIVISION OF OIL AND GAS TECHNICAL REPORT 15 


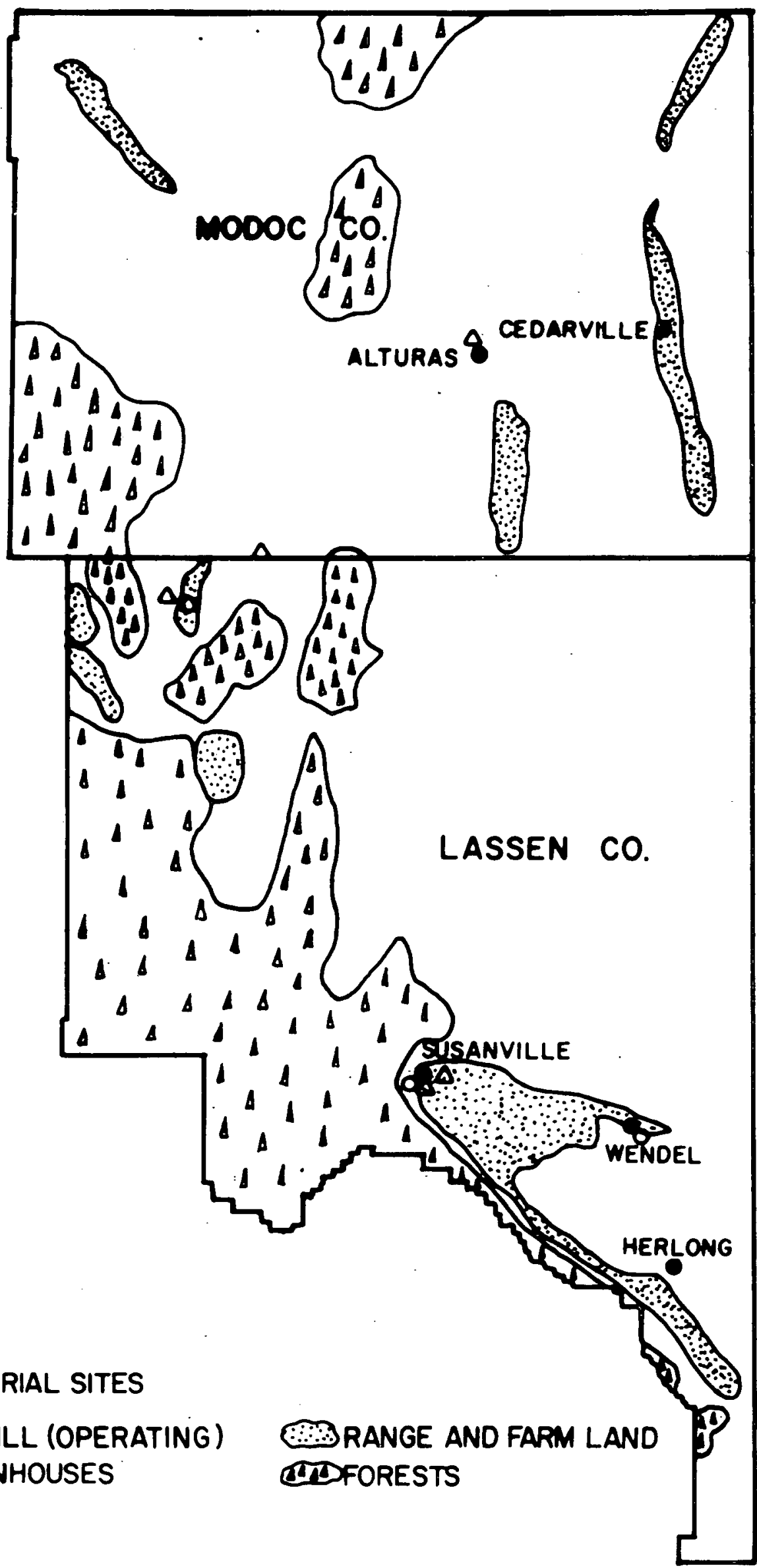

FIGURE III-2

MAJOR INDUSTRIAL SITES

$\triangle$ SAWMILL (OPERATING) BRANGE AND FARM LAND O GREENHOUSES COFORESTS 


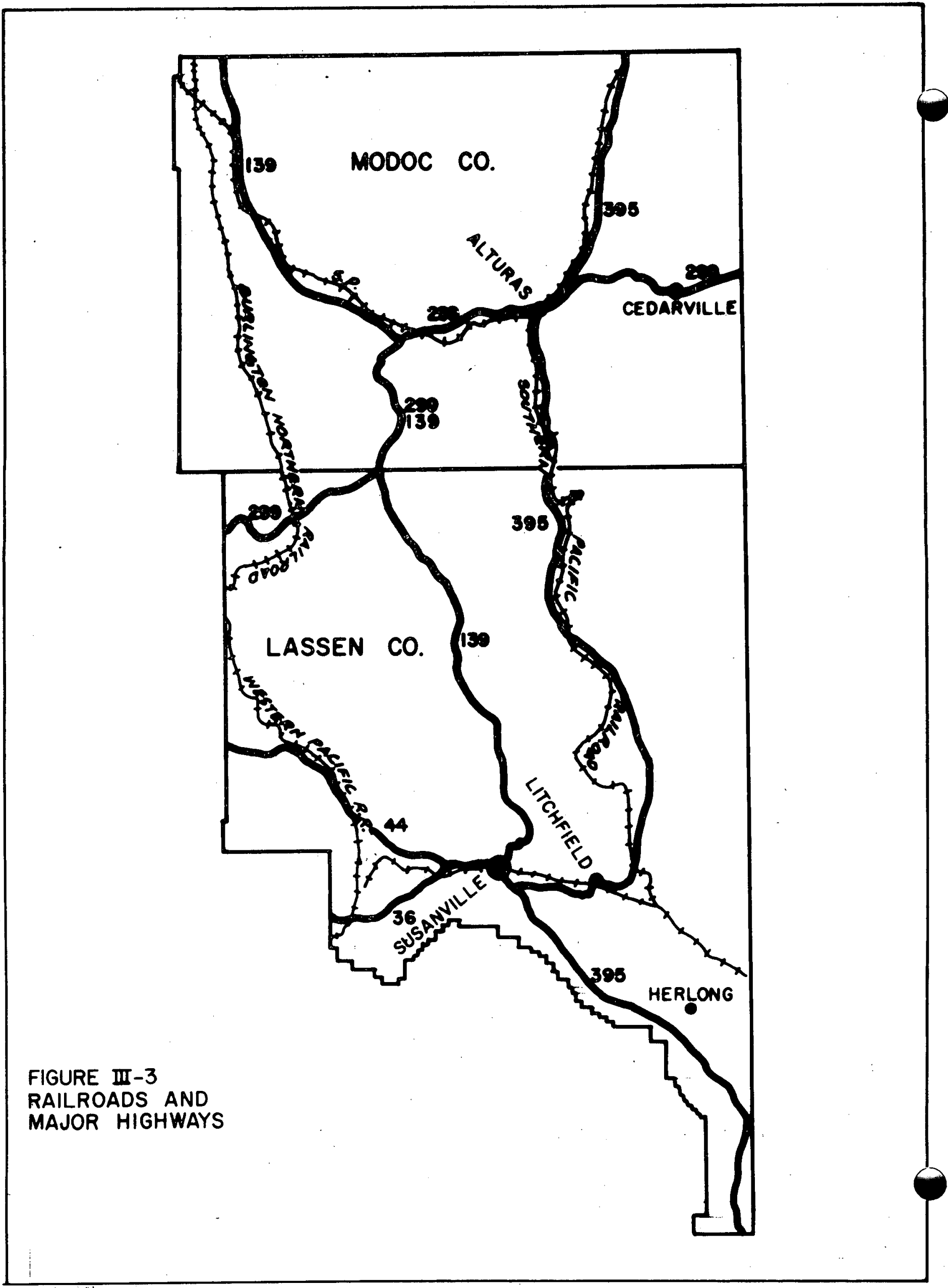




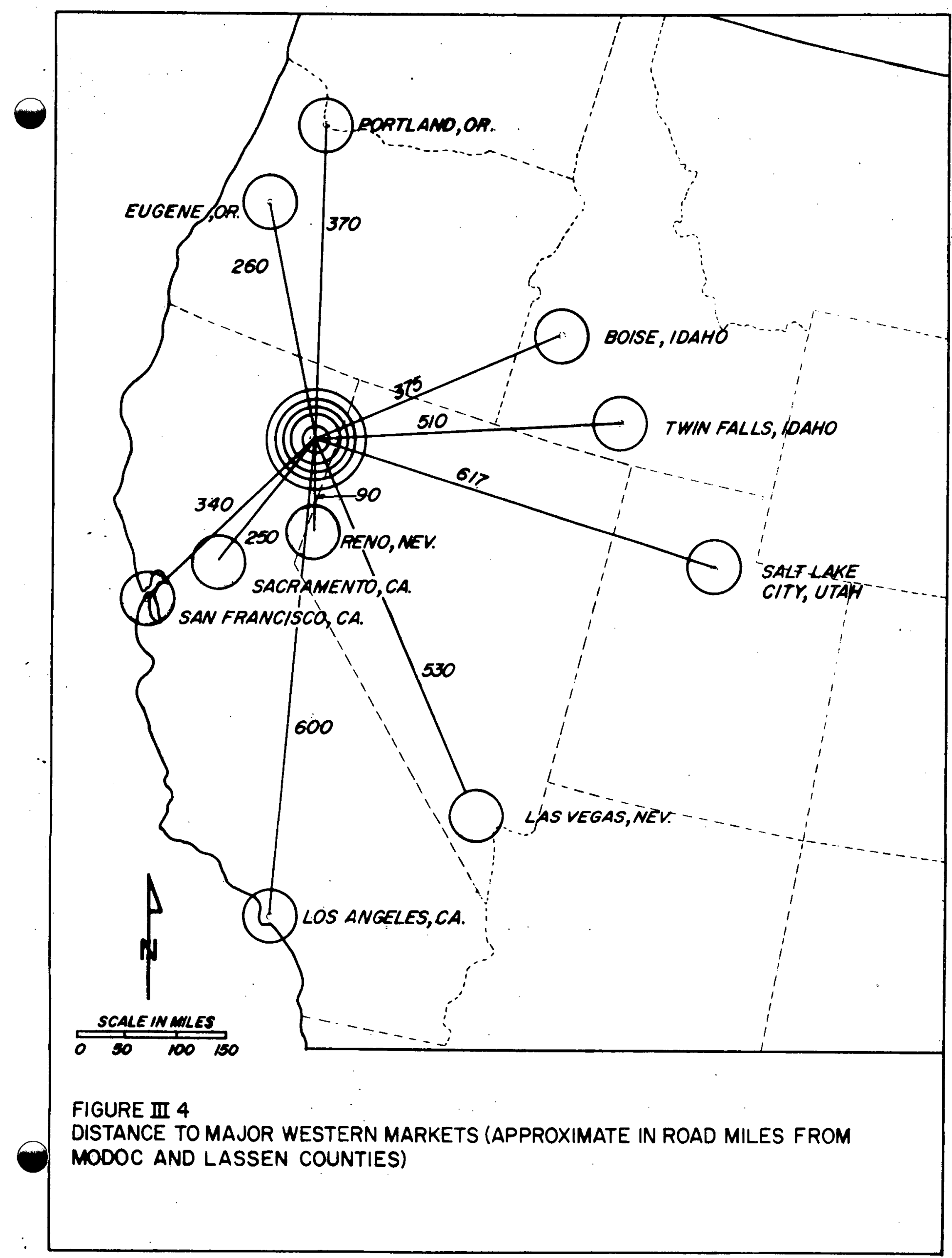




\section{Influence Factors and Other Sources of Energy}

of the 14 influence factors, several can be discussed as generalizations covering all the applications, while others are quite spectfic to each. This section provides a general discussion for the area in relatton to the influence factors shown on page 31 .

\section{a. Climate}

Climatic summarles for the princtpal geothermal areas in Modoc and Lassen Counties are provided in the appendix. All three areas have simtlar cltmates, with Alturas slightly colder than Cedarville and Susanville. Growting seasons are short, indicative of the severe climate of the region. Length of the mean growing season between the last spring occurrence of $32^{\circ} \mathrm{F}$ and the first fall occurrence of $32^{\circ} \mathrm{F}$ ranges between 82 and 131 days for Alturas and Cedarvi1le, respectively. Freezing temperatures have occurred in all months of record for each station. Rainfall is moderate to low, averaging between 12 and 15 inches for these stations.

\section{b. Fresh Water Supply}

Presented below is an evaluation of the avallabllity of water supplies in the several geothermal areas of Modoc and Lassen Counttes for industrial uses. Potable groundwater occurs in Surprise Valley, P†t River Valley (near Alturas), Big Valley and Honey Lake Valley. For all practical purposes industrial water supplies will either be developed from local groundwater or purchased from community systems. This section provides a brtef evaluation of the avatiability of groundwater in the study area.

\section{SURPRISE VALLEY}

Surprise Valley is a closed elongated valley, 50 miles long by about 12 miles wide. Since the valley has no surface outlet, sal tne intermittent lakes have formed throughout most of its length in the central, lower elevation areas of the basin. Groundwater occurs along the alluvtal bajada of Warner Mountains to the west, and appears near the surface in many lower elevation areas. In many places along this western flank, the piezometric surface of confined aquifers is above the surface. Near most of the communttles good areas exist for groundwater development, although there are certain areas with poor water quality--many created by mixing and pollution by thermal springs.

The principal water-bearing formations are the nearmshore deposits, which occur as highly permeable terraces, beaches, spits and de7tas formed in ancient Surprise Lake. Recent valley sediments include alluvial fans, intermediate alluvium and basin deposits. Alluvial fans may reach thicknesses of greater than 1000 feet in the western flanks of the valley. These fans are the principal aquifers of the region.

Water quality is highly variable, ranging from potable quality waters to inferior quality water satisfactory for industrial use only. The latter waters are associated with areas of thermal artesian waters. Water in the study region is far superior in dissolved solids and potentfally troublesome constituents than geothermal water in the Imperial Valley. 
Evaluation of groundwater avatrabiltty and qualtty is site dependent in the valley. Consequently, further determtnatton of avallable water suppltes can be made only after siting of the industrtal plant is made. Generally, however, ample, good quality groundwater is avatlable throughout most of the valley.

\section{PIT RIVER VALLEY}

The Alturas Groundwater Basin, near Alturas and within the Pit River Valley, has a complex geologic history. Prior to the late Miocene uplift which produced the Warner Mountains, the area was occupied by a broad valley, with a large interior lake. This valley received sediments from the adjacent mountains, now composing a portion of the lower member of the Alturas Formation. During the Pliocene and early Pleistocene periods, volcanic eruptions deposited a variety of materials in the basin. Subsequent quiescent periods were followed by formation of a second large lake. Contemporaneous and subsequent faulting, folding and erosion formed the present Alturas Basin.

Principal groundwater zones are (1) Plio-Pleistocene and Pleistocene Lava Flows, and (2) Alturas Formation. Other zones where groundwater occurs include near-shore deposits of the ancient lakes and Recent, al though thin, valley sediments. The Alturas Formation is the major zone of groundwater development. The formation consists of moderately consolidated, flat-lying beds of tuff, ashy sandstone, diatomite and basalt. Buried lava flows in the Alturas Formation may account for a large proportion of water yielded to wells. Substantial volumes of groundwater have been estimated to exist in storage in this basin. Water quality is generally good and suitable for more beneficlal uses. However, in large areas in the Warm Springs Valley subbasin, groundwaters have excessive sodium absorption ratios and are considered hazardous for irrigation use.

\section{BIG VALLEY}

Big Valley is situated in the southwestern corner of Modoc County, extending into the northwestern corner of Lassen County. Principal water bearing formations in the region are Pliocene to Pleistocene Lava Flows, the Bieber Formation (lake deposits, sands, silts and clays) and recent valley sediments. Lavas in the basin consist of jointed and fractured basalt, and are generally moderately to highly permeable. These lavas exist in irregular patterns, and are limiting from groundwater development except as they are encountered in the Bieber Formation. The Bieber Formation is estimated to reach thicknesses of at least 1000 feet, and in areas may be as great as 2000 feet. Principal aquifers in the formation are beds of white pumiceous sand and black volcanic sand.

Recent valley sediments include basin deposits and alluvium. Basin deposits are low in permeability and do not yield much water to wells. Alluvial fans occur only in a few areas. Both these deposits are unimportant from a water supply standpoint in the basin; however, local areas may yield moderate supplies of water. The intermediate alluvium consists of deposits of about 200 feet in thickness. Where found in sufficient thickness, these materials may yield large quantities of water to wells. Most wells developed in the Big Valley Basin yielded between 190 and $900 \mathrm{gpm}$, with significant drawdown, indicating a specific capacity and low permeability. Competing uses include present irrigation demands. Groundwater in this basin is generally excellent in quality and suitable for most uses. 
The sediments which comprise the Honey Lake Valley Bas in are relatively deep and contain a substantial volume of groundwater. Sedtments have been derived from erosional products of the surrounding mountains and volcanic intrusions of basalt and other materials. Depositton of coarser materlals has occurred near the point of departure of streams from the mountatns with gradation of finer materlals down-gradient finally associating with the clays and fine silts and salts of lake environments. Over the 500 square mile extent of the Honey Lake Valley groundwater basin saturated sediments are 10-750 feet thick containing an estimated storage of 16,000,000 acre feet. Recharge occurs from channel percolation, bank overflow and direct prectpttation infiltration in the higher elevations, especially on highly fractured and jofnted basaltic rocks in the upper Susan River system.

Apparently, under normal conditions the Susan River in the valley area east of Susanville is an effluent stream, i.e., the river receives tts base flow from groundwater. The basin generally acts as a free water table, but in places some confining zones exist. Flowing wells located along the southwestern flanks of the Diamond Mountains tap conftned aquifers in the lower portions of alluvial fans and adjoining shore deposits. Springs in Honey Lake Valley are divided into three groups: those which issue from jointed or fractured rock (generaliy volcanics), thermal springs issuing from deeper origins along or near fautts, and those which issue at the intersection of groundwater with the ground surface.

Groundwater quality varies throughout the area, generally becoming poorer in the lower portions of the basin, especially near Honey Lake. Near Hot Springs, groundwater is generally more highly mineralized. In these areas excessive fluoride, arsenic, and boron are sometimes present.

\section{c. Markets and Shipping}

Most applications for geothermal energy, to be commercially economical, require relatively large scale operation and sizeable markets. The reasons for this are tied both to the normal business activities and to incorporation of geothermal energy. Business activities tend to optimize for large operations because labor can be used more efficiently, more mechanization is affordable, overhead can be spread more effectively, and marketing and shipping can take advantage of reduced costs. Geothermal energy is also more effectively used by a large enterprise because the cost of drilling and distributing the water is high and the quantity of energy available even from a single well is normally far in excess of that which a small business can efficiently absorb.

Distances from Susanville and Alturas to some selected major markets are listed below (See Figure III-4 page 12):

\section{MARKET DISTANCES}

Market

Reno, Nevada

Sacramento, California

San Francisco, California

Eugene, Oregon
Distance From

Susanville (miles)

80

229

318

435
Distance From

Alturas (miles)

188

337

426

290 
Truck routes to the markets are adequate and kept open most of the year. Costs of transportation by truck in California, including loading and unloading, run in the range 0.15 to 0.45 cents per pound per 100 miles for a wide range of products. Costs for shipment by raily average 2.1 cents per ton mile. This equates to about 0.1 cent per pound per $100 \mathrm{miles}$. When all other factors are essentially equal, i.e., capttal, labor costs, taxes, etc, location of a business enterprise near a geothermal area becomes economical when the savings in energy exceeds the added cost for transportation of supplies and produce. As will be seen in the text, the savings in cost of energy does, in fact, exceed transportation costs for several of the selected products.

\section{d. Labor Supply}

The major source: of labor in Lassen County is Susanville, which has an unemployment rate greater than 20 percent peak and 17 percent annual average. Unemployment is highly seasonal, with wide swings between high summer and low winter employment. Over 50 percent of the employment is through government jobs and perafamily income is about 75 percent of the state average.

Modoc County unemployment also fluctuates widely, from 17.3. percent in January to 8.8 percent in May 1976.

Appendix A provides descriptive material and Tables which define specific skills of the labor force.

\section{e. Environmental Considerations}

The development of a geothermal energy supported industry in Modoc and Lassen Counties would lead to certain environmental impacts. These impacts can be divided into those which would be caused by the geothermal energy system and by those which would be caused by the remaining elements of the industrial plant. Industrial applications that: have been considered in this study are those that would utilize energy from geothermal waters through closed heat transfer systems. The geothermal fluid cycle proposed is a one-pass systemextraction, energy conversion and re-injection. Under operations of this nature, impacts of importance are those related to geophysical and hydrological considerations. Air quality impacts would not be a consideration, since the energy systems proposed would be closed to the atmosphere. An examination of the potential geothermal energy cycle environmental impacts is provided.

Environmental impacts from the geothermal energy system may occur during drilling, site development and utilization stages. Initial impacts from drilling and site development can arise from land surface disturbances (hydrographic and ecologic disturbances). Site-related impacts that may be most important in Modoc and Lassen Counties are possible critical habitat and archaeologic disturbances, if development sites are not wisely located. Surface water and air quality impacts during drilling and site development will be light, both related to brush removal and baring. of the land surface (erosion and dust problems), which will be small in scale relative to other natural factors.

Critical wildlife habitat in the region includes (1) sage grouse strutting grounds, (2) antelope kidding grounds, (3) deer and antelope wintering areas, 
and (4) habitats for critical rare and endangered species including marten, wolverine and fisher: Careful planning programs can help to mitigate most potential impacts of this nature."

Geothermal energy utilization systems proposed are one-pass, closed systems (extraction, heat transfer and re-injection). Impacts of possible concern are those associated from fluid extraction and re-injection processes to the reservoir, and transit through potable groundwater aquifers. The possible causes of these types of impacts are related to the following:

- Pressure Changes in the Hydrothermal System

- Rock/Sediment Internal Stress Changes

- Tectonic Readjustments

- Erosion/Abrasion of Producing Components

- Dissolution of Conforming Rocks and Sediments

- Precipitation of Solutes

- Water Quality and Balance Alterations

Impacts that are often addressed to withdrawal and injection of geothermal fluids are: (1) induced seismictty, (2) land deformation, and (3) shallow groundwater quality degradation.

The methods proposed for utilization of geothermal energy are non-consumptive, meaning that depletion of the fluid would not occur. "Therefore, what is extracted from a point "A" is re-injected at some point "B", theoretically 1ocated such that the injected water does not adversely affect the hydrothermal reservoir system. If this closed system has hydraulic continuity, land deformation would not occur, and in all practicality, seismic effects also would not be anticipated. However, if the location of points $A$ and $B$ are not directly linked hydraulically, and differential hydrostatic pressure responses occur, localized deformation may occur at the zone of extraction (i.e., recharge to the zone of extraction is less than the withdrawal rate). If re-injection must take place at high pressures, seismic considerations become very important. A discussion on subsidence is provided in the following section.

However, since low temperature geothermal wells are generally shallow (less than 1,500 feet), and in unconsolidated basins, seismic considerations would normally be minimal.

\section{INDUSTRIAL APPLICATIONS}

Development of new industry in Modoc and Lassen Counties will create a variety of effects. Most will be beneficial, such as providing new jobs and income in economically depressed areas; however, with every action of man there are some adverse environmental effects. The purpose of this brief section is to address the various types of adverse environmental impacts that may occur with new industrial activities as studied in this report. Mitigation of principal impacts has also been addressed. 
Greenhouses:

Environmental impacts that may be associated with greenhouses are much the same as any agricultural activity. Land is required, fertilizers and pesticides are applied, crop wastes must be disposed of, water for irrigation is necessary, and materials for construction are required. Each greenhouse may differ from another. Crops may be planted in native soil, or in closed hydroponic furrows with gravel, or other sub-base materials. In one case, infiltration into the ground may occur, and in the other, little or no infiltration would result. These types of impacts are localized, and do not emerge until many years after, in the form of localized groundwater degradation--true of most agricultural areas of the world.

Plant residue wastes after cropping are disposed of in conventional manners. Secondary recovery of these wastes can be possible through composting and/or pyrolitic conversion.

Aquaculture

The controlled growth of aquatic animals in geothermally heated ponds will cause certain localized environmental impacts. Land is required, substantial water is necessary, occasional odors may result, and possible water pollution may occur.

\section{Cattle Feeding}

Cattle feedlots may cause substantial adverse impacts if improperly constructed and maintained. In this case, considerable land is required, odors and air quality (hydrocarbons) degradation may occur, and water pollution may be severe, due to the concentration of several thousand animals. Waste conversion and/or disposal of manure is also a significant consideration.

Onion Dehydration

Adverse impacts that may be associated with onion dehydration $\mathrm{plants}$ include 1 and requirements, possible odor problems, and necessary waste disposal.

Kiln Dry Lumber

Existing drying units would be converted to utilize geothermal energy. No new impacts would occur outside of: minor construction-related considerations.

SUBSIDENCE CONSIDERATIONS

Subsidence, the lowering of the land surface, can be caused by sub-surface extractions of water accompanied by a pressure decline. Saturated sediments, and some rocks, are supported in part by the water matrix. When this fluid support is removed, the over-burden sediment weight may be sufficient to cause compression of the formation voided of fluid. Whether compression occurs or not, and to what extent, is dependent upon (i) the compressive strength of the formation, and (2) absolute pressure head decline that occurs.

There have been many subsidence occurrences of significant extent in groundwater, oil and geothermal production fields. In groundwater and geothermal 
fields (Wairakei, New. Zealand), subsidence has been associated with lowering. of the water-table and compaction of unconsolidated sediments after removal of large volumes of water. Lateral deformation may also result due to induced steep hydrautic gradients (Lofgren, 1974).

Subsidence in groundwater basins where substantial fluid has been withdrawn, such as the San Joaquin Valley, have reached declines of 29 feet. In Wairakei, New Zealand, where large amounts of geothermal fluids have been withdrawn without re-injection of the waste stream to the reservoir, up to 30 feet of subsidence has occurred, effecting more than 25 square miles, with the maximum subsidence occurring beyond the production fields.

When the water-table is not lowered and the producing formation is competent, i.e., it will resist compression from the weight of overlying formations after pore water is removed, subsidence will not occur.

It appears that in Ladere110, Italy and The Geysers, the host steam formation is competent, since no or only very slight subsidence has occurred during more than 60 years of operation at the former, and more than 16 years of operation at the latter.

In. the Susanville-Honey Lake Valley region, the producing geothermal reservoir proposed for development is situated above bedrock in andesite, a zone of hypothesized high porosity and permeability roughly 3,000 feet of andesite are overlain by confining lacustrine deposits consisting of clay zones and unconsolidated alluvium deposits.

Extraction of fluids from the lower portions of the andesitic formation might not cause subsidence even with depletion of the water source and lowering of the producing zone pressure head (Zebal, 1976).

The hypothesis that subsidence will not occur is based upon the competency of the andesite to withstand strain deformation under actual overburden loads. Operations for geothermal energy conversion systems investigated in this project would involve extraction and reinjection to the host formation, but sufficiently distant from the producing reservoir so as not to cool (degrade) the reservoir, yet close enough to provide for recharge continuity to the area of the reservoir.

Another consideration when monitoring of subsidence is to be undertaken, is the relative effect of other groundwater pumping in the locality (for irrigation, etc.).

Since local groundwater production in the region has been increasing, it is probable that with further removal of groundwater and lowering of water tables, some subsidence will occur in several areas if it has not already.

Subsidence associated with valley-wide shallow groundwater pumping and deep geothermal fluid extraction may be indistinguishable from one another without elaborate monitoring systems. How the two subsiding zones would interact is comparis on to shallow groundwater volumes extracted. The relationship between the relative amounts of extracted volumes from the reservoirs and subsidence is not known. Assuming that subsidence occurs in direct proporation to the volume of fluids extracted, the subsidence resulting from geothermal fluids, if such should occur, would probably be small in relationship to that which may occur from groundwater pumping for irrigation. 
Surface changes may also result from deep-seated tectonic re-adjustments triggered by stress changes (Lofgren, 1974).

\section{GROUNDWATER DEGRADATION}

Improperly specified materials in geothermal wells may lead to casing leaks, and degradation of surrounding potable groundwater supplies. Quality deterioration would be related to temperature gain, increase in total dissolved solids, and the trace elements--boron, fluoride and arsentc. Proper selection of materfals and proper construction methods would normally minimize this type of impact. Areas of concern are those where potable groundwater reservoirs overlite deep hydrothermal systems.

\section{f. Quality of Geothermal Fluid}

The chemical constituents typical of geothermal water in the areas are shown in Table III-2.

In some wells (samples 1 and 4 in Honey Lake Valley) the water is of high quality and appears to meet the Interim Primary Drinking Water Standards of the U.S. Public Health Service, part of which require dissolved solids to be less than $1000 \mathrm{mg}$ per liter, boron less than $1 \mathrm{mg}$ per liter, and fluorine less than $1.4 \mathrm{mg}$ per 1 tter. Most samples, however, do not meet requirements for human consumption.

Of the five applications for geothermal energy analyzed in this report, four include products for human consumption. Existing public rules governing use of water for this purpose deal mostly with water re-use and disinfection and were not designed for geothermal water. For lack of specific directives, and based on warnings of the potential dangers of concentration of toxic compounds in various plants and organisms by agricultural experts, application of geothermal in this report covers only indirect use for heat in closed piping systems. Heat is extracted from the water through pipe walls without direct contact with the end use product. In one case, this imposes a considerable economic penalty--aquaculture of prawns. Currently, data is being collected through experiments with prawns grown directly in geothermal water 5 at Oregon Institute of Technology, but the quality of the water there is very good. (230 ppm).

Another concern in use of geothermal water is corrosion and deposition of solids. For most chemicals (calcium sulfate being a notable exception) the solubility increases with temperature. The geothermal waters tend to saturate at the higher temperatures. and to precipitate the excess salt as they cool through the process equipment. Calcium is well below its saturation level, and other constituents are in sufficiently low concentrations, that deposition does not appear to be a major concern. Of 11 samples tested ${ }^{3}$ in Honey Lake and Surprise Valley, the $\mathrm{pH}$ was above 7.0 (neutral) in all cases and averaged 8.1 (mildly alkaline). The pH range is ideally suited for low cost materials of construction, i.e., steel asbestos (pipe) with minimum corrosion. That corrosion and scaling are not insuperable impediments to direct geothermal fluid use can be proven by current usage of geothermal water to heat a swimming pool and a greenhouse in Susanville, a second greenhouse near Wendel-Amedee, and to space heat several buildings on the Oregon Institute of Technology (OIT) Campus. 


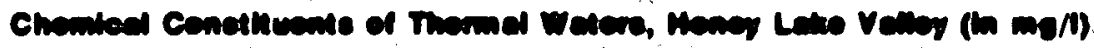

\begin{tabular}{|c|c|c|c|c|c|c|c|c|c|c|c|c|c|c|c|c|}
\hline $\begin{array}{l}\text { Sample } \\
\text { Number }\end{array}$ & Location & $\mathbf{L i}$ & Na & $\mathbf{K}$ & $\mathbf{R b}$ & Mg & $\mathrm{Ca}$ & $: \mathbf{Z n}$ & $F$ & Cl & $\mathrm{HCO}_{3}$ & $\mathrm{CO}_{3}$ & $\mathrm{SO}_{4}$ & $\mathrm{SiO}_{2}$ & $\mathbf{B}$ & Sol \\
\hline 1 & NE/NE Sec. 6 & $<0.01$ & 20 & 3.8 & $<0.01$ & 3.4 & 19 & 0.043 & $<0.1$ & 2.0 & 120 & 1 & 11 & 53 & $<0.02$ & 233 \\
\hline 2 & SE/NE Sec. 6 & 0.05 & 140 & 4.6 & 0.02 & $1: 6$ & 24 & 0.009 & 1.2 & 64 & 68 & 1 & 190 & 62 & 1.4 & 558 \\
\hline 3 & SW/SE Sec. 23 & 0.12 & 280 & 7.5 & 0.04 & $<0.1$ & 18 & 0.015 & 4.1 & 190 & 50. & 1 & 360 & 120 & 5.5 & 1,040 \\
\hline 4 & NE/SW Sec. 30 & 0.01 & 58 & 8.0 & 0.01 & 2.2 & 6.0 & $<0.005$ & 0.2 & 17 & 112 & $i$ & 32 & 42 & 0.22 & 279 \\
\hline 5 & NW/NE Sec. 8 & 0.08 & 250 & 5.5 & 0.02 & $<0.1$ & 14. & $<0.005$ & 4.4 & 160 & 44 & 2 & 300 & 95 & 4.0 & 879 \\
\hline
\end{tabular}

\section{MODOC COUNTY}

Chemical Constltuents of Thermal Waters, surprise Valley (In mg/l)

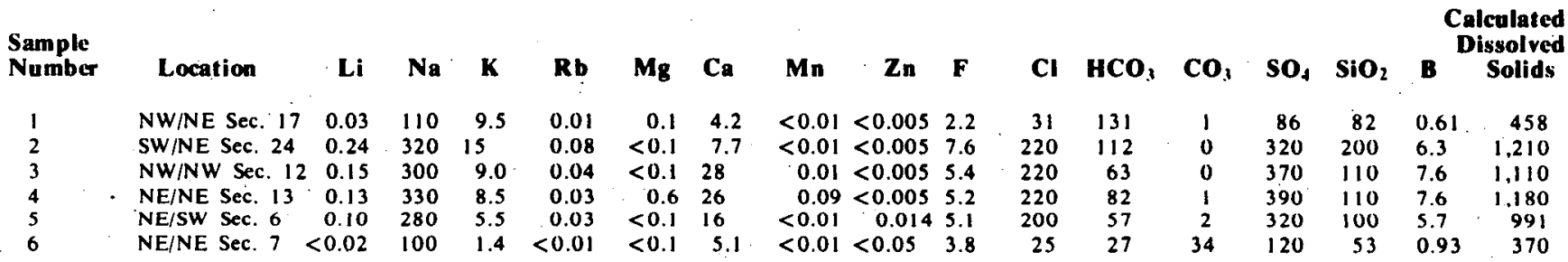

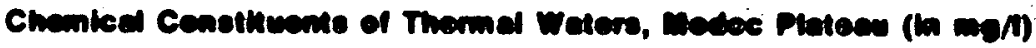

Samplo
Number
1
2
3
4
5
6
7

$\begin{array}{lrrrr}\text { Location } & \text { Li } & \text { Na } & \text { K } & \text { Rb } \\ \text { NE/NW Sec. 29 } & 0.15 & 250 & 6.5 & 0.02 \\ \text { SW/NW Sec. 31 } & <0.01 & 49 & 3.4 & <0.01 \\ \text { NW/SW Sec. 9 } & 0.17 & 230 & 5.2 & 0.02 \\ \text { NW/NE Sec. 29 } & 0.40 & 330 & 11 & 0.06 \\ \text { NW/SE Sec. 12 } & 0.10 & 220 & 3.2 & 0.01 \\ \text { SW/SE Sec. 15 } & 0.12 & 240 & 5.9 & 0.02 \\ \text { NW/SW Sec. 25 } & 0.12 & 300 & 4.3 & 0.02\end{array}$

$\begin{array}{rr}\text { Mg } & \text { Ca } \\ <0.1 & 20 \\ <0.1 & 4.2 \\ 0.2 & 44 \\ <0.1 & 19 \\ <0.1 & 30 \\ <0.1 & 30 \\ <0.1 & 52\end{array}$

$\begin{array}{cc}M n & \text { F } \\ <0.01 & 2.1 \\ <0.01 & 0.4 \\ 0.01 & 1.9 \\ 0.012 & 4.0 \\ <0.01 & 2.0 \\ <0.01 & 2.6 \\ <0.01 & 3.6\end{array}$

CI $\mathrm{HCO}_{3} \mathrm{CO}_{3}$

$\mathrm{SO}_{4} \mathrm{SiO}_{2}$

Calculated

Dissolved

Constituents Below Detection:

Cs $<0.1$

$\mathrm{Fc}<0.06$

Cd $<0: 01$

(i) $<0.05$

$\mathrm{Cu}<0.02$

$\mathrm{Ni}<0.04$

$\mathrm{Pb}<0.1$

$\mathrm{Zn}<0.005$

I Chemical analyses by L., M. Willey, T. S. Presser, J. B. Rapp, and M. J. Reed.

Data from DOG Report No. TR15, Chemistry of Thermal Water in Selected Geothermal Areas of California, by Marshall J. Reed 
$\mathrm{OIT}^{27}$ is currently running corrosive tests on various specimens located above at the waterline and immersed in geothermal well water.

Generally, water under $100^{\circ} \mathrm{C}$ will not depos $1 \frac{5}{8}$ silifates, and high'chloride content will enhance corrosion of carbon steels 28 . It is difficult to predict corrosivity, however, based on simple chemtcal analyses. Work at Reykjavik, Iceland, indicated that corrosion rates of geothermal waters with similar chemical analyses could vary widely. Reasons for the vartation are not understood. Pending specific corrosion data for the study areas, it has been assumed that common matertals of construction in current use will suffice.

\section{g. Multi-Use}

Multi-use can be made practical where several users are clustered together in an industrial park. Residual energy in the water discharge from a high temperature system can be consumed by downstream low temperature users. A food processing plant could discharge its water to a greenhouse which might in turn discharge to a space heating system, to a feed lot heating system or to a fish pond.

Multi-use requires fewer wells and provides the most efficient use of the geothermal resource but a penalty must be paid in the cost of user equipment. Because it places the users in series, designs must include by-passes, cold water mixing controls and/or automatic throttling controls to prevent upstream process fluctuations from causing temperature changes in water fed to downstream users Also because the thermal driving force is less, the heat exchangers in the downstream applications must be larger. Multi-use is economical when the savings in wells and distribution systems exceed the added user equipment costs.

\section{h. Other Sources of Energy}

The four principal sources of energy which are available within the study area are electrical power, LPG, fuel oil and wood. There is no natural gas available, and accordingly, the cost of energy is high.

Electrical power for Lassen and Modoc counties appears to be ample for the present but it is subject to periodic winter blackouts, the transmission and switching problems occur. Neither county generates its own power. Lassen County is supplied by R.E.A. and Pacific Gas and Electric Company. It is distributed by California Pacific Utility and by the Plumas Sierra Rural Electric Company. Since Plumas Sierra is a cooperative chartered under the. R.E.A., its customers enjoy a significant rate advantage of the private utility customers. This is due to the fact that C.P.U. must purchase bulk power from P.G. and E., while Plumas Sierra uses Bureau of Reclamation, Feather River or Bonneville power, "wheeled" over P.G. and E. transmission lines at a modest cost. Modoc County is served by Pacific Power and Light and Surprise Valley Electrification Corporation.

Fuel oil is a second source of energy, and is consumed in boilers in large facilities such as the Conservation Center near Susanvilie and for general space heating. LPG is also used for space heating primarily in rural areas.

Due to the high cost of other energy sources, a considerable amount of wood is consumed for residential and industrial purposes. Both Eagle Lake Lumber Company and Coin Lumber Company produce all of their process steam from sawdust and planing chips. In addition, the Eagle Lake Lumber Company has some 6,000 KW of electrical generating capacity. 


\section{SELECTION OF APPLICATIONS}

In evaluating job potentials of various applifcations this study analyzed several energy intensive industries that could utflize inexpens lye?geothermal energy to reduce product costs, and estimated the magnitude of potential competitive advantages. Selection of the candidate applications was achieved in conjunction with field trips to the geothermal areas, interviews with local entrepreneurs and owners of wells, and discussion of details of business operations with experts in the field--both at universities and in business operations. Because the major employment businesses endemic to Lassen and Modoc counties are cattle ranching, agriculture and lumbering, the field of applications was initially narrowed to ten which appeared to fit these categories.

They were:

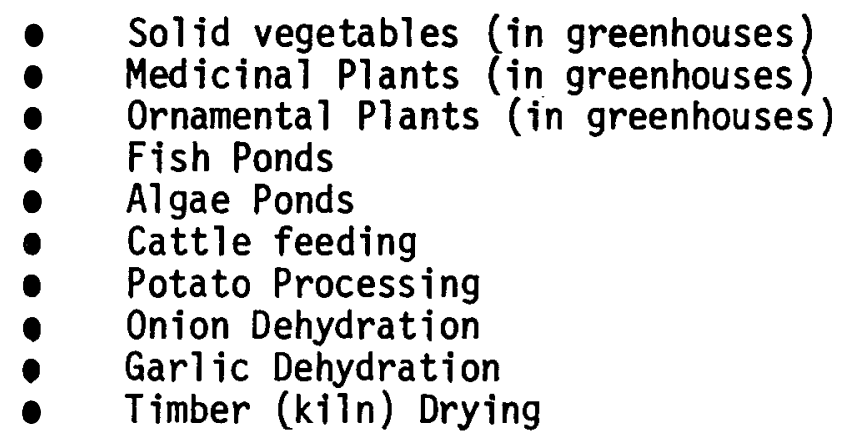

On further detailed analysis of potato processing it was determined that while substantial savings would accrue by use of high temperature geothermal water up to $350^{\circ} \mathrm{F}$, only insignificant savings $(0,1-0.2$ cents per pound) could be attained through use of water at less than $212^{\circ} \mathrm{F}$.

\section{POTATO PROCESSING}

\begin{tabular}{|c|c|c|c|c|}
\hline Process & $\begin{array}{c}\text { Temperature } \\
{ }_{\circ} \mathrm{F}\end{array}$ & $\begin{array}{l}\text { BTU/1b } \\
\text { Product }\end{array}$ & $\begin{array}{l}\text { *Heat Cost } \\
\$ / 1 \mathrm{~b} \text { Product }\end{array}$ & $\begin{array}{l}\text { Use of Low Temperature } \\
\text { Geothermal Energy }\end{array}$ \\
\hline $\begin{array}{l}\text { Peeling } \\
\text { Blanching } \\
\text { Cooking } \\
\text { Flakes } \\
\text { Flour } \\
\text { Granulating } \\
\text { Slices }\end{array}$ & $\begin{array}{l}180 \\
180 \\
212 \\
350 \\
350 \\
550 \\
230\end{array}$ & $\begin{array}{r}875 \\
1250 \\
1000 \\
8409 \\
8409 \\
5500 \\
7500\end{array}$ & $\begin{array}{r}.23 \\
.33 \\
. .27 \\
2.23 \\
2.23 \\
1.47 \\
2.00\end{array}$ & $\begin{array}{l}\text { Yes } \\
\text { Yes } \\
\text { No } \\
\text { No } \\
\text { No } \\
\text { No } \\
\text { No }\end{array}$ \\
\hline
\end{tabular}

*Use of gas (efficiency $60 \%$ )

As a consequence, potato processing was deleted and onion dehydration substituted.

It will also be of interest to note several applications which were considered and rejected as being less practical than those selected. Table IV-1 lists these reasons for discontinuing study. 


\section{REJECTED APPLICATION STUDIES}

\section{Application}

1. Medicinal Plants (Greenhouse)
2. Poultry

3. Swine

4. Catfish

5. Carp

6. Singel Celled Protein
Reason for Rejection

Lack of Economical Data

Fuel costs per bird are not a significant cost factor, i.e., 0.43 cents per pound.

Industry concentrated in east where grain, molasses and hominy are available. Young need environmental control but problems with adults are associated with too much heat rather than too little.

Lack of proven market in western U.S.A. Failure rate is 75 percent among new businesses.

Easy to grow at high densities but considered an inferior food fish by the American public.

Most concentrated protein source and great future potential potential but development of market too uncertain for purposes of this report.

One application of low temperature geothermal energy which has received insufficient attention and which needs more study in future geothermal energy studies is space heating. Where shallow wells or springs are available immediately adjacent to a home, installing a simple economical piping system can be made to supplement or replace the normal home heating systems. One rancher in the Surprise Valley area is in the process of doing just this. Also in this same locale, the Mineral Springs Motel (currently old and in disrepair) at one time heated its buildings and its large swimming pool using an adjacent spring. Its new owner is considering renovating and rebuilding the geotherma: heating systems. The Susanville Geothermal Energy Project Study analyzed geothermal utilities for distributing hot water over long distances to agricultural and industrial users. The economics of the system were sensitive to the spacing of the users and the use quantities. With current fossil fuel prices, use of such a utility to heat individual homes in small towns would be uneconomical. Larger buildings spaced reasonably close to each other appear to be more practical. In Klamath Falls, more than $1,000,000$ square feet of buildings spread over the campus of Oregon Institute of Technology are geothermally heated. The Presbyterian Intercormunity Hospital $(96,000$ square feet) has added geothermal space heating to assure an uninterruptable energy supply, and space heating for several churches is under consideration. It is also of interest that geothermal water can be feasibly transported long distances with only moderate: losses in temperature. 
The economics of space heating using geothermal water and long distance transportation are two subjects that should be Anvestigated more thoroughly. However, due to the lack of job intensity and dispersion of potential users,. space heating was discarded as being unpromising for this particular study.

The final selection of applications and the reasons for their selection are as follows:

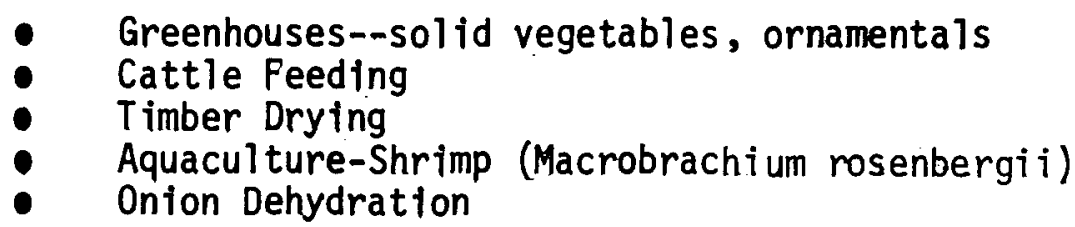

Greenhousing is an obvious selection. The sciences of greenhouse design, heating requirements, control of crop pests, crop nourishment and marketing are all well known factors. The cost of heating is very similar for wide varieties of crops. This enables comparison of many agricultural applications with a minimum of analysis. In addition, moderate scale geothermal heating of greenhouses has been practiced in Lassen County for several years.

Cattle feeding was selected because cattle ranching is endemic to the two counties. In Modoc County, where surplus alfalfa is available, cattle are sometimes wintered; but in Lassen County they are shipped out for winter to warmer areas. Because of weak market conditions, cattle ranching is currently in a recession. If geothermal energy could promote wintering in the counties and add to the normal weight gain of the animals, it might contribute to the ability of the ranchers to ride out the recession.

The timber industry is also endemic to both counties and is the only major industry located there. It is highly energy intensive and is a major employer.

Timber drying was selected because it is practiced by the major lumbering corporations and by the smaller sawmills, and because it can be accomplished using low temperature geothermal energy.

Like greenhouses, aquaculture ponds can be used for a wide variety of products, and pond heating analyses can be applied to a wide variety of marine and freshwater organisms. The major obstacle in this study area is the palate of the American public, unaccustomed to consumption of warm water fish such as Talapia and Carp. A large well developed market does exist for shrimp and prawns, however. Market prices are an order of magnitude higher than for the warm water fish. Of the species of this delicacy food available, the Asian fresh water prawn, Macrobracium rosenbergi $i$, is generally conceded to be the most adaptable for controlled breeding, and a large reservoir of research and practical experience is available from Hawai, Japan, U.C. Davis and the Marine Resources Research Institute in Charleston, S.C.

Onion dehyration was selected because of the large quantities of low temperature energy consumed in the process and the existence of a major onion producing area in northwest Modoc County and the Tule Lake area. 


\section{APPLICATIONS}

This section discusses general factors which apply to all the applications and provides an analysis of each application.

\section{A. GENERAL}

\section{Business Considerations}

To appreciate the use of geothermal energy, its costs relative to alternative forms of energy, its effect on profit and its impact relative to other business considerations should be understood.

Costs of geothermal energy are low compared to most other energy sources. The low temperature aquifers lie relatively near the surface so that well drilling expenses are nominal. Energy required for pumping the geothermal water will normally consume only one to two percent of the total energy available in it. Depending on the degree of utilization, the cost of low temperature geothermal energy can range anywhere from $\$ .30$ per million BTU to $\$ 2$ per millition BTU. This compares to aiternate energy sources such as electricity, $\$ 6$ to $\$ 12$, oil about $\$ 3.50$, natural gas, $\$ 1.50$ and propane about $\$ 5.00$ per milliton BTU.

In many cases the savings in energy after allowing for added transportation costs is only a small percentage of the per unit market selling price. Despite this, one should not infer that energy savings in such a situation could not contribute substantially to profit. Consider as an example a product which after a 11 expenses yields a normal profit of 15 percent. Figure $V-1$ illustrates the increase in percent of profit from energy savings. It will be noted that in a case where the energy savings for a 50 cent product is only 2 cents, it can effect a 27 percent increase in profit (see dashed line).

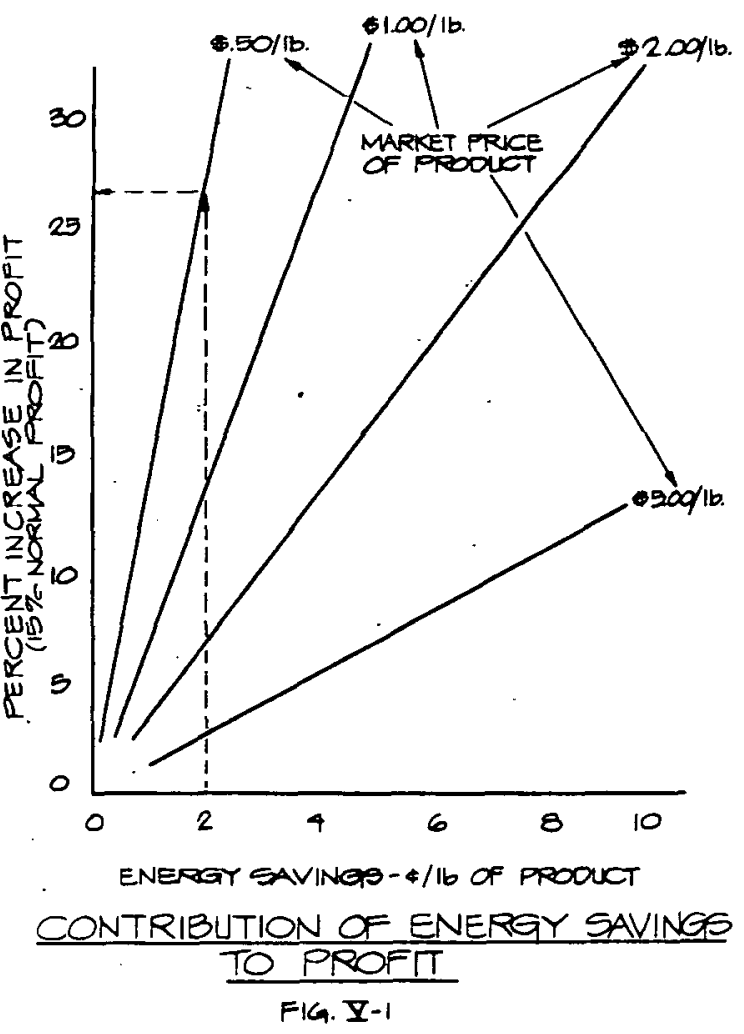


Energy savings through use of geothermal energy can increase the overall efficiency of a process. More important considerations in starting a new business, however, are market price of the product, market stability and capital requirements financing and management ski11s. When a11 the basic elements for a business are favorable, then the secondary impact considerations which boost efficiency can be considered. The mere presence of geothermal energy does not justify an adventure into business. Rather the combination of a favorable business climate, bolstered by this potentially competitive energy source, - can provide an advantageous competitive edge.

\section{Constraints}

The constraints imposed on preparation of this report include a requirement to limit applications to temperatures below the normal boiling point of the geo-: thermal waters at the location in which it is found, about $204^{\circ} \mathrm{F}$ for most $10 \mathrm{ca}$ tions in.Modoc and Lassen Counties. This temperature 1 imit adds a requirement for additional high temperature energy sources for onion drying and for some species of wood in kiln drying. It must not be overlooked, however, that water is available in the area at temperatures to $320^{\circ} \mathrm{F}$. Use of thts higher temperature could provide all the needs of these processes and open up a host of new potential applications, including potato and sugar beet processing, fruit dehydration, refrigeration plants, freeze drying plants, water distiliation plants and others.

\section{Cost of Geothermal Water Systems}

This report deals with a wide variety of products. Similar geothermal water supply and disposal systems will be required by all the applications. This section describes the systems and establishes their costs.

From the criteria outlined in Section II, each we 11 produces $260 \mathrm{gpm}$ through a six-inch casing. To provide the same kind of consistent treatment to the supply and disposal systems, it was assumed that each wel1 would be located 500 feet from the process equipment and that each reinjection we 11 would be located 1000 feet away. Costs were based on casing the entire length of both the supply and reinjection wells. It was also assumed that all systems would require 100 psi pump pressure to meet system pressure drop needs. Real requirements would of course vary; but since pumping power costs were smal1 compared to total costs, the error introduced by the assumption is minor.

Water analyses in the areas showed jt to be alkaline and to contain only dilute concentrations of salts. As a consequence, it appeared that estimates based on carbon steel construction of pumps and asbestos cement for pipes would be practical.

A well driller in the st.udy area described well and pump costs as follows: WELL DRILLING COSTS

\section{Drilling Cost}

Casing Cost

Perforation Cost

Pump,motor w/starter, 260 gpm 20 h.p.

Surface Sanitary Seal
\$1 per inch of diameter/foot of depth (double for rock)

$\$ 7$ per foot for 6 -inch pipe

$\$ 1.50 /$ foot

$\$ 4,000$

$\$ 200$ 
Cost of asbestos cement pipe installed four feet below grade runs about five dollars per foot. To be conservative, it has been assumed that half the well passes through rock, that the perforated length is 50 feet and that the reinjection well is identical to the source well. Based on these considerations and assuming interest of nine percent, 10-year straight 1ine depreciation, and 30 mill per KW power at a mean usage of 25 percent of peak power, capital costs and annual operating costs for a $260 \mathrm{gpm}$ supply and reinfection we1l system were calculated as follows:

$$
\begin{aligned}
& \text { Capital Cost }(\$) \\
& \text { Annual Operating Cost }(\$)=4.87 D+14700
\end{aligned}
$$

Where $D$ is the depth of the supply well in feet.

By combining this data with estimated depths vs. temperature of wells shown in Figure $V-3$ a curve of annual cost vs. well depth and temperature may be prepared as indicated in Figure $V-2$. A shaded area is shown to provide for uncertainties in local prices of equipment, labor and power. The mean costs from this curve are used in the cost analyses of the various applications for the low temperature geothermal energy.

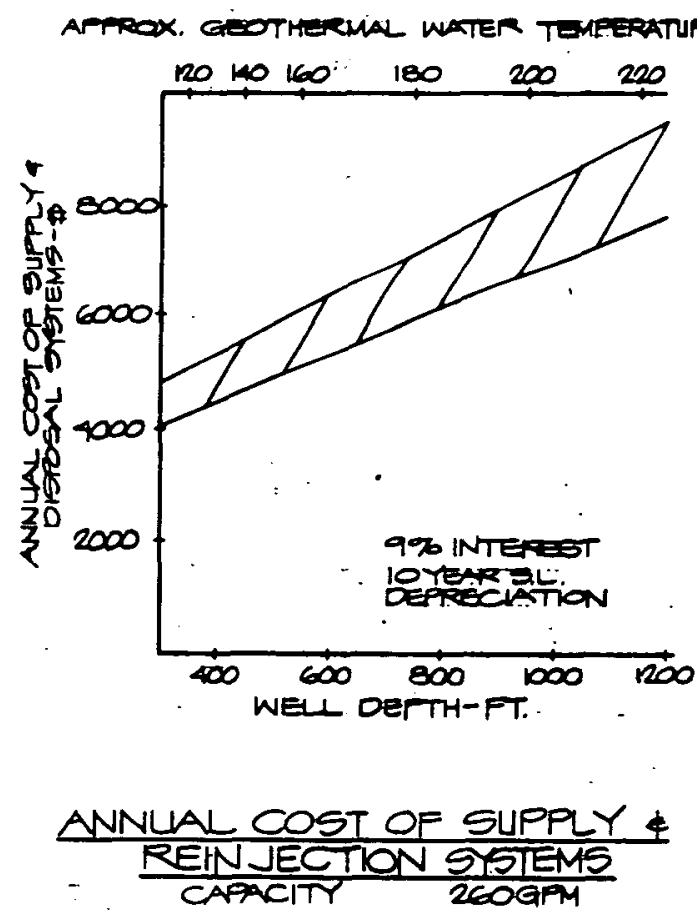

Man. $\mathbf{Y}-2$ 


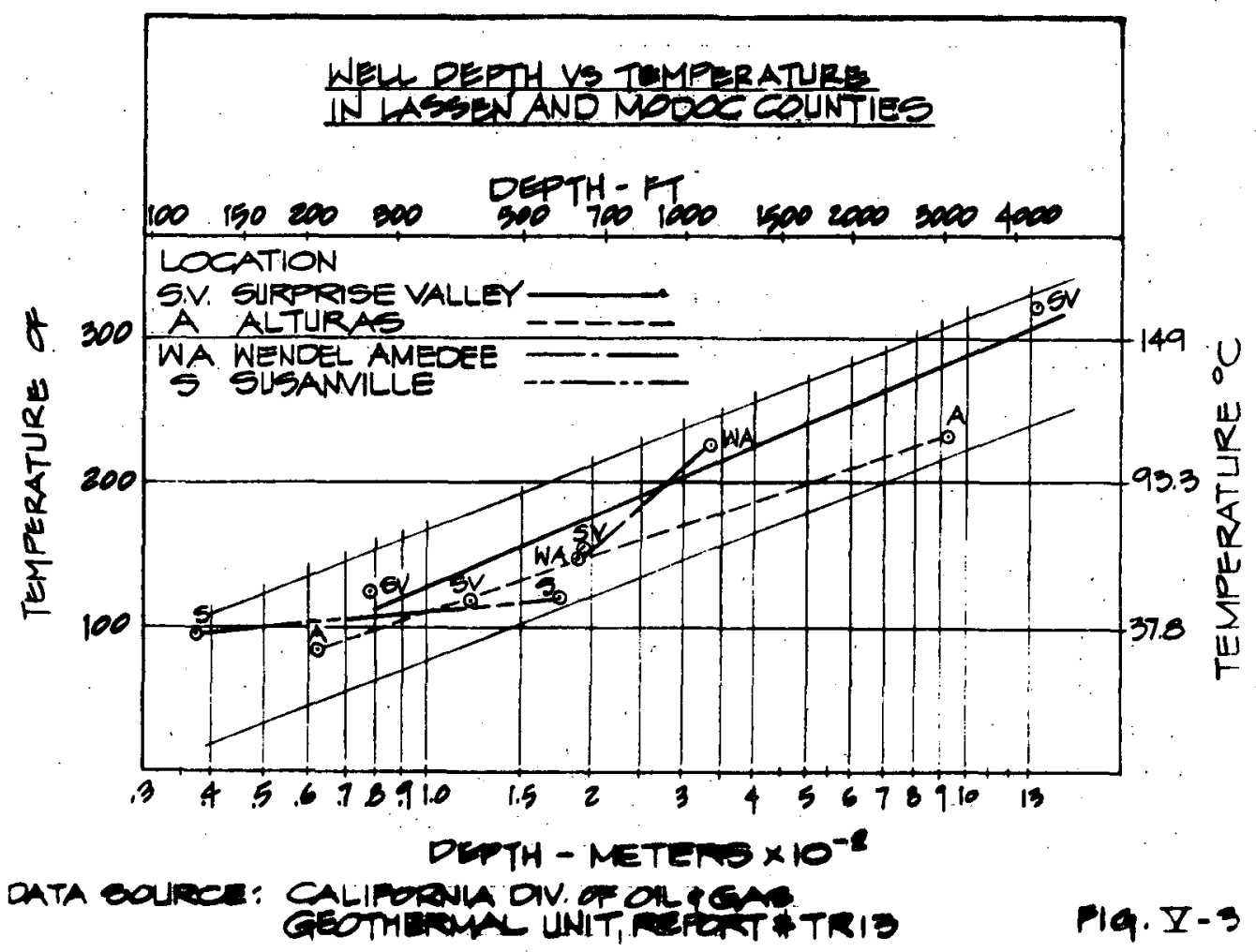

In determing the value to be used for the depth, $D$, a revlew of 11 terature describing the actual resources indicated that the figure of 300 feet provided in the scope should be modified. When well data from $T R-15^{2}$ was rearranged in order of decreasing temperatures, the following list was obtained.

\section{Location and Name of Spring or Well}

1. Well near Lake City *(S.V.)

2. Well (Alturas)

3. Well (W.A.)

4. Well (S.V.)

5. Well (W.A.)

6. Robinson's Well (S.V.)

7. L.D.S. Church We11 (Sus)

8. Hutchen's We1l

9. Roosevelt Swimming Pool (Alturas)

10. New Williams Ranch We11 (Alturaș)
Depth
Ft.

4890

3205

1096

636

620

252

594

407

121

203

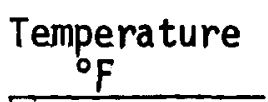

320

230

225

156

147

122

120

118

97

84

*S.V. - Surprise Valley, W.A. - Wendel Amedee, Sus - Susanville

It may be noted that only three wells have temperatures greater than $212^{\circ} \mathrm{F}$ and have depths greatly exceeding the 300 feet. The highest temperature was $122^{\circ} \mathrm{F}$. Obviously, the guideline depth was too shallow. To arrive at a more practical guideline, a graph of log depth temperature was plotted as indicated in Figure $V-3$. This curve provides a weighted average of the available data, and is used estimating the cost of wells for economic analyses in this report.

4. Influence Factor Summary

Influence factors which are of particular importance to the applications are discussed in the text. A summary of each factor effect is illustrated in Table V-1. 
TABLE V-1

SUMMARY OF INFLUENCE FACTOR

\section{EFFECTS ON GEOTHERMAL ENERGY APPLICATIONS}

\begin{tabular}{|c|c|c|c|}
\hline Wfilumen & Ornenhosusing & 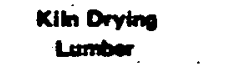 & Fand Lot \\
\hline Cimat & Major tactor in use of energy. & Negligible fector & $\begin{array}{l}\text { Mejor fector in use of } \\
\text { energy. }\end{array}$ \\
\hline $\begin{array}{l}\text { Fresh Water } \\
\text { Requirements }\end{array}$ & $\begin{array}{l}\text { Los than } 1 / 10 \text { of field grown } \\
\text { crops. }\end{array}$ & Naggigible factor & Negfigible factor \\
\hline Shipping & $\begin{array}{l}\text { Truck or railway south to Reno. } \\
\text { Energy sevings excoed trucking } \\
\text { costs. }\end{array}$ & $\begin{array}{l}\text { Existing industry. } \\
\text { Established shipping } \\
\text { costs not affected. }\end{array}$ & $\begin{array}{l}\text { Added production com. } \\
\text { pensates for additional } \\
\text { cost of shipping feed. }\end{array}$ \\
\hline Marketing & $\begin{array}{l}\text { Existing; markets during off. } \\
\text { sasson of field grown product. } \\
\text { Higher market price, better } \\
\text { quality. }\end{array}$ & $\begin{array}{l}\text { Existing industry. not } \\
\text { a factor. }\end{array}$ & $\begin{array}{l}\text { Coop feed lot could put } \\
\text { profit from this element } \\
\text { of marketing into pockets } \\
\text { of hard pressed ranchers. }\end{array}$ \\
\hline Labor & $\begin{array}{l}\text { Most labor affective of applica- } \\
\text { tions. A } 10 \text { acre facility would } \\
\text { need } 30-50 \text { personnel. }\end{array}$ & $\begin{array}{l}\text { No direct change in } \\
\text { labor requirements } \\
\text { between old } \& \text { geo- } \\
\text { thermal mothod of } \\
\text { drying. }\end{array}$ & $\begin{array}{l}18,000 \text { head per year } \\
\text { production requires } \\
10-15 \text { perrons. }\end{array}$ \\
\hline Torrain & $\begin{array}{l}\text { Can be instriled on hillsides } \\
\text { but no leck of flat land in area. }\end{array}$ & Flat terrain preferred & Fbat terrain preforred \\
\hline $\begin{array}{l}\text { Environmental } \\
\text { Considerations }\end{array}$ & $\begin{array}{l}\text { No change to axisting svstems } \\
\text { except reinjection of geother. } \\
\text { mal water. }\end{array}$ & $\begin{array}{l}\text { No changs to existing } \\
\text { systems except rain- } \\
\text { jection of geothermal } \\
\text { water. }\end{array}$ & $\begin{array}{l}\text { No change to existing } \\
\text { systems except rein- } \\
\text { jection of geothermal } \\
\text { water. }\end{array}$ \\
\hline Pesearch & Not required & Not required & $\begin{array}{l}\text { Optimized spacing and } \\
\text { sizing of underground pipe } \\
\text { in particular soik. }\end{array}$ \\
\hline
\end{tabular}

\begin{tabular}{|c|c|}
\hline $\begin{array}{l}\text { Oaion } \\
\text { Denpdration }\end{array}$ & Aqueculure \\
\hline Negligible factor & $\begin{array}{l}\text { Mejor factor in use of } \\
\text { eneroy. }\end{array}$ \\
\hline Negligible fector & $\begin{array}{l}\text { Requires sbout ane well } \\
\text { per ecre of pond in cold } \\
\text { wegther. }\end{array}$ \\
\hline
\end{tabular}

Dehydrator reduces waight by a factor of 6 - 7 and saves shipping costs.

Would not alter product quality. Could influence new industry in area.

$800-1000$ acres of onion land plus dahydrator plant would require several hundred persons.

\section{Flat terrain preferred Flat or gently-sloping terrain preferred.}

Some odor from dry. Reinjection of geotherma ing operations. Locate water. Fresh water overaway and down wind flow is clean enough to of inhabited area. support fish.

Not required

Testing to determine if equatic animals can be grown directly in particular samples of goothermal water.
Quality of Geothermal Field

\section{Multi-use}

Quality of Product

Temparature Enhancements (process require-

ment)

Peaking Tempera- Extended periods of extreme ture (woather re quirement)

Unin torruptable Supply
Can be located downstream of kiln drying.

Not affected by geothermal energy.

Not a factor cold could require peaking.

Loss of heat source could result in catastrophic crop loss.

All systems involve closed pipes. Only potential problem is corrosion and scaling.
and Modoc Counties will prevent corrosion. Low solids will minimize scaling.

Dischargas high temperature water sui table for further we by greenhouse feed lot or aqua culture but ecanomic odvantage is small.

Nor.affected by gothermal energy.

Required for some species of wood.

Not a factor

Temporary delay in production.
Can be located downstream Marginal

of kiln drying.

Carte gain more weight in heated feed lot when outdoor temperatures are low.

Not a tactor

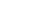

\section{Loss in production} officiency.
Not affectad by 990thermal heat.

\section{Weter must be heated from $212^{\circ} \mathrm{F}$ (study limit) to $240^{\circ} \mathrm{F}$ for 1 st stage drying.}

Not a factor

Temporary delay in production.
Current profits too low to pey for required heat exchange, but long-term potential excellent.

Heating allows maintenance of ideal temperature - higher vields.

Not a factor

Extended periods of extreme cold could require peaking.

Loss of heat source could result in catestro. phic crop loss. 


\section{B. TECHNICAL AMALYSES}

1. Greenhouses--Productivity

Recent experiments in agricultural techniques in growing of crops in greenhouses may portend immense advances in more efficient food production. The use of controlled environment (carbon dioxide, humidity and logt) and other high density grôwing techniques provide yieids which, in the words of one expert, 10 "will becomé a major factor in alleviating world food shortages and at the same time improve our economy and environment.". As proof he cites the production advantages of greenhouse grown crops over field crops as illustrated in Table V-2. Another sourcel1 claims. selling prices (in England) are 10 to 100 times the price of field crops. Even small changes in environmental control can greatly affect production. A change in temperature of only $1{ }^{\circ} \mathrm{Cll}$ could alter the return on crops by 1000 pounds (about 17 percent) per acre. Other tests indicated that control of carbon dioxide at three times ambient concentration could increase tomato yields by 40 percent.

TABLE $Y-2$

Greenhouse Ratio to Averageanfield Production per Year:

$\begin{array}{lccc}\text { Vegetables } & \begin{array}{c}\text { Greenhouse to } \\ \text { Averagenfield }\end{array} & \begin{array}{c}\text { Greenhouse } \\ \text { Productton }\end{array} & \begin{array}{c}\text { Field } \\ \text { Production }\end{array} \\ \text { Carrots } & 6 \text { to } 1 & 80 \text { tons } & 14 \text { tons } \\ \text { Cucumbers } & 96 \text { to } 1 & 450 \text { tons } & 3.73 \text { tons } \\ \text { Lettuce, Bibb } & 30 \text { to } 1 & \begin{array}{l}17,500 \text { cartons } \\ \text { of } 2 \text { Doz. Heads }\end{array} & 583 \text { cartons }\end{array}$

Bell Peppers

Chili Peppers

Radishes

Squash

Tomatoes

Watermelon
5 to 1

5 to 1

18 to 1

3 to 1

15 to 1

4 to 1
22.5 tons

12 tons

300,000

Bunches

24 tons

196 tons

10 tons
4.5 tons

2.4 tons

16,666 Bunches

8 tons

13 tons

2.5 tons

\section{October 1976 Solar Engineering}

In addition to large increases in productivity, greenhouses have the added advantages of being adaptable to land which would otherwise be unsuitable for agriculture, and requiring an order of magnitude less of water than field crops. Use of geothermal energy for heating provides yet an additional advantage--making feasible a year-round production of a large variety of crops which could not otherwise be economically produced in the study areas. 
HEAT LOAD: DESIGN - $7.2 \times 10^{6}$ BTU/HR, ANNUAL MEAN -1.8 $\times 10^{6}$ BTU/HR. GREENHOUSE

FINTUBE HEAT

AIR $75^{\circ} \mathrm{F}$ AIR $75^{\circ} \mathrm{F}$ AIR $75^{\circ} \mathrm{F}$

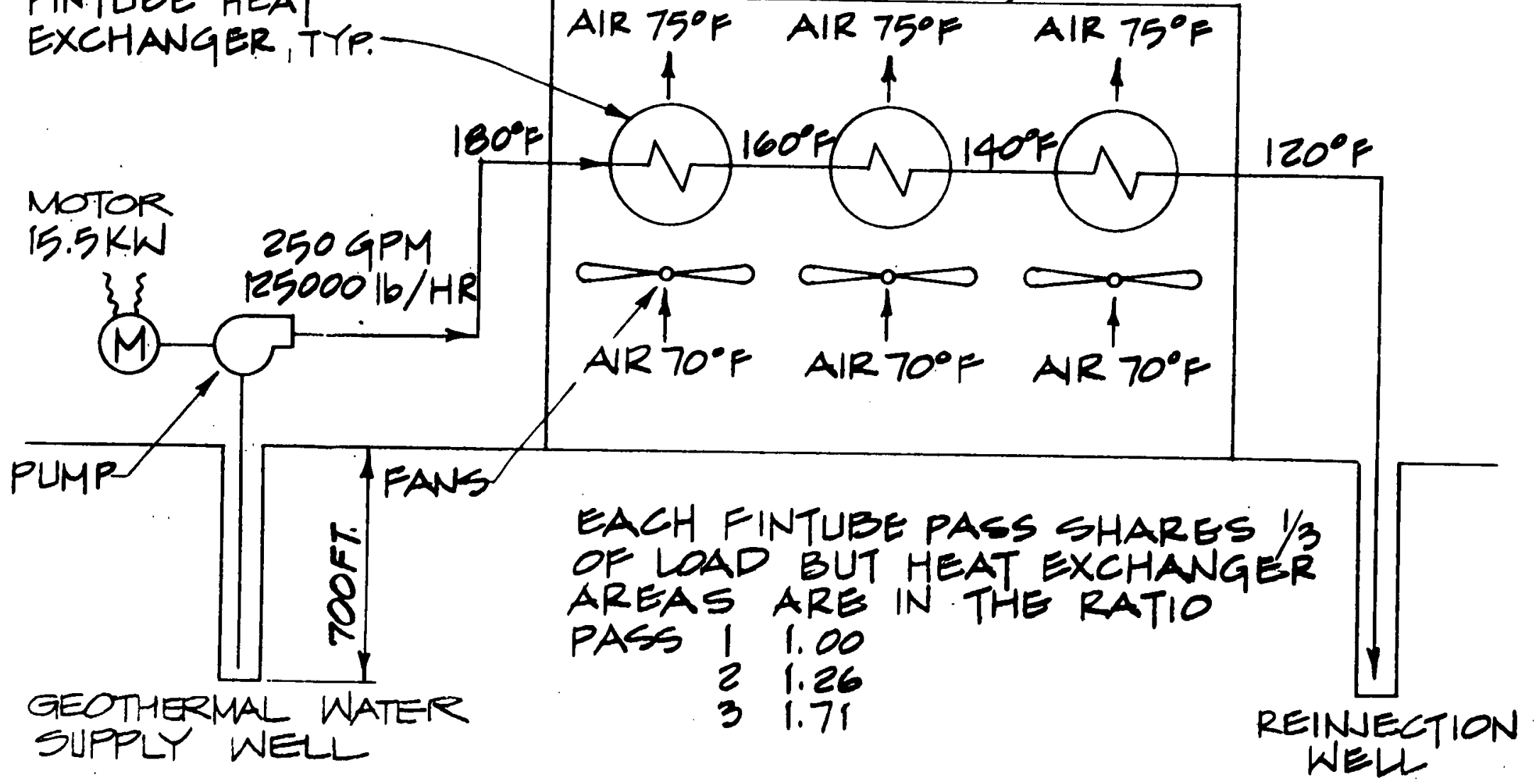

$$
\begin{gathered}
\text { I ACRE QUONSET HUT GREENHOUSE } \\
\text { DESIGN BASIS-10' } 10^{\circ} \text { OUTSIDE W/750F INSIDE } \\
\text { FIG. } \nabla-4
\end{gathered}
$$




\section{Use of Geothermal Nater in the Groenhouse}

While the parts per million of solids in the geothermal water of the study area are quite low, generally less than $1700 \mathrm{ppm}$, the:presence of some heavy metals in some samples, primarily boron, precludes the use of geothermal water in direct contact with the plants. The water quality varies greatly, and it may be possible to use it in direct contact at some locations; but for purposes of this analysis, the geothermal waters are used exclusively for heating the air in the greenhouses. (Soil warming is another potentfal use).

The water is pumped from supply wells, passed through closed finned tube heat exchange coils, and discharged to reinjection wells. Figure $V-4$ illustrates such a heating system for a one-acre quonset hut configuration.

To reduce the number of wells required, three heat exchangers are used in sericyun As the supply wells are drilled deeper, the water becomes hotter and the size and cost of heat exchangers becomes smaller. An effort was made to determine the economic optfmim for well and heat exchanger costs. Values for well depth va temperature were approxtmated from Figure V-3 using average values. But as 11 lustrated in Flgure $V_{-5}$, the lowest cost was only moderately dependent on well depth so long as it was in the range 400 to 800 feet deep.

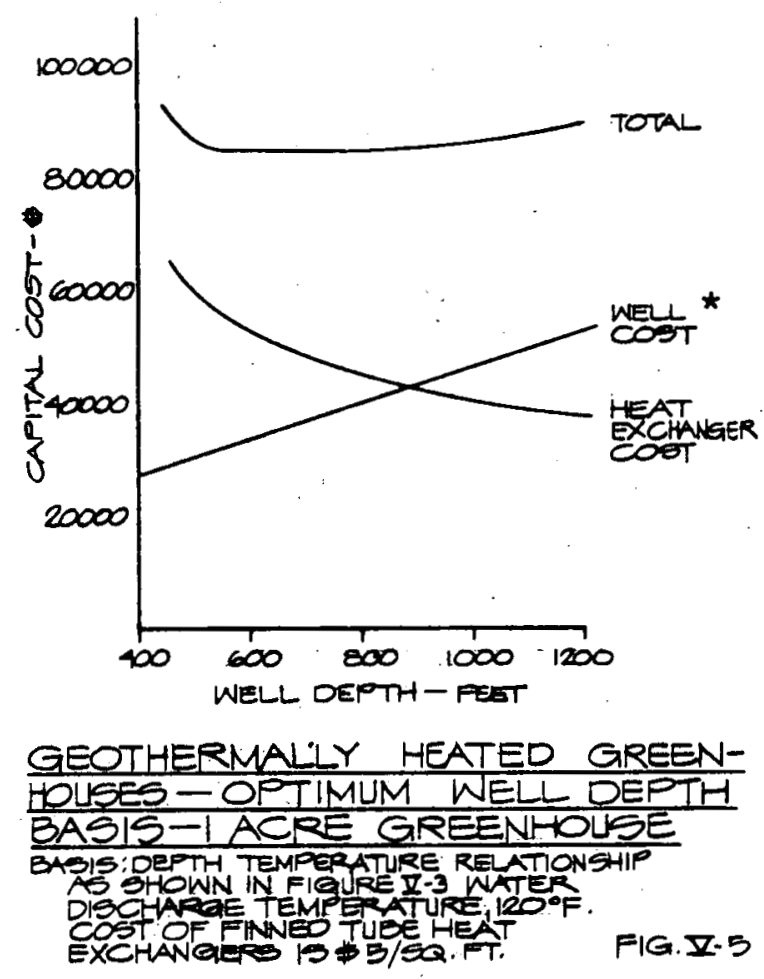

The greenhouse business clearly benefits from size or scale of operations A study conducted by Barmettler and others in 1969 showed that the per square foot investment requirement for three different size units varied substantially. The three different sizes investigated were: 10,000 square feet, 43,560 square feet and 871,000 square feet.

* Per telephone conversation with local well driller (see page 28) 


\section{GREENHOUSE INVESTMENT COSTS}

Growing Unit-Size

$$
\begin{gathered}
10,000 \text { square feet }(0.230 \text { acres }) \\
43,560 \text { square feet }(1.000 \text { acres }) \\
871,200 \text { square feet }(20.000 \text { acres })
\end{gathered}
$$

Investment Costs

$\$ 3.32 /$ square foot $\$ 2.32 /$ square foot $\$ 1.36 /$ square foot

The differences in per square foot investment for the larger 20-acre unit was $1: 2.44$ for the 20-acre unit over the 10,000 square foot house, and 1:143 for the one-acre range over the 10,0000 square foot house.

These same economics are relevant today for greenhouse operations. The 20-acre unit, although substantially more economical $(1: 1.71)$, is not so different for the five acre unit. See Figure V-6.

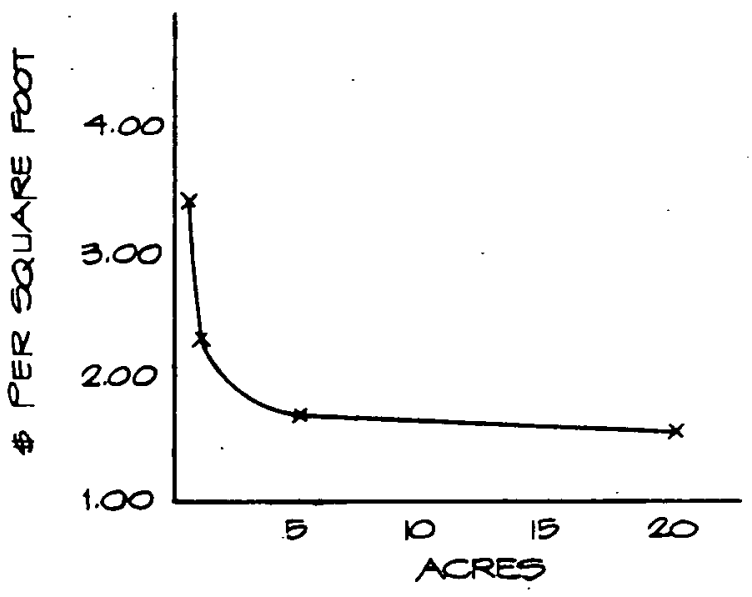

INVESTMENT ESTIMATIONS

FOR FOUR DIFFERENT GREENHOUSES
(1969-1970)
SOURCE: E. BARMETILER

SOURCE: E. BARMETILER

FIG. $\mathbf{Y}-6$ 
At 1975-76 prices, and assuming comparable costs relationships between different greenhouse sizes, the following prevails (rough estimate).

\begin{tabular}{cr} 
Growing Unit, Size & Investment \\
\hline 10,000 square feet & $\$ 6.98$ \\
43,560 square feet & $\$ 4.88$ \\
871,200 square feet & $\$ 2.86$
\end{tabular}

From the figures and the chart (Fig. V-6) it is estimated that a five-acre unit is somewhere between $\$ 4.88$ and $\$ 2.86-$ - a spread of nearly two dollars. Estimates are that a cost of around $\$ 3.25$ to $\$ 3.75$ appears practical under 1975 prices. From the above estimates, based on 1969 data, it appears that scale economics are substantial and that to be competitive a minimum five-acre greenhouse requiring a capital investment of about $\$ 210,000$ is required.

Greenhouses are particularly desirable businesses for reducing unemployment in Lassen and Modoc Counties. Labor is the single largest production cost in operation of a greenhouse. Labor intensity is fairly high, three to five laborers per acre, and should reach its peak during the winter seas on when competition from field crops is lowest. While opinions vary on the minimum economical size for a greenhouse operation, a generally accepted figure is about five to ten acres. Each 10-acre instaliation would require a minimum of 30 to 50 personnel. Ten to twelve such greenhouses in Lassen County and five in Modoc County would reduce their unemployment levels from among the highest in the nation to among the lowest. Practical considerations must account for whether the relatively small available work forces in these counties could supply the specialized kinds of labor required. Nevertheless, the potential of greenhouses to produce new job employment opportunities is apparent.

Greenhouses are normally run at $75^{\circ} \mathrm{F}$ to $85^{\circ} \mathrm{F}$ during the day. (Air temperatures are sometimes allowed to drop as low as $65^{\circ} \mathrm{F}$ at night.) Since the energy consumption is directly proportional to the difference between the ambient outdoor and the greenhouse temperatures, it is a direct function of climate. Energy consumption is high in greenhouse operations, so that using conventional fuels it would not be as practical to operate a greenhouse in Lassen and Modoc Counties during late fall, winter and early spring months. Use of geothermal energy, however, enables 12-month operation at operating costs substantially less than equivalent greenhouses in far warmer climates.

As an example, the heating costs of one-acre greenhouses located in Susanville or Cedarville using geothermal water were compared to greenhouses in Modesto, Fresno and Los Angeles using fuel oil and natural gas. Listed below are the heating degree days of each area, the annualized cost of equipment and fue 1 for the three different heating modes. Except for gas heating in Los Angeles, geothermal heating is the most economical system, with gas a close second and heating oil a distant third. It must be recognized, however, that availability of gas is rapidly diminishing, that gas costs are quickly increasing, and that geothermal energy will soon be less costly, even than gas heating in Los Angeles. 


\begin{tabular}{|c|c|c|c|c|}
\hline Location & $\begin{array}{l}\text { Heating } \\
\text { Degree } \\
\text { Days }\end{array}$ & $\begin{array}{l}\text { Annual cos } \\
\frac{\text { Capital at }}{011(3)}\end{array}$ & $\begin{array}{l}\text { ting Eqq } \\
\text { int } 10 \text { ye } \\
\frac{\text { Gas (2) }}{{ }^{2}}\end{array}$ & $\begin{array}{l}\text { ent } \$ \\
\text { plus fuel } \\
\text { Geothermal }\end{array}$ \\
\hline Susanville & 6248 & --- & & $\star 7,600$ \\
\hline Cedarville & 6255 & & & $\star 7,600$ \\
\hline Modesto & 2767 & 21,900 & 9,300 & \\
\hline Fresno & 2650 & 21,300 & 8,900 & \\
\hline Los Angeles & 1819 & 15,600 & 6,230 & \\
\hline
\end{tabular}

* Includes power cost for pumping

(2.) Gas at $\$ 1.50$ per million BTU

(3) 0 il at 38.5 cents per gallon

If all other factors are assumed equal, i.e., capital, labor, supplies, etc., a greenhouse located in Lassen or Modoc County should have a competitive advantage over an equivalent one in a warmer climate when the savings in energy costs exceed the added costs for shipping supplies and produce to market. Since the geothermally significant areas are generally remote from major markets, this balance can prove critical. These'values are compared below for greenhouses at various locations shipping tomatoes to a market in San Francisco. It will be seen that despite the much greater shipping distance, the geothermally heated greenhouse has a very large advantage over ofl heated greenhouses in Modesto and Fresno and is on a par in cost with gas heated greenhouses. By giving, added value for the uninterruptable nature of the geothermal source of energy, $4 t$ places it in a more advantageous position even than gas.

To appreciate the economic advantage of geothermal heating over oil, consider a grower in Modesto or Fresno who normally earns a profit of 10 cents per pound where greenhouse tomatoes wholesale for 50 cents per pound. The Cedarville supplier in this case would earn an additional 5 cents; an increase in profit equal to 50 percent.

A unique quality of greenhouses is that they can grow a large variety of crops, all of which require nearly the same operating temperature. The cost of heating as a consequence is nearly independent of the crop raised. Once the dollar savings in energy through use of geothermal water is known, the unit economic advantage (the energy savings in cents per pound of product) of a great variety of greenhouse products can be readily determined. This multi-product capability of the capital investment is important to financing the business. The ability to change products to follow market trends offers a unique protection and assurance of servicing of the financing. 
TRADE-OFF OF SHIPPING COSTS VS. ENERGY

COSTS FOR GREENHOUSE TOMATOES

Cedarville Presno Modesto

Miles to

San Francisco

321

186

93

Shipping Cost

$\$ / 1 \mathrm{~b}$.

1.3

(1)

0.6

(1)

0.4

Fuel Cost $\phi / 1 \mathrm{~b}$.

(2)

Geotherma 1

3.2

$0 i 1$

amm

9.5

9.5

Gas

....-

3.7

3.8

Total Cost $\phi / 1 b$,

Geotherma 1

4.5

$0 i 1$

9.5

9.5

Gas

4.3

4.2

\section{(1) Estimated}

(2) Includes capital cost of the heating system and fuel cost

(3) Basis 120 ton/acre

Marketing of greenhouse products requires good judgment in the cycling of crops and timing for delivery to the marketplace. Greenhouse products bring the largest price during off seasons of field crops. In some cases, market prices fluctuate very widely, yielding a large net loss for operations at the lower end of a fluctuation and a substantial profit at the upper end. Table V-3 lists several products which can be grown in greenhouses, their yields, costs of growing and market price ranges. On the right hand side of the Table, the savings in cost of energy achieved by growing the crop in a geothermally heated greenhouse in Cedarville, in Modoc County, over an oil heated one in Modesto is shown." The savings range from 7 to 20 percent of the wholesale prices.

Conclusions :

Application of low temperature geothermal energy to greenhouses in Modoc and Lassen Counties appears to be a most desirable application.. Greenhouses there would have a major impact. on unemployment, would have negligible deleterious environmental effects, and could compete at an advantage with greenhouses in more temperate counties. 
TABLE V-3

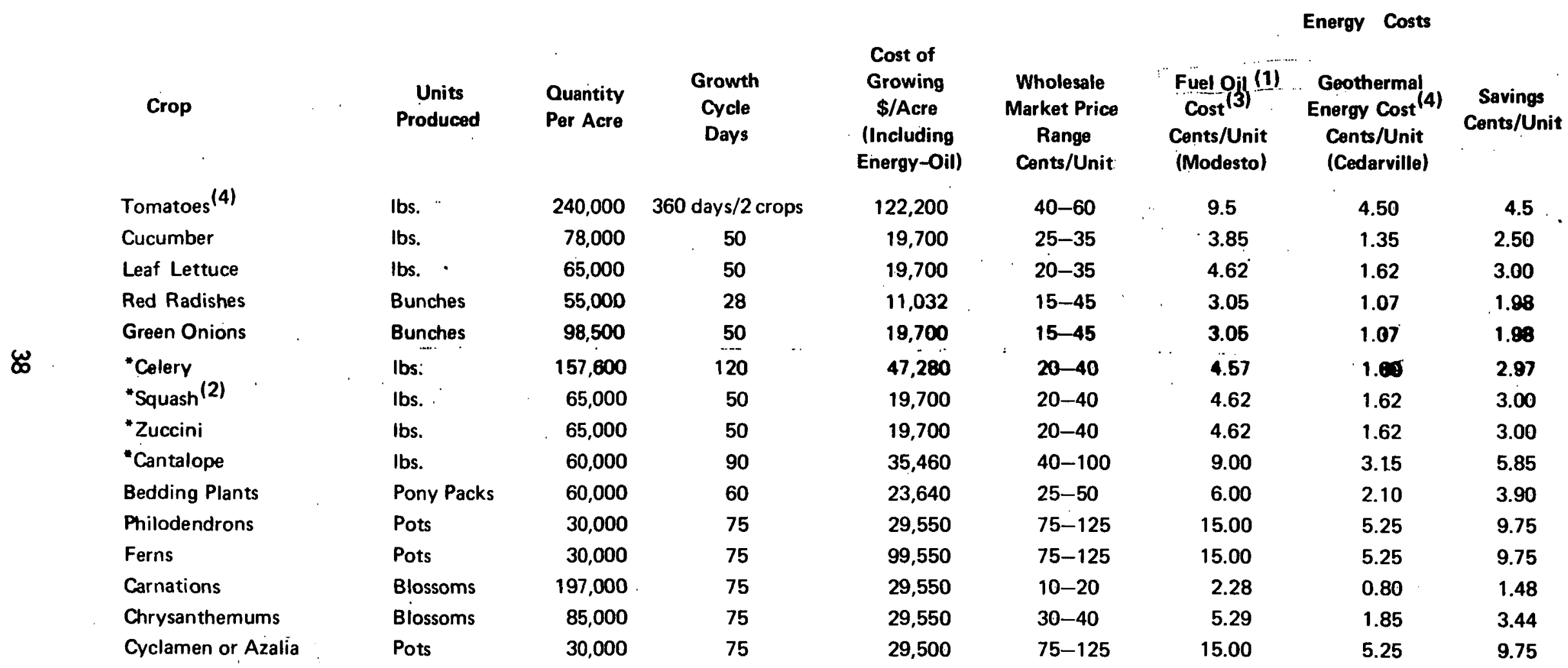

*Limited experience on greenhouse yields.

(1) Basis: Modesto, California 2767 Heating Days

(3) At $\$ 60 /$ day average over one year.

(2) Straight yellow or butterfly squash

(4) At $\$ 21 /$ day average over one year. 


\section{Kiln Drying Lumber}

Lumbering has been and continues to be the only major manufacturing activity in Lassen and Modoc Counties. Although it remains quite important in the area, improved technology coupled with increased competition by firms outside the area have reduced the number of mills and the number of associated jobs in this industry. Developing an economic edge through lower cost forms of energy becomes critical priority in this industry. Presently four sawmills operate in Lassen County: Coin Lumber and Sierra Pacific Industries in Susanville, Little Valley Lumber Co. and Main Lumber Co. in Bieber. Total annual production in 1974 was $125,646,230$ board feet. There are three sawmills in Modoc County whose capacity in 1968 was 2,000,000 board feet.

In small saw mills where drying kilns are heated by steam from conventional oil-fired boilers, substitution of geothermal energy for the heating energy source can achieve substantial energy cost savings. In larger, well integrated mills, all energy from operations can be provided by burning sawdust and other wood waste products. If a market develops for the: waste products or where the energy can be more economically applied elsewhere, the geothermal source may also become economical in integrated plants. It is evident that such a by-product market is developing. Bohemia, Inc., (Eugene, Oregon) has built a $\$ 4.25$-million plant capable of treating 400,000 tons/year of bark to provide plywood extender and vegetable wax. Secondary uses for sawdust, however, are still a problem. Drying lumber in batch kilns is standard practice for most upper grade lumber in the western United States. The two basic purposes of drying are to set the sap and to prevent warping.

The sap sets at $135^{\circ}$ to $140^{\circ} \mathrm{F}$. Warping is prevented by establishing uniform moisture content throughout the thickness. Lumber left to dry under ambient conditions loses its moisture from exposed surfaces at a faster rate than internally. This differential drying rate sets up stresses which cause the warping. Moisture occurs in wood in cell cavities and in the cell walls. The majority of the moisture is first lost from the cavities. This loss is not accompanied by changes in the size of the cell or in warpage. When water is lost from the cell walls, however, shrinkage of the wall fibers take place setting up the stresses. which cause warping.

In the kiln drying process, the evaporation rate must be carefully controlled to prevent these stresses. The allowable drying rates vary from species to species and decrease with thicker cut sizes. Kiln drying is usually carried out as a batch process. The kiln is a box shaped room with loading doors at one end. It has insulated walls and celling and has fans to recirculate the air at high velocity through the lumber. The sawed lumber is spaced and stacked to assist the free air movement and is loaded by large fork lifts or other specialized lumber handling trucks into the kiln. When fully loaded, the doors are closed and the heating cycle is started. Make up air, preheated to a temperature consistent with the drying schedule, enters the kiln where it recirculates through the stacked lumber and picks up moisture. Exhaust fans draw the moist air from the kiln and discharge it to the atmosphere. The exhaust is primarily air and water. The rates of flow and temperature are adjusted so that the temperature and the humidity in the kiln will retard the drying rate sufficiently to prevent warping. During the drying cycle, the lumber loses a large portion of its weight from evaporation of water, 50 to 60 percent for many species. 
Drying schedules are specific for each species of lumber and for size. The larger the size and the more tightly the motsture is held in the wood fiber, the slower the schedule. Drying schedules range from less than 24 hours to several weeks per batch. Table $V-4$ shows typical drying schedules for ponderosa pine. It will be noted that drying proceeds slowly as evidenced by the gradual decline in the EMC, equilibrium moisture content of the wood.

In heavier lumber cuts it is sometimes necessary to remoisturize the surface at the end of the schedule (see select 12/4 ponderosa pine in Table V-4). Remoisturizing is achieved by raising the wet bulb temperature, and is done to reduce the stress differences caused by law surface moisture compared to higher moisture in the heart of the lumber.

\section{TABLE $V=4$}

TYPICAL KILN DRYING SCHEDULES

Ponderosa pine

4/4 A11 Heart Common Sort (fast on well sorted stock)

\begin{tabular}{|c|c|}
\hline Dry Bulb $\left({ }^{\circ} \mathrm{F}\right)$ & Wet \\
\hline $\begin{array}{l}160^{\circ} \\
\text { No conditioning }\end{array}$ & 30 \\
\hline $\begin{array}{l}150^{\circ} \\
150^{\circ} \\
160^{\circ}\end{array}$ & \\
\hline
\end{tabular}

No conditioning

4/4 Half and Half Common (Mostly 8")

Shop and Select 12/4 $160^{\circ}$

No conditioning

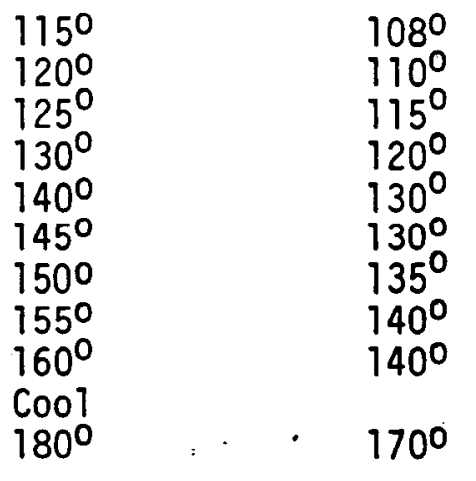

$140^{\circ}$
E.M.C. $(\%)$

Approx. $21 \mathrm{hrs} . \quad 5.8$

up to setting to $12 \mathrm{hrs}$.

12 hrs.till dry (24-28 hrs.)

40-50 hrs.

8.0

6.9

5.8

First day

Second Day

Third Day

Fourth Day

5th-10th

10th-12th

12th-16th

15th-18th

18th-22nd

14.1

12.1

12.1

12.1

11.9

9.5

9.5

9.4

7.9

Approx.24 hrs. 11.1 Equalizing \& Conditioning

\section{E.M.C. = Equilibrium Moisture Content}

From Kiln-drying Western Softwoods, Moore Dry Kiln Company, Oregon. 
Green wood contains high quantities of moisture. Ponderosa pine, for example, runs approximately 60 percent moisture. Because of the physical and chemical binding to the wood chemicals it takes from one and one half to three times the energy to evaporate moisture from wood as it does from pure water. Energy consumed in kiln drying wood varies considerably for different species. Drying energy therefore, varies widely with the species and sizes processed.

ENERGY CONSUMED IN KILN DRYING WOOD

\begin{tabular}{llc} 
Lumber & $\begin{array}{l}\text { Energy Use } \\
\mathrm{BTU} / 1 \mathrm{~b} \mathrm{H} \mathrm{H}_{2}\end{array}$ & $\begin{array}{c}\text { BTU/Dry } \\
\text { Board Feet }\end{array}$ \\
\cline { 2 - 2 } $\begin{array}{l}\text { Douglas Fir } \\
\text { Southern Yellow Pine }\end{array}$ & $2000-3000$ & $1560-2340$ \\
Red Oak & $1600-2200$ & $4600-6300$ \\
& $3000+$ & $7850+$.
\end{tabular}

Other kiln schedules call for high temperature drying at temperatures to $240^{\circ} \mathrm{F}$

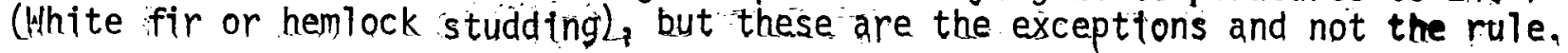

The species which predominate in the study area include White fir, Ponderosa pine, Jeffrey pine, Lodgepole pine, Incense-cedar and Quaking aspen.

Geothermal energy would be adapted to kiln drying by passing air over finned heat exchanger tubes carrying the hot water. The finned tube heat exchanger could be placed inside existing kilns so that the air recirculation route would include a pass over the heat exchangers. For economic design, the water temperature must be at least 20 to $40^{\circ} \mathrm{F}$ above the ambient operating temperature in the kiln. This would mean digging the supply wells deeper than for most other low temperature applications of geothermal energy to obtain temperatures in the range 200 to $240^{\circ} \mathrm{F}$. Where geothermal water of insufficient temperature is available (less than $180^{\circ} \mathrm{F}$ for most uses), energy supplies could be supplemented by conventional heating systems during the final high temperature portions of the drying schedules.

Geothermal heating in kilns is thermodynamically very inefficient. The only part of the water heat available for drying in the $k i l n$ is its sensible heat between its entry temperature and a temperature 10 to $20^{\circ} \mathrm{F}$ above the ambient kiln temperature. Thus if $200^{\circ} \mathrm{F}$ water was used to heat a kiln whose schedule called for $140^{\circ} \mathrm{F}$ at the start of the drying schedule and $180^{\circ} \mathrm{F}$ at the end, only 10 to 15 percent of the heat in the water would be available for drying. Minimum geothermal water temperatures for several sizes and species of lumber are shown below. 


\section{MINIMUM GEOTHERMAL WATER TEMPERATURES}

FOR KILN DRYING

Species

Ponderosa Pine

Sugar Pine

Englemen Spruce

Sitka Spruce

Douglas Fir

Incense Cedar
Minimum Geothermal Water

Temperature $0^{\circ} \mathrm{F}$ a $\mathrm{k} t \mathrm{ln}$ in let

Lumber Size

$\begin{array}{cc}\frac{4 / 4}{175} & \frac{8 / 4}{195} \\ 175 & 175\end{array}$

175

$195 \quad 195$

$195 \quad 195$

185

The discharged water for these applications would have temperatures ranging from 160 to $180^{\circ} \mathrm{F}$ and would be avallable for other applications in the mill, for heating of office buildings, or for outside multi-use low temperature applications such as cattle feed lots and fish farming.

Adaptation of geothermal energy to kiln drying would not directly affect employment because the drying facilities already exist, and it is unlikely that its economic advantages would justify the construction of entire new saw mills. The lumber industry in Modoc and Lassen Counties, however, has been decreasing over the last several decades. The increased efficiency contribution by geothermal energy should help saw mills in these counties compete with outside mills and slow or reverse the employment trend.

To illustrate the comparative advantages of geothermal energy for kiln drying, a theoretical analysis was prepared based on use of $200^{\circ} \mathrm{F}$ water from a well with a capacity of $260 \mathrm{gpm}$ for drying in a kiln with a capacity of 100,000 board feet per batch. The kijn drys $4 / 4$ Ponderosa pine Sap common to a final dry bulb temperature of 150 over a 66 -hour drying schedule.

The drying schedule is as follows:

Dry Bulb
Temperature
$\circ \mathrm{F}$

140

150
Wet Buib

Temperature ${ }^{\circ} \mathrm{F}$

115

120
Time

Hours

$0-24$

24-66

(1.42 pounds of water evaporated per board foot)

The analysis compared the annual operating cost of a geothermal system to a conventional one, using an oil fired boiler. The flow diagrams are outlined in Figure $V-7$ showing the basic quantities of air and fuel flow based on heat 


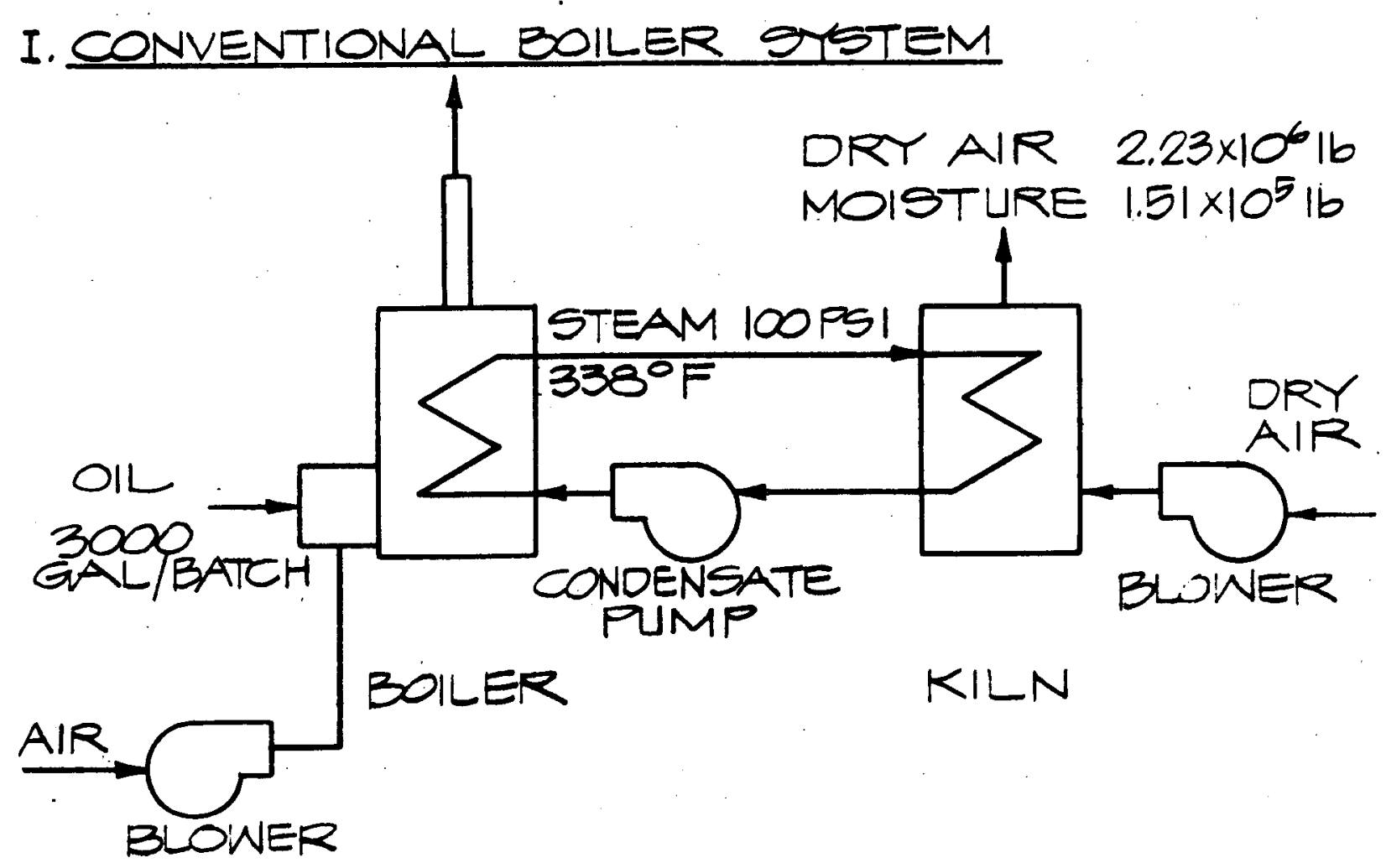

II. GEOTHERMALLY HEATED SYSTEM MOISTURE $1.51 \times 10^{5} 16$

TO DISPOSAL

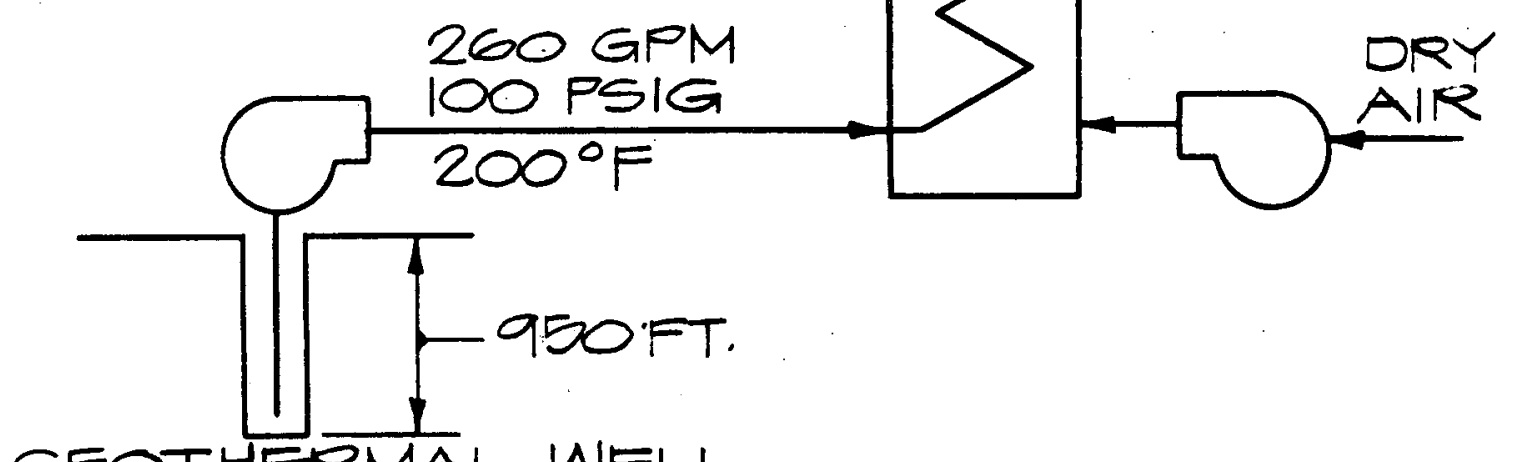

GEOTHERMAL WELL

$\frac{K I L N \text { DRYING LUMBEK }}{60 \text { HR, SCHEOILE }}$

(PONDEROSA-4/4 SAP COMMON)

$F \mid G \cdot \nabla-7$ 
and material balances. Despite its low thermal efficiency, the geothermal system had a low annual operating cost of $\$ 15,000$. This figure was based on modification of an existing kiln and included pump operating costs and capital depreciation costs of the geothermal supply and disposal system and process heating equipment based on nine percent interest rates and a ten-year life. The conventional boiler system was assumed to be in existence, so that only fuel costs were charged against it. These amounted to $\$ 126,000$ per year, a savings of $\$ 111,000$ per year ( 1.06 cents per board foot).

The outlook for the lumber industry in Modoc and Lassen Counties is encouraging in a limited sense. It is probable that the worst of the decline is over. As the industry recovers and gains enough working capital for modernization, more by-product use of lumber waste products will develop and the application of geothermal energy for kiln drying will become more attractive. Conversion of wood wastes, particularly sawdust, from use as a fuel to use as a by-product can lead to new employment opportunities. A significant portion of these opportunities would occur in the important blue collar sector of the labor force. 


\section{Food Processing--Onton Dehydration}

Low temperature drying in the food processing industry is especially adaptable to geothermal energy as the heat source. This is because drying requires large quantities of low intensity heat. The geothermal energy source is one of the least expensive, and its temperature is less likely to get out of control and overheat the product. Onion drying fits into this category particularly well because the onions are dried to only 0.18 of their original welght. For each pound of product, 5.4 pounds of water must be evaporated and in excess of 10,0000 BTU of heat provided.

Onions are grown in the Tule Lake area along with potatoes. Surprise Valley also grew onions but, though the quality of the crop was good, poor market conditions discouraged further development there before the crop could become established. Onion drying is an intensive process. One dryer installation of the type described below would process the output of 800 to 1000 acres. Bringing such large agricultural areas into production, coupled with the storage, transportation and processing of the onions, would affect the employment of several hundred people.

Onions grown for processing are of very specific varieties suited for dehydration. The dehydration industry has developed the Creole Onion, the Southport Globe Onion, and the hybrid Southport Globe. These onions are white in color and are more pungent and substantially higher in solids than the commercial household product purchased in local grocery establishments. The crop is harvested mechanically, and transported to the dehydrator in bulk.

The normal handling procedures for onions are as follows: the bulk onions are taken to the dehydrators and are loaded into large bins for curing; dry air is passed through the onions to take off the excess surface moisture. This treatment prepares the onion for further processing. The curing treatment may continue up to 72 hours.

From the curing bins, the onions are moved by conveyors or other mechanical means to the processing line. Here the product is inspected (inspections start in the field), and any tops are removed; the onion is washed under a high pressure washer, then soaked in stainless steel tanks, washed again under pressure and resoaked in a chlorine bath to reduce bacteria levels. The onions are then placed into stainless steel storage tanks. The onions are fed into a slicer from the storage tanks, and are then moved along the line to the dryer.

The dryer used is a machine developed by Proctor and Schwartz for a California vegetable processing firm. The dehydrator is a 200-foot four-stage system. The system is highly automated, capable of handling 10,000 pounds of raw product per hour, or 240,000 pounds per 24-hour period. From the slicer, a continuous flow carries the onion slices to the dryer, at which point the wiper spreads the onion slices evenly over the open feed end extension of the dryer. At this point the product is transferred to the continuous dryer conveyor for the first stage of the four-stage dryer. 


\section{The Onion Drying Process}

\section{Stage I:}

The Proctor and Schwartz onion dehydrator is composed of a four-stage perforated belt conveyor system. The first stage is where the bulk of the molsture in the product is removed. It is a critically important stage, since product quality is determined by control over the moisture removing process. Temperature and air volume are closely measured; in this first stage the air temperature is maintained at $210^{\circ} \mathrm{F}$. The Proctor and Schwartz model is capable of exhausting 31,500 cubic feet of moisture laden air per minute in this first stage of operations.

\section{Stage II:}

At this point, where the bulk of the readily removable moisture has been exhausted, the onions are transferred to the second processing stage (dehydrator). At the point of separation, devices are used to load the second stage to greater depth of onions on the conveyor. The partially dried onion slices are separated so that air can move freely through the product in this second stage of dehydration. The temperature is lowered to $180^{\circ} \mathrm{F}$, and the atr volume is also reduced by about 35 percent. As the product moves through this operation, the onions are turned and mixed so that the deeply diffused water is slowly withdrawn from the onion slices.

\section{Stage III:}

Stage three continues to extract the more deeply diffused water. The product moves from the second stage to the third stage, and again the temperature is lowered as is the air volume. The more deeply loaded conveyor moves through a drying temperature of about $150^{\circ} \mathrm{F}$, and the volume of air flow is lowered another 25 percent. In this third stage, very deeply diffused and difficult to extract water is further removed. Since very little moisture remains in the product, quality maintenance needs to be guarded very closely; up to this point, moisture evaporations moderated the effect of heat on the product slices.

\section{Stage IV:}

The final stage receives the onions; they are waded to a six foot depth. Dehumidified air is moved through the six-foot layer to bring the product to its final milling quality. In Stage IV, temperatures are reduced to about $135^{\circ} \mathrm{F}$, but the air volume is again increased by 25 percent. 
$10,000 \mathrm{lbs} / \mathrm{hr}$. CAPACITY-RAW PRODUCT (Single Line)

Processing

Stage
Air Volume

Cubic Ft./min.
Atr

Temperatures

\begin{tabular}{|c|c|c|}
\hline I & 31,500 & $210^{\circ}$ \\
\hline II & 20,000 & $180^{\circ}$ \\
\hline III & 15,000 & $150^{\circ}$ \\
\hline IV & 20,000 & $135^{\circ}$ \\
\hline Single Line Totals: & $\begin{array}{l}86,500 \text { cubic } \\
\text { Ft./min. }\end{array}$ & $\begin{array}{l}290,000 \\
\mathrm{BTU} / \mathrm{min}\end{array}$ \\
\hline $\begin{array}{l}\text { Probable Investment Required } \\
\text { (Gallon heated system) } \\
\text { Land Resources ( } 8 \text { acres) } \\
\text { Proctor \& Schwartz Dryer } \\
\text { Building } 300^{\circ} \times 50^{\circ} \times \$ 15\end{array}$ & $\begin{array}{l}\text { (Twin-Line) } \\
\text { \& Service Equip. }\end{array}$ & $\begin{array}{r}156,000 \\
\$ 2,850,000 \\
350,000 \\
\$ 3,356,000\end{array}$ \\
\hline
\end{tabular}

The air is induced and pushed by fans with over 40 million BTUs per hour heat source capacity; it is estimated that to produce about 70,000 pounds of dehydrated onions per day, it will require between $35,000,000$ to $50,000,000$ BTU per hour, depending on a wide variety of both internal and external environmental and product variables ( 350 to 500 therms per hour).

Assuming a 24-hour run and a five-month operation, the energy demand would be very substantial. (Where storage capacity is sufficient the operating season could be extended).

$42,500,000 \mathrm{BTU} / \mathrm{hr} \times 24 \mathrm{hr} /$ day $=$

10,200 therms $/$ day $\times 150$ days $/$ season $=1,530,000$ therms.

Priced at $29 \$$ per therm $=\$ 443,700$ for fuel oil

The operations plan assumes a fuel cost of $\$ 440,000$ to $\$ 450,000$ for a twin line dryer plant. The plant is calculated to cost (Capital Investment) roughly 3.25 to 4.00 million dollars. The recent changes in metal prices and labor costs have driven the cost of engineering substantially higher than just three years earlier when the same investment could have been achieved for roughly 2.2. million dollars.

It is estimated, aga in from the above, that a well engineered arrangement as visualized above could produce about 70,000 pounds of dried onions per day or about $10,500,000$ pounds during the five-month drying season. To produce $10,500,000$ pounds of dry product, it will require roughly $35,000,000$ pounds of fresh product per line, or $70,000,000$ pounds. Assuming about 40,000 pounds of usable onions per acre, it would require the production of 800 to 1,000 acres of good onion producing land. 
Per Season Estimates

Inputs

$70,000,000$ lbs.
Output

$10,500,000$ lbs.

Per Day Estimates

460,000 lbs.

$$
69,000 \text { lbs. }
$$

Per Hour Estimates

19,200 lbs.

\section{Acres}

875

\section{ENERGY DEMAND - TWINLINE ONION DEHYDRATORS CAPACITY 230,000 1b. Raw Product Per $24 \mathrm{Hr}$. Day}

BTU Required

(Period)

Per Hr.

Per 24 Hrs.

Per 150 Day Season

Per Ton of Product

Per Pound of Product
BTU

$42,500,000$

$1,020,000,000$

$153,000,000,000$

$29,142,860$

14,575
Bbls. of 0 i1

0.48

One $\mathrm{Bbl}$ refined heating oil $=58.8$ Therms ( 42 U.S. Gallons).

One U.S. Gallon $=140,000$ BTU $=1.4$ Therm.

Per $\mathrm{hr}$. production of finished onion product 1,438 pounds or 0.72 tons per line.

1.4 Therm $=40 \notin=1$ U.S. Gallon No. 2 fuel oil

1.0 Therm $=28.57 \$=.714$ U.S. Gallons No. 2 fuel $0 i 1$

The fuel cost for producing $11 \mathrm{~b}$. of finished product is calculated to be $4.164 ф$. 
An application of geothermal energy to such a process is outlined in the flow diagram shown in Figure V-8. Use of geothermal energy would not affect the quality of the product since ft would not change the control temperatures. The onions are fed in on the left stde and plow through the successive stages to the right. Air flows countercurrent to the onton flow, tncreasing its temperature between stages by passing over geothermally heated cotls in the heat exchanger.

To meet the total requirements, deep wells are requtred because of the need for $240^{\circ} \mathrm{F}$ water. If such high termperature water is not avatlable, then the geothermal energy source would heat only the latter three stages, and a conventional heater could be used to heat the first (this heat could be provided by boosting the temperature of the al ready hot geothermal water with hydrocarbon fuels). The first stage requires intensive high temperature heat; the quantfty of heat required is much greater than the other stages, so that it would greatly reduce the fuel savings.

It is estimated that the cost of the geothermal supply and reinjection wells, the auxiliary equipment and the four stages of heat exchange in the drying process would cost $\$ 202,000$ annually (based on nìne percent interest and 10-year depreciation). Since the energy cost based on use of fuel ofl was $\$ 437,000$ for a 150 -day season, this represents potential annual savings of $\$ 235,000$, equal to 2.24 cents per pound of dry product compared to the wholesale price of sliced dehydrated ontons (1/77) of approxtmately $\$ .98$ to $\$ 1.25 /$ pound. A check with the manufacturer of the drying equTpment, Proctor \& Schwartz, indfcated that a savings of this magnitude would be of interest. 


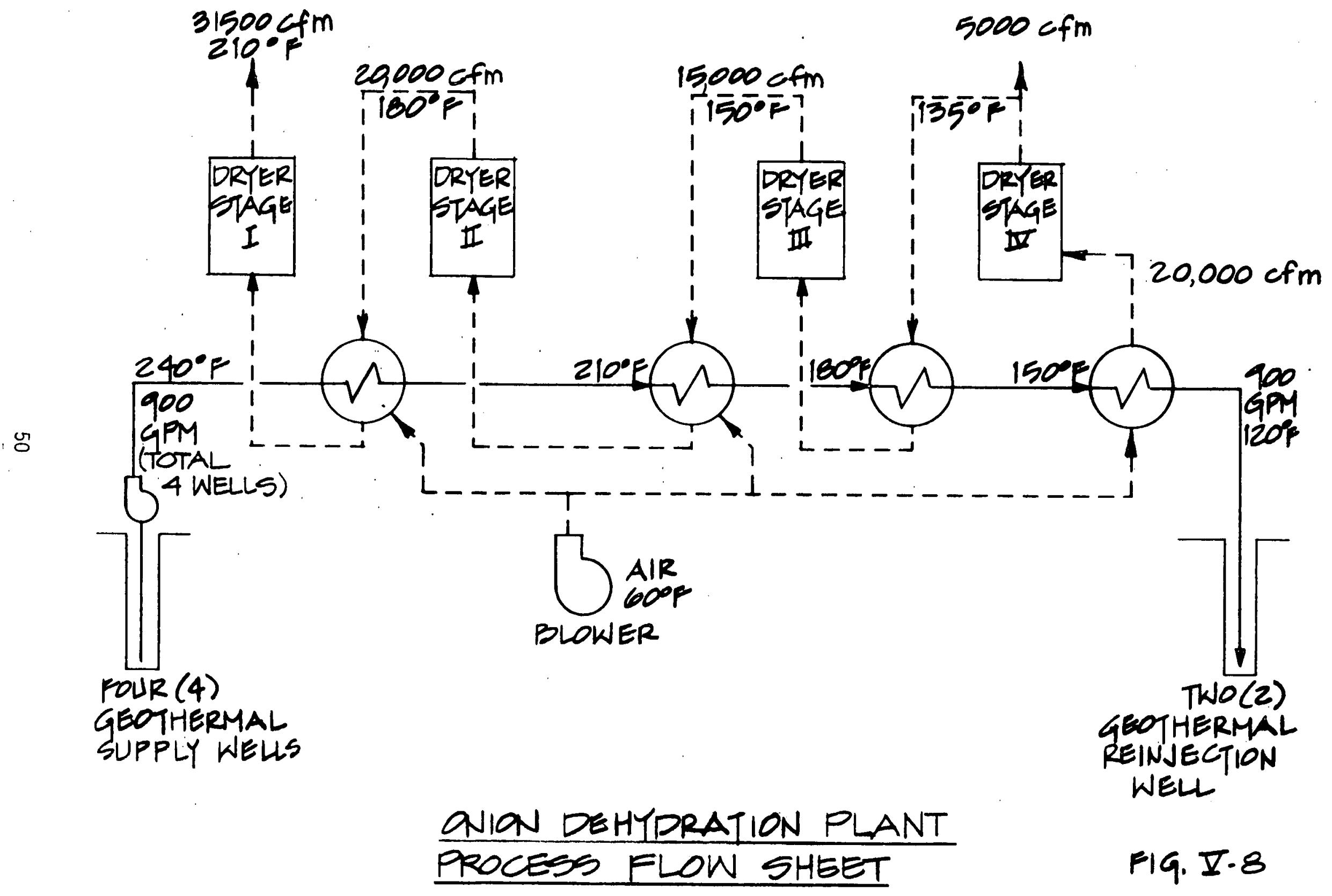




\section{Feedlot Heating}

Winter feeding cattle in geothermally heated areas offers the following advantages:

- It would enable the marketing of more valuable beef, finished yearling steers (1050 lbs) at 7 to 10 cents more per pound, than backgrounding calves (670 lbs).

- The conversion of food weight to animal weight would be greater.

- It woutd reduce mortality.

This study analyzed the advantages and disadvantages for two feedlots, one in which a small feedlot is operated by an individual rancher, and a second designed to handle cattle from large surrounding areas.

Heal thy ruminant animals such as beef cattle are walking heat sources, because the fermentation of food products generates large quantities of heat. Nevertheless, extreme cold can have a negative impact on the animals' health and weight gain. This factor, coupled with a shortage of feeds, causes ranchers in the vicinity of Susanville to ship animals south during the winter months. In the Surprise Valley area where feed is more plentiful, some herds are held over the winter months despite the cold weather.

Low temperature appears to have two important effects on the animals' weight gain. First, a temperature exists below which an animal must elevate its heat production in order to maintain body temperature. This temperature varies with animal size, coat condition and acclimatization. The elevation in heat production of necessity means that food is diverted from productive processes to that of heat generation to replace that lost to the environment. Young 13 defined the environmental temperature as the "critical temperature." He calculated the stress on an animal by multiplying the temperature below critical by the number of days over which the temperature occurred, i.e., degree-days, and showed the quantity of energy and feed required for the animal to maintain weight as shown in Table V-5.

TABLE V-5

ESTIMATED EXTAA RATION EMEAOY REOUMED TO COMMEMSATE FOR EACH UMIT OF COLD STRESS. COLD STRESS IS MEASURED IN UNITS OF DEGREE-F DAYS OR DEGREE-C DAYS AND REPRESENTS THE NUMBER OF DEGREES THE DAILY EQUIVALENT STILL AIR TEMPERATURE OF THE ENVIRONMENT IS BELOW THE CRITICAL TEMPERATURE OF THE ANIMAL

\begin{tabular}{|c|c|c|c|c|c|c|}
\hline \multirow{3}{*}{$\begin{array}{c}\text { Thermal } \\
\text { insulation } \\
\text { of the } \\
\text { animal } \\
\text { Mcal. } \mathrm{m}^{-2} .24 \mathrm{~h}^{-1}\end{array}$} & \multicolumn{6}{|c|}{ Extra ration required to compensate for cold stress (energy/degree day) } \\
\hline & \multicolumn{3}{|c|}{ For one degree-F day. } & \multicolumn{3}{|c|}{ For one degree-C day. } \\
\hline & $\begin{array}{c}\text { Metab. } \\
\text { energy } \\
\text { Mcal. }\end{array}$ & $\begin{array}{c}\text { Grass* } \\
\text { hay } \\
\text { lb. }\end{array}$ & $\begin{array}{c}\text { Barley* } \\
\text { grain } \\
\text { lb. }\end{array}$ & $\begin{array}{c}\text { Metab. } \\
\text { energy } \\
\text { Mcal. }\end{array}$ & $\begin{array}{c}\text { Grass* } \\
\text { hay } \\
\text { lb. }\end{array}$ & $\begin{array}{c}\text { Barley* } \\
\text { grain } \\
\text { lb. }\end{array}$ \\
\hline 5 & 0.111 & 0.148 & 0.092 & 0,200 & 0.266 & 0.166 \\
\hline 10 & 0.056 & 0.074 & 0.046 & 0.100 & 0.133 & 0.083 \\
\hline 15 & 0.037 & 0.049 & 0.031 & 0.067 & 0.089 & 0.056 \\
\hline 20 & 0.028 & 0.037 & 0.023 & 0.050 & 0.067 & 0.042 \\
\hline 25 & 0.022 & 0.029 & 0.018 & 0.040 & 0.053 & 0.033 \\
\hline 30 & 0.018 & 0.024 & 0.015 & 0.033 & 0.044 & 0.027 \\
\hline 35 & 0.016 & 0.022 & 0.013 & 0.029 & 0.039 & 0.024 \\
\hline 40 & 0.014 & 0.018 & 0.012 & 0.025 & 0.033 & 0.021 \\
\hline 45 & 0.012 & 0.016 & 0.010 & 0.022 & 0.029 & 0.018 \\
\hline 50 & 0.011 & 0.015 & 0.009 & 0.020 & 0.027 & 0.017 \\
\hline
\end{tabular}

*Grass hay with 0.75 Mcal. metabolizable energy/lb. and barley grain with 1.21 Mcal. metabolizable energy/lb. 
A second effect of low temperature is to reduce the abjlity of the animal to efficiently digest its feed. Young and Christooherson 14 measured the prolonged cold effects on digestion and metabolism in irumiriants and showed decreased digestibilittes relattve to $18^{\circ} \mathrm{C}$ (value $=1 \mathrm{C}, \mathrm{U}$ ) as shown in Table V-6.

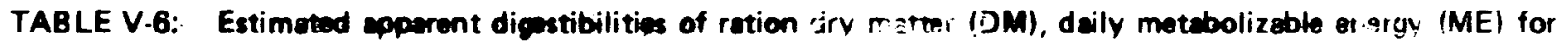
maintenance and goin, and cotal fad requiroments of a ciry prrignent boof cow and a fooder steer with access to shelter but no supplementary heating in Edmonton, Can'ids.

\begin{tabular}{|c|c|c|c|c|c|c|c|}
\hline Month & $\begin{array}{l}\text { Mean } \\
\text { tomp. } \\
(C)\end{array}$ & $\begin{array}{l}\text { DM } \\
\text { dig. } \\
(\%)\end{array}$ & $\begin{array}{l}\text { ME for } \\
\text { maint. } \\
\text { (Mcal) }\end{array}$ & $\begin{array}{l}\text { ME for } \\
\text { gain } \\
\text { (Mcal) }\end{array}$ & $\begin{array}{l}\text { Added ME for } \\
\text { direct cold } \\
\text { (Mcal) }\end{array}$ & $\begin{array}{l}\text { Total } \\
\text { feed } \\
(\mathrm{kg} \mid\end{array}$ & $\begin{array}{c}\text { Raquirement } \\
\text { ic a ive to } \\
\text { is C }\end{array}$ \\
\hline \multicolumn{8}{|c|}{ DRY PREGNANT COW, $500 \mathrm{~kg}$; ration in warm (18C) 55\% DM dig. and $2.0 \mathrm{Mcal} \mathrm{ME} / \mathrm{kg}$. } \\
\hline $\begin{array}{l}\text { Jan } \\
\text { Feb }\end{array}$ & $\begin{array}{l}-15.0 \\
-10.5\end{array}$ & $\begin{array}{l}47.1 \\
48.2\end{array}$ & $\begin{array}{l}15.7 \\
15.4\end{array}$ & - & $\begin{array}{l}0.6 \\
0.3\end{array}$ & $\begin{array}{l}9.52 \\
8.99\end{array}$ & $\begin{array}{l}140 \\
132\end{array}$ \\
\hline Mar & 5.6 & 49.3 & 15.1 & - & 0.2 & 8.56 & 126 \\
\hline Apr & 4.0 & 51.6 & 14.5 & - & 0 & 7.71 & 113 \\
\hline May & 11.0 & 53.3 & 14.0 & - & 0 & 7.24 & 106 \\
\hline Jun & 14.5 & 54.2 & 13.8 & - & 0 & 7.02 & 103 \\
\hline Jul & 17.5 & 54.9 & 13.6 & - & 0 & 6.82 & 100 \\
\hline Aug & 16.0 & 54.5 & 13.7 & - & 0 & 6.93 & 102 \\
\hline Sep & 11.0 & 53.3 & 14.0 & - & 0 & 7.24 & 106 \\
\hline Oct & 5.5 & 52.0 & 14.4 & - & $n$ & 7.61 & 112 \\
\hline Nov & $\cdot 4.0$ & 49.7 & 15.0 & - & 5.2 & 8.38 & 123 \\
\hline Dec & -10.8 & 48.1 & 15.4 & - & 0.4 & 9.06 & 133 \\
\hline Average & 2.8 & 51.4 & 14.6 & - & 0.14 & 7.92 & 116 \\
\hline \multicolumn{8}{|c|}{ FEEDER STEER, $400 \mathrm{~kg}$ and daily gain $1 \mathrm{~kg}$; ration in warm (18C) $70 \% \mathrm{DM}$ dir, and $2.5 \mathrm{Mcal} \mathrm{ME} / \mathrm{kg}$. } \\
\hline Jan & -15.0 & 62.1 & 12.3 & 12.6 & 0 & 11.20 & 121 \\
\hline Feb & -10.5 & 63.2 & 12.0 & 12.6 & 0 & 10.90 & 118 \\
\hline Mar & -5.6 & 64.3 & 11.8 & 12.6 & 0 & 10.60 & 115 \\
\hline Apr & 4.0 & 66.6 & 11.3 & 12.6 & 0 & 10.02 & 108 \\
\hline May & 11.0 & 68.3 & 10.9 & 12.6 & 0 & 9.62 & 104 \\
\hline Jun & 14.5 & 69.2 & 10.7 & 12.6 & 0 & 9.43 & . 102 \\
\hline Jul & 17.5 & 69.9 & 10.5 & 12.6 & 0 & 9.25 & 100 \\
\hline Aug & 16.0 & 69.5 & 10.6 & 12.6 & 0 & 9.36 & 101 \\
\hline Sep & 11.0 & 68.3 & 10.9 & 12.6 & 0 & 9.62 & 104 \\
\hline Oct & 5.5 & 67.0 & 11.2 & 12.6 & 0 & 9.96 & 108 \\
\hline Nov & -4.0 & 64.7 & 11.7 & 12.6 & 0 & 10.51 & 114 \\
\hline Dec & -10.8 & 63.1 & $1<.1$ & 12.6 & 0 & 10.96 & 119 \\
\hline Average & 2.8 & 66.4 & 11.3 & 12.6 & 0. & 10.12 & 110 \\
\hline
\end{tabular}

a From Webster (1970).

Other climate-associated impacts on cattle are wind and mud. Wind reduces the animals' coat insulation and has the same effect as lower temperature. Mud and water also decrease the animals' ability to keep warm, and cause it to consume more energy for locomotion.

Fresh water requirements for feed lots are drinking water and equipment washdown. One rancher in Surprise: Valley noted that his cattle drank geothermal water. Of six samples tested in the area, two were essentially potable water quality and four were high in boron, so that the animals would have to be provided with potable water. Potable water needs of cattle are low; one-moderate sized well would supply the large 18,000-animal feedlot analyzed below.

Cattle ranching is currently in the deepest recession in its history. A severely depressed market combined with rapidly escalating costs have created a situation even more serious for cattle ranching than the great depression of the 1930s. In 1975 the cost to keep a cow for one year. was $\$ 219$, while the average return was $\$ 140$ per cow, a loss : of $\$ 79$ per cow. Price predictions, as illustrated below, show a moderate increase over the years 1977 and 1978, but are not sufficient to provide material relief to the ranchers. 
Projected Cattle Prtces, Western U.S., 1976-78 15

Class and Weight

\begin{tabular}{cc} 
CENTS PER POUND \\
\hline 1976 a & 1977
\end{tabular}

$\begin{array}{lrrr}\text { Steer calves }(300-5001 \text { bs. }) & 35-40 & 38-45 & 44-53 \\ \text { Yearling steers (600-800 ibs.) } & 35-40 & 37-42 & 39-45 \\ \text { Utility cows (900-1,100 1bs.) } & 20-26 & 21-27 & 23-30 \\ \text { Choice steers }(1,000-1,100 \text { ibs.) } & 37-40 & 40-46 & 43-52\end{array}$

a/ Fourth quarter of 1975 .

Introduction of geothermal energy as a component in the production of cattle will not materially change the basic economics of the system. Recovery of the market must await firming of an adequate price structure. What geothermal energy can contribute is operation of feedlots in the cold climates of Lassen and Modoc Counties which would not otherwise be practical. If these were operated by large individual ranches or as cooperatives, they would gain the advantages of high production sales and would add the profits of an additional major component in the marketing chain to the hard pressed ranchers.

The profit of a feedlot in these areas must compensate for the added cost of feed shipments, $\$ 2$ to $\$ 3$ per head, and the added cost of shipping heavier animals to market $\$ 3$ to $\$ 4$ per head (400 pound weight gain), for a total of $\$ 5$ to $\$ 7$ per head. A 400 pound weight gain represents $\$ 160$ to $\$ 200$ worth of added animal selling price. If we assume the feedlot makes a profit of 10 percent on the added weight, the $\$ 16$ to $\$ 20$ profit more than covers the shipping penalties.

The cost of adding geothermal warming to a feedlot is only a small part, about four percent, of annual operating costs, but it contributes importantly to feedlot efficiency. Lack of good quantitative data makes the science of est tmating cold weather effects on weight gain tnexact, but a best est tmate (Dr. E. Barmettler) is that warming cattle in the study areas would save about $\$ 41$ per head as follows:

\section{DOLLAR SAVINGS ACHIEVED THROUGH HEATING CATTLE}

\section{Per Head}

Savings in feed

$$
\$ 14 .
$$

Savings in death loss

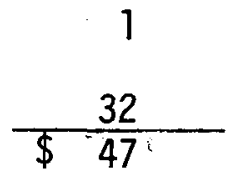

Cost of Geothermal warming system (capital and operating costs)

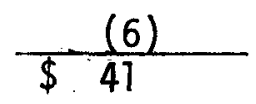

This represents the savings per head in a cold climate feedlot with geothermal heating over one without heat. 
It is estimated that in a large feedlot 1.5 hours of labor are required annually per head. An 18,000-animal feedlot would require a work force of about 10 to 15 personnel.

A winter feedlot in Lassen or Modoc Counties would require a level fenced area with windbreaks for protection from prevailing winds and an area warmed by underground pipes. In addition to providing heat for the cattle, the area would act to evaporate water and snow and reduce mud conditions.

Initially a small feedlot was considered stzed for about 60 head of cattle and suitable for operation by individual small ranchers. The arrangement was based on a Department of Agriculture design 16 with a concrete floor and overhead roof protecion. The arrangement was modified to add wind protection and to provide water heating in the base concrete. But costs for such a system, $\$ 40-\$ 50$ per head, were prohibitive.

A second analysis based on a 55 acre feedlot with a capacity of 9000 head and an 18000 -head per year production rate (2 rotations per year), substantially reduced costs. In this analysis, the overhead protection was deleted and 85 percent of the warming was done under soil and 15 percent under concrete. See Figures $V-9$, and $V-10$. The feedlot was designed for 650-pound feeder steers to be fattened to 1050 pounds over a 135-day feed period. The factlity contains 30. compartments with a capacity of 300 head each.

A summary outline of the pertinent data is as-follows:

\author{
TABLE V-7 \\ COST SUMMARY \\ $(18,000$ head per year feed lot)
}

(1) Per 1b. Cost $\$ / 1 \mathrm{~b}$. gain 400 lbs.

Operations

Feed Costs

Facility

Equipment

Labor

*General Overhead - $2 \%$ -

0.14

0.70

Livestock Costs

18,000 head, 650 lbs. o $35 \phi$ Interest $12 \%$ (6 mo.)

$\frac{0.38}{19.43}$ Death Loss

$1 \%$

21.67

1.30

$\frac{0.22}{23.19}$

TOTAL CASH INVESTED (excluding geothermal costs) (Break-even cost)

42.62

Wells, pumps, Service Lines, etc.

0.48 $12 \%$ interest

0.05

TOTAL COST

43.15

(1) Basis 1050 1b. market weight. 

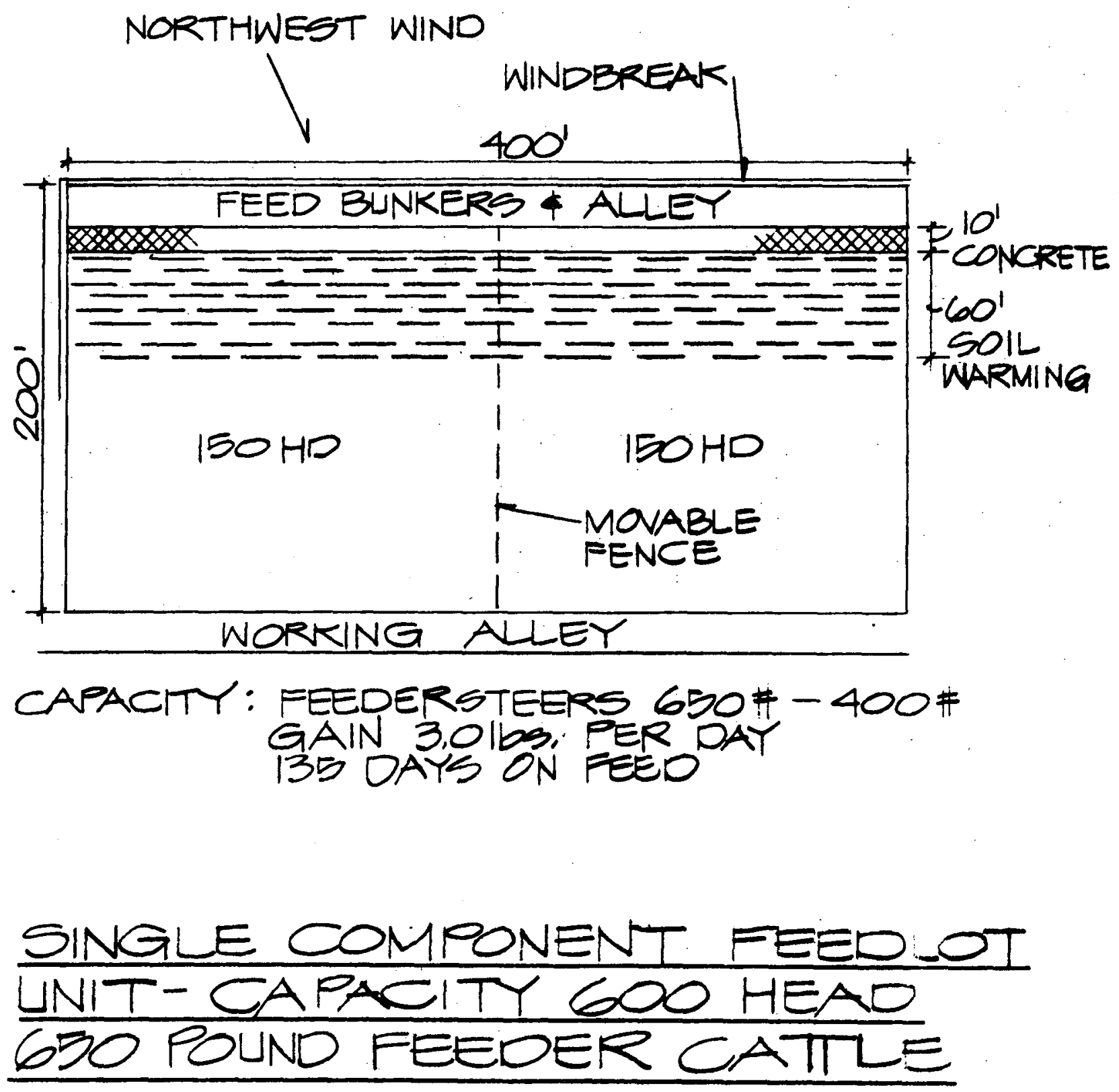

$$
\text { FIC. } \nabla-9
$$

55 


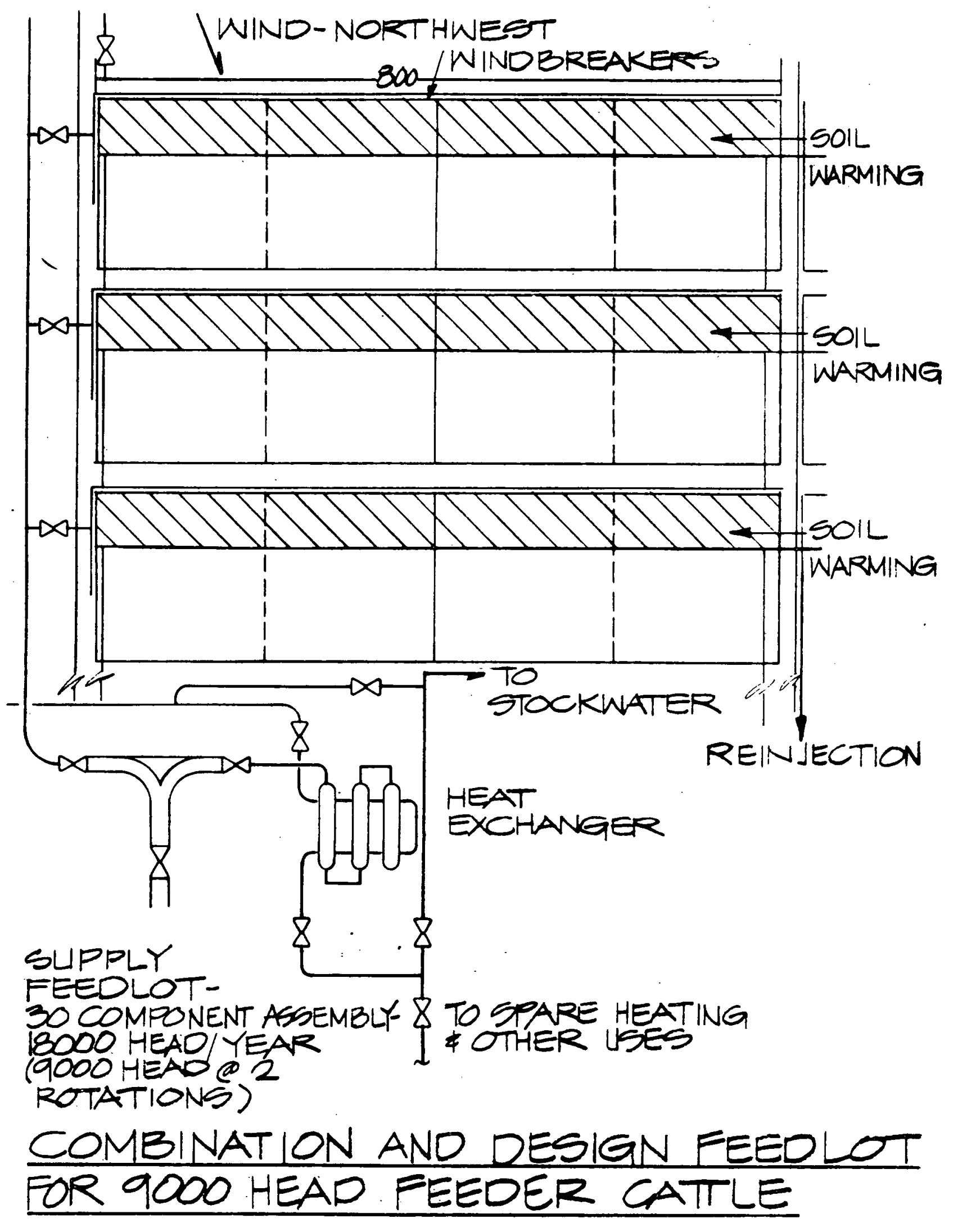

$$
\text { FIG: Z-10 }
$$


of the 3.27 cent per pound cost attributed to facility costs, the cold weather equipment, consisting of the geothermal warming system and windbreaks, contributed 1.50 cents per pound.

\section{Conclusions :}

The use of geothermal energy would increase the efficiency of feedlots located in Lassen or Modoc County. While it would be moderately more costly to build and operate than a feedlot in a warm climate, it could, if operated as a cooperative, provide local ranchers with improved control of marketing operations and provide them the profits from feedlot fattening. 


\section{Aquaculture}

Aquaculture was selected for analys is because it appeared to be ideal for application of geothermal heat. Warm ponds would allow year-round growth of food fish, a large variety of aquatic spectes would be avallable, and large amounts of low cost energy would be required. It appeared that geothermal energy might make practical the introduction of a major new industry to California. Closer analyses showed these presumptions, for the short-term view, to be overly optimistic. The species selected for analysis, while it brought a handsome market price, could not generate enough yield to pay for the heat. Other species, which could be grown at amazingly high yields, would not satisfy public tastes. Of the many varieties of aquatic animals suitable for farming on an industrial basis, several grow best in warm water in the range 65-85 degrees F. Among these are many species of carp, buffalo fish and paddle fish, catfish, labyrinth fishes, Tilapia, frogs, mullet, shrimp and prawns. Several can be grown in brackish water and in very high densities. Bardach $^{19}$ (see Table V-8) lists the aquacultural yields of several selected species.

TABLE V-8

SELECTED EXAMPLES OF AQUACULTURAL YIELDS ARRANGED BY ASCENDING INTENSITY OF CULTURE METHODS

\begin{tabular}{|c|c|c|}
\hline Culture Method & Species & $\begin{array}{l}\text { Yield KG/HA(Year) or } \\
\text { Economic Gain }\end{array}$ \\
\hline \multirow[t]{2}{*}{ Transplantation } & Plaice (Denmark,1919-1957) & $\begin{array}{l}\text { Cost: benefit of transplan- } \\
\text { tation, } 1: 1.1-1.3 \text { in best } \\
\text { years (other social benefits) }\end{array}$ \\
\hline & Pacific salmon (U.S.) & $\begin{array}{l}\text { Cost: benefit, based on re- } \\
\text { turn of hatchery fish in } \\
\text { commercial catch, } 1: 2.3-5.1\end{array}$ \\
\hline \multirow[t]{3}{*}{$\begin{array}{l}\text { Release of reared young } \\
\text { into natural environment }\end{array}$} & Pacific salmon (Japan) & $\begin{array}{l}\text { Cost: benefit } 1: 14-20 \text {, on } \\
\text { above basis }\end{array}$ \\
\hline & $\begin{array}{l}\text { Shrimp, abalone, puffer } \\
\text { fish (Japan) }\end{array}$ & $\begin{array}{l}\text { Not assessed; reputed to } \\
\text { increase income of fishermen }\end{array}$ \\
\hline & $\begin{array}{l}\text { Brown trout (Denmark, } \\
\text { 1961-1963) }\end{array}$ & $\begin{array}{l}\text { Maximum net profit/100 } \\
\text { planted fish: } 163 \%\end{array}$ \\
\hline $\begin{array}{l}\text { Retention in enclosures of } \\
\text { young or juveniles from } \\
\text { wild populations, no fer- } \\
\text { tilization, no feeding }\end{array}$ & $\begin{array}{l}\text { Mullet } \\
\text { Eel, miscell.fish (Italy) } \\
\text { Shrimp (Singapore) }\end{array}$ & $\begin{array}{l}150-300 \\
1,250\end{array}$ \\
\hline $\begin{array}{l}\text { Stocking and rearing in } \\
\text { fertilized enclosures, } \\
\text { no feeding }\end{array}$ & $\begin{array}{l}\text { Milkfish (Taiwan) } \\
\text { Carp and related spp. } \\
\text { (Israel, S.E. Asia) } \\
\text { Tilapia (Africa) } \\
\text { Carp (Java, sewage streams) }\end{array}$ & $\begin{array}{l}1,000 \\
125-700 \\
400-1,200 \\
62,500-125,000\end{array}$ \\
\hline
\end{tabular}


TABLE V-8 (continued) SELECTED EXAMPLES OF AQUACULTURAL YIELDS ARRANGED BY ASCENDING INTENSITY OF
CULTURE METHODS

Culture Method

Stocking and rearing with fertilization and feeding

Intensive cultivation in running water; feeding

Intensive cultivation of sessile organisms, mol-. lusks and algae
Species
Yield KG/HA (year) or Economic Gain

\begin{tabular}{|c|c|c|}
\hline & $\begin{array}{l}\text { Tilapia (Cambodia) } \\
\text { Carp and related spp. (in } \\
\text { polyculture--China, Hong } \\
\text { Kong, Malaysia) } \\
\text { Clarias (Thailand) }\end{array}$ & $\begin{array}{l}8,000-12,000 \\
3,000-5,000 \\
97,000\end{array}$ \\
\hline $\begin{array}{l}\text { Intensive cultivation in } \\
\text { running water; feeding }\end{array}$ & $\begin{array}{l}\text { Rainbow trout (U.S.) } \\
\text { Carp (Japan) } \\
\text { Shrimp (Japan) }\end{array}$ & $\begin{array}{l}2,000,000(170 \mathrm{~kg} / 1 \mathrm{iter}-\mathrm{sec})^{\mathrm{b}} \\
1,000,000 \text { (about } 100 \mathrm{~kg} / 1 \text { iter- } \\
\mathrm{sec} \text { ) } \\
6,000\end{array}$ \\
\hline $\begin{array}{l}\text { Intensive cultivation of } \\
\text { sessile organisms, mol-. } \\
\text { lusks and algae }\end{array}$ & $\begin{array}{l}\text { Oysters (Japan, Inland Sea) } \\
\text { Oysters (U:S.) } \\
\text { Mussels (Spain) } \\
\text { Porphyra (Japan) } \\
\text { Undaria (Japan)a } \\
\end{array}$ & $\begin{array}{l}20,000 \\
5,000 \text { (best yields) } \\
300,000 \\
7,500 \\
47,500\end{array}$ \\
\hline
\end{tabular}

a Raft-culture calculations based on an area $25 \%$ covered by rafts.

$b$ See text for volume of flow versus surface as basis of yield.

Of the suitable aquatic species available, Macrobrachium rosenbergii, a giant freshwater prawn native to Southeastern Asia, was selected for analysis. This prawn has been successfully cultured in the orient since $1969^{20}$ and today is being raised in ponds in Florida, Hawaii, California, Puerto Rico and Panama and in the warm water effluent from a power plant in New Jersey. The current literature $19,20,21,22,23,24$ is replete with descriptive studies and analytical research on this animal. The principal reason for selecting it, however, was its high degree of marketability compared to most other aquatic food fish. On today's market, shrimp are sold retail at prices from three dollars per pound for small to over six dollars per pound for the larger species. Macrobracium rosenbergii would fall in the latter category and be marketed at between three and six to the pound.

The case against the common carp, at least for the short-term, and other similar highly nutritional fishes, is stated succinctly by Bardach et al 19: 


\begin{abstract}
"Price and prejudice went hand in hand, so that today in Morth America carp bring only a third the price of such comparable 'rough" fish as buffalo fish. Some carp are marketed by commercial fisherman, but sales are virtually limited to the poorest members of society.
\end{abstract}

With the continued eutrophication of American waters and the predicted narrowing of the gap between protein supply and demand, sport and commercial fishermen, fish culturists, and housewives may all have to reconsider the carp. For the present, however, carp are scarcely considered edible in North America and their culture is not economically feasible."

Maximum length for Macrobrachium rosenbergii is about $25 \mathrm{~cm}$ for males and $15 \mathrm{~cm}$ for females. Both sexes bring extremely high prices relatfve to other fish. In nature adult Macrobrachium rosenbergii are found in virtually all types of fresh and brackish water. Larval development, however, requires 8 to 22 percent salinity 19 . In nature a single female may spawn three to four times each year, producing up to 120,000 eggs each time. Incubation requires $26^{\circ} \mathrm{C}$ $\left(78.8^{\circ} \mathrm{F}\right)$ to $28^{\circ} \mathrm{C}\left(82.3^{\circ} \mathrm{F}\right)$. Over a period of 35 to 55 days, the larvae pass through 12 stages and metamorphose into juveniles. Juveniles adopt a benthic mode of life and feed on benthic animals and organic detritus.

During their early life the larvae diet is specific; they are fed brine shrimp nauplii. As they metamorphose to juveniles, their diets change and vitaminfortified mixtures of fish flesh and egg custard, powdered dried chicken blood and phytoplanklon have all been successfully used. The growing juveniles can be fed fresh fish, mollusks and earthworms cut into pieces according to the size of the juveniles. These can be supplemented with dried animal matter, grain, peas, beans and soft aquatic plants. Use of prepared feeds requires that uneaten food and fecal matter be siphoned out daily and that the water be changed frequently.

When they reach about four $\mathrm{cm}$ in length, the young prawns are suitable for stocking in fresh water ponds. "Almost any sort of pond over $200 \mathrm{~m}^{2}$ - in surface area and $50 \mathrm{~cm}$ in depth, with a water temperature of 22 to $32^{\circ} \mathrm{C}\left(71: 6\right.$ to $\left.89.6^{\circ} \mathrm{F}\right)$ can be used for growing Macrobrachium rosenbergii, but larger ponds, 1000 sguare meters or more in area and 1 to 1.5 , meters deep, are more economica 1. "19

Prawns may be stocked alone or in combination with fish (see Table $19 \mathrm{~V}-9$ ). Knight, however, recommends that initial adventures into prawn aquaculture be limited to. single species in small ponds to prevent the spreading of communicable deseases. Natural production within the ponds should. supply most of the food. Supplementary foods can include cow dung mixed with 1 ime, animal matter, fish, mollusks, earthworms, offal, live insects, various grains and rotten fruit. Five percent of the total body weight of prawns should be fed daily. 
Finter $\forall-9$

STOCKING RATES FOR GIANT FRESHATER PRAMUS (macrobrachium rosenbergi i) CULTURED AND WITH FISH IN SOUTHEAST ASIA

\begin{tabular}{lcc}
\hline Pond Conditions & $\begin{array}{c}\text { Stocking Rate } \\
(\text { Prawns } / H A)\end{array}$ & $\begin{array}{c}\text { Stocking Rate } \\
\text { of Fish }\end{array}$ \\
\hline
\end{tabular}

Rich

Medium

Poor

Rich

Medium

Poor
Prawns Cultured Alone

15,000

10,000

6,000

Prawns Cultured With Fish

$\begin{array}{rr}6,000 & \text { Full } \\ 12,000 & \text { Half } \\ 4,000 & \text { Full } \\ 8,000 & \text { Half } \\ 2,000 & \text { Full } \\ 4,000 & \text { Half }\end{array}$

Two problems generally encountered in prawn culture are oxygen depletion and cannibalism. Normally, sufficient oxygen can be provided if the throughput is high and if the water is aerated over a rough surface before it enters the pond. When oxygen becomes deficient the prawns migrate to the edges of the ponds and their activity becomes sluggish. Prawns are cannibalistic, more so when overcrowded. They are especially vulnerable when moulting. When a number of females are kept in a tank, a male, if present, will protect a moulting female from attack. One male can protect five or six females 22 . Cannibalism is also reduced by providing natural hiding places by growing small patches of Ipomoea in the pond (10 percent maximum pond coverage) and by placing branches on the bottom of the pond.

Macrobrachium rosenbergi $i$ were experimentally reared through all larvel stages by Ling and Merican at Penang, Malaysia, and later by Fujimura in Hawaij22.

Currently prawn aquaculture research and development and pilot-scale activities in the U.S. are underway in Hawai i, California, Florida, North Carolina and elsewhere.

Knight $^{25}$ noted that raising prawns is complex and not for the amateur. He recommended that an entrepreneur, before deciding to invest in prawn aquaculture, should be ready to operate without profit during the first two years. During this time period, he would require professional training and would learn the many nuances of this sophisticated business necessary to bring a successful crop to market. He also recommended that geothermal water be used as an indirect heat source and that only potable water be used in direct contact with the prawns so that dangers of disease and concentration of dangerous chemicals in the animals' organs be minimized. Goodwin and Hanson 22 also warned of deposits of calcium carbonate from saline solutions on the prawn carapace at high $\mathrm{pH}$. However, Johnsor-20 at the Oregon Institute of Technology, is experimenting with direct use of geothermal water.with some success. 
Disease generally is not considered a major obstacle to prawn culture. 22 Wipeouts can be reduced or eliminated by alertness of the operator in reporting diseases to a pathologist to identify cures and provide preventive measures.

\section{Pond Production}

After accounting for the shorter growing season in South Carolina it may be seen that annual. production rates for different. locations are similar:

PRAWN (Macrobrachium rosenbergii)PRODUCTION RATES

Location

South Carolina

Hawa i i

Ota's Ponds

Kato's Fish Farms
Ref.

23

22
Production Rate (annual)

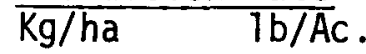

(1) $1000-2000 \quad 890-1790$

(2) $3360 \quad 3000$ $3240 \quad 2890$

(1) When stocked with large juveniles of $.25 \mathrm{gm}$ or greater weight; five-six month growing season.

(2) Stocking rate of 1.5 juveniles per square foot.

With geothermal energy enabling ideal temperature conditions year-round, one would anticipate greater yields than those tabulated.

\section{Marketing}

Prawns would probably move into markets with other high value crustaceans such as lobsters, crabs and shrimp. Currently, they are mostly sold as whole animals with heads on, but for stronger competition they would probably be sold as tails and could be marketed in sizes from those comparable to Gulf coast shrimp to larger sizes, four to six to the pound.

Hawaitan experience indicates the cost of raising prawns to marketable size is about two dollars per pound. 22 Feed costs were about 42 cents. Labor costs ran 30 to 40 percent of grow-out costs. Approximate costs estimated from various data sources (1974) are listed below.

\section{APPROXIMATE COSTS OF RAISING PRAWNS}

$\$$ per pound of Product

Feed

$$
\$ .40-\$ .50
$$

Labor

$$
\$ .60-\$ .80
$$

Stock (Larvae)

$$
\$ .06-\$ .10
$$

Operating Cost

$$
\$ 1.00-\$ 1.40
$$

Capital costs in Puerto Rico ${ }^{22}$ ran 3,556 dollars per acre based on 36 one-acre ponds, each on 1.5 acres of land. 
It was initialiy presumed that application of geothermal energy to prawn aquaculture would increase capital costs but allow higher operating efficiency through ideal temperature control of the water and year-round growing season in Lassen and Modoc Counties. Analys is proved this presumption false.

Figure V-11 illustrates a flow chart for geothermally heated ponds. It is based on a one-acre by three foot deep pond, $20^{\circ} \mathrm{F}$ air temperature with a wind velocity of five miles per hour. A windbreak is located alongside to prevent heat, losses during high wind periods. Nevertheless, preliminary design heat loss calculations indicate losses will be quite high, so that durjng cold weather each acre of pond requires one. well supplying $260 \mathrm{gpm}$ at $200^{\circ} \mathrm{F}$. Heating costs would amount to about 10,000-15,000 dollars per year, including the cost of the potable water heaters and the supply and reinjection wells. Based on production rates in Hawaii, say 3000 pounds per acre, this would amount to three to five dollars per pound of product, too high a cost to justify the use of geothermal energy. The cost of conventional fuel would be 30 to 40 dollars a pound. Use of a low cost air supported cover of the ponds to reduce energy losses was considered, but the high condensation rates left technical feasibility in doubt and the cost of the cover exceeded the energy savings.

The only conclusion that can be drawn is that prawn aquaculture is not profitable enough to support even an inexpensive heating system in Lassen or Modoc Counties. Until the intensity of prawn production can be increased by nearly an order of magnitude (while maintaining market prices), geothermal energy cannot be economically applied.

Other aquatic species, i.e., carp, have yielded 0.9 to 3.6 million pounds per acre; but as was shown by Bardach ${ }^{19}$, the American market is not yet ready.

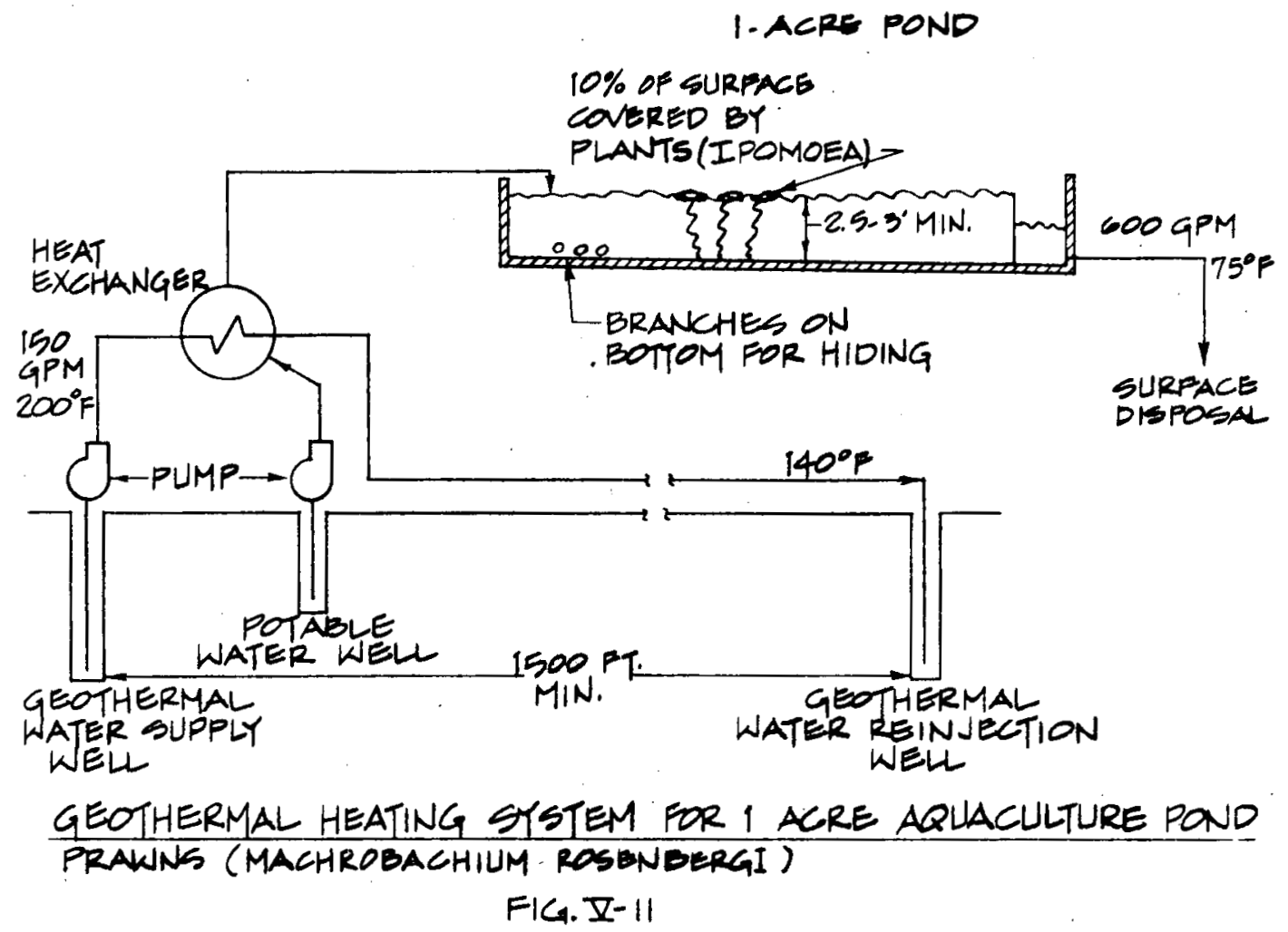


More recent evidence that the palate of Americans has not changed is evidenced in an article in The Wall Street Journa1, dated September 20, 1976, and misleadingly titled "Freshwater-Rough Fish Are Winning More Acceptability on U.S. Dinner Tables." The article cites prices at a major Chicago fish market as follows: Popular varieties of fish--Whitefish and Red Snapper, $\$ 1.25$ a pound; filleted yellow perch, $\$ 3.50$ a pound. Rough fish varieties (i.e., warm water fish), boned buffalo fish, 45 cents a pound; sheepshead, 20 to 25 cents a pound; and carp, 10 to 12 cents a pound. The article goes on to say that a large cannery that so far has rejected the bait is Libby, McNeil \& Libby, Inc. It decided against canning carp and tuna-type products because it projected high promotional and advertising costs."

Channel catfish, considered a delicacy in the southeastern states, is another warm water fish which has potential. Bardach 19 (1972) notes that, "Present indications are that economic prognosis for new catfish farmers is getting poorer," but changing markets and more efficient production through use of geothermal water might alter this.

The case for geothermally heated aquacultural products should not be closed, however. The marketing views presented here were based on the assumption that geothermal water could not be used in direct contact with aquatic animals and considered only food products for human consumption in the United States. Direct growth in geothermal water, if proven safe, would bring about a large reduction in production costs. Changes in tastes for species which can be intensively grown could provide a major new market. Production for overseas human consumption or for local use as fertilizers or animal feeds are alternatives which have potential but which were not analyzed.

Over the long run, the ability of aquacultural systems to efficiently generate high quantities of high quality low cost protein is certain to predominate over temporary whims of palate. The capability of such systems to consume waste in symbiotic biological group, i.e., manure for fish feed generated in a geothermal multi-use arrangement with a feedlot and downstream fish pond, could provide additional efficiencies and ease environmental disposal problems. 
APPENDIX

$\theta$ 
- APPENDIX

\author{
Demographic and Economic Profile \\ Modoc and Lassen Counties
}

\title{
Population
}

Historical population levels have shown erratic trends in both counties. Table shows historical population for both counties for decadal periods, 1920-1970.

Table A-1

Historical Population

Modoc and Lassen Counties

\begin{tabular}{|c|c|c|c|c|c|c|c|}
\hline & 1920 & 1930 & 1940 & 1950 & 1960 & 1970 & $1976^{\mathrm{E}}$ \\
\hline $\begin{array}{l}\text { Modoc } \\
\text { Lassen }\end{array}$ & $\begin{array}{l}5,425 \\
8,507 \\
\end{array}$ & $\begin{array}{r}8,038 \\
12,589 \\
\end{array}$ & $\begin{array}{r}8,713 \\
14,479 \\
\end{array}$ & $\begin{array}{r}9,678 \\
18,474 \\
\end{array}$ & $\begin{array}{r}8,308 \\
13,597 \\
\end{array}$ & $\begin{array}{r}7,469 \\
14,960 \\
\end{array}$ & $\begin{array}{r}8,400 \\
17,000 \\
\end{array}$ \\
\hline Total & 13,932 & 20,627 & 23,192 & 28,152 & 21,905 & 22,429 & 25,400 \\
\hline
\end{tabular}

The significant decline in population in the 1950's is attributed to economic reasons. The large emigration that occurred was in direct response to the lack of jobs in both counties. Recent growth has been urban in nature, and is generally indicative of a growing retirement age population.

The losses in population have occurred mostly in labor age groups. Tables 2 and 3 show the relative change in different population age groups for both counties. It is also interesting to note that the population group 20-24 increased dramatically in Lassen County between 1960 and 1970--an indication of the shift of young persons mainly from cities to rural areas. 
TABLE A- 2

MODOC COUNTY POPULATION BY AGE GROUPINGS 1950,1960 and 1970

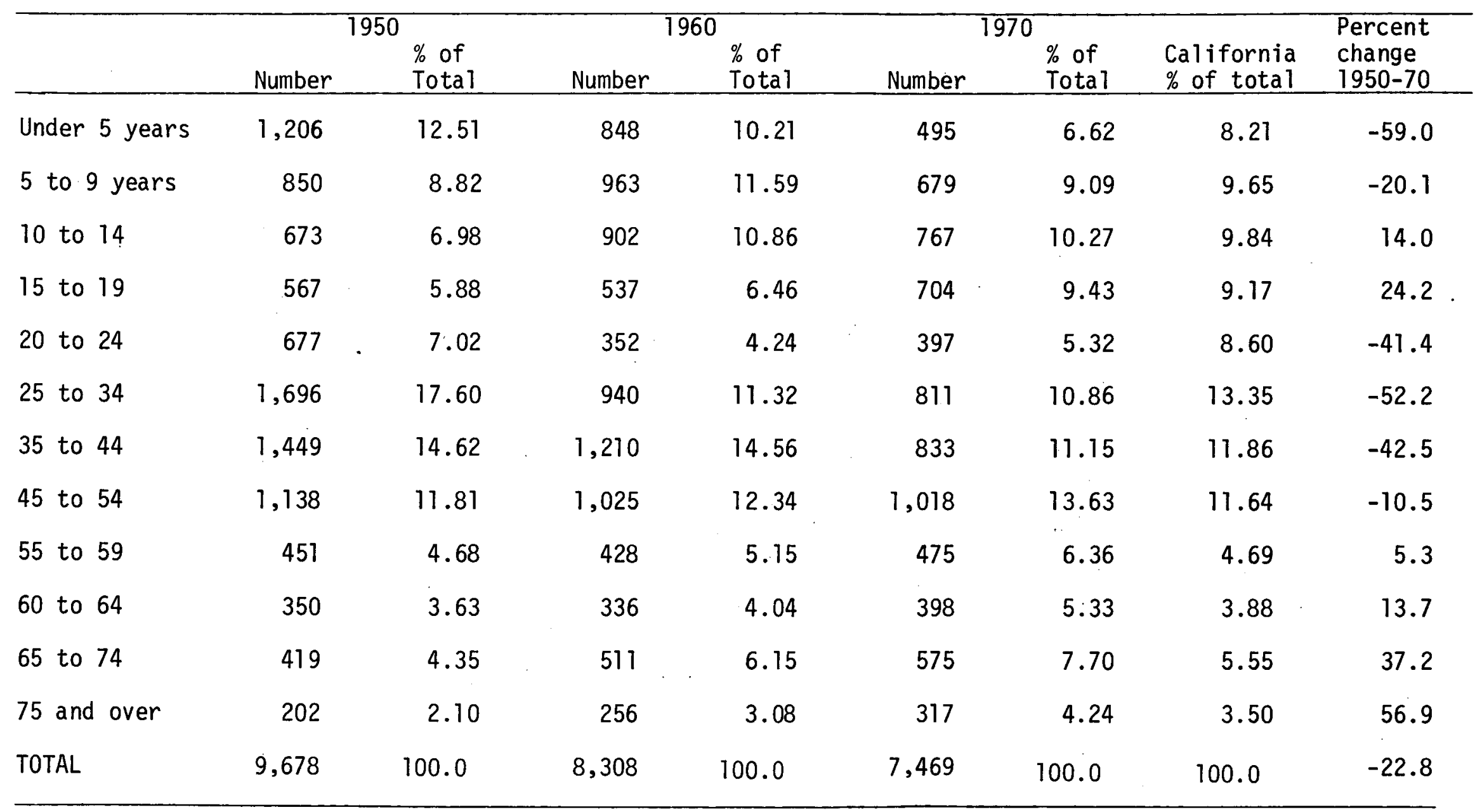

Source: U.S. Bureau of the Census, U.S. Census of Population, 1950, 1960 and 1970, California General Social and Economic Characteristics. 


\section{TABLE $A-3$}

LASSEN COUNTY POPULATION

BY AGE GROUPINGS

1950,1960 and 1970

\begin{tabular}{|c|c|c|c|c|c|c|c|}
\hline & & & & & & & Percent \\
\hline & Number & $\begin{array}{l}\% \text { of } \\
\text { Total }\end{array}$ & Number & $\begin{array}{l}\% \text { of } \\
\text { Total }\end{array}$ & Number & $\begin{array}{l}\% \text { of } \\
\text { Total }\end{array}$ & $\begin{array}{l}\text { change } \\
1950-70\end{array}$ \\
\hline Under 5 years & 2,370 & 12.8 & 1,394 & 10.3 & 1,152 & 7.7 & -57.4 \\
\hline 5 to 9 years & 1,834 & .9 .9 & 1,477 & 10.9 & 1,340 & 9.0 & -26.9 \\
\hline 10 to 14 & 1,465 & 7.9 & 1,443 & 10.6 & 1,571 & 10.5 & 7.2 \\
\hline 15 to 19 & 1,288 & 7.0 & 958 & 7.0 & 1,490 & 9.9 & 15.7 \\
\hline 20 to 24 & 1,405 & 7.6 & 583 & 4.3 & 1,089 & 7.3 & -22.5 \\
\hline 25 to 34 & 3,111 & 16.8 & 1,580 & 11.6 & 1,631 & 10.9 & -47.6 \\
\hline 35 to 44 & 2,685 & 14.6 & 1,925 & 14.2 & 1,825 & 12.2 & -32.0 \\
\hline 45 to 54 & 1,969 & 10.7 & 1,745 & 12.8 & 1,970 & 13.2 & 0.1 \\
\hline 55 to 59 & 723 & 3.9 & 667 & 4.9 & 846 & 5.6 & 17.0 \\
\hline 60 to 64 & 629 & 3.4 & 592 & 4.4 & 688 & 4.6 & 9.4 \\
\hline 65 to 74 & $\cdot 707$ & 3.8 & 862 & 6.3 & 869 & 5.8 & 22.9 \\
\hline 75 and over & 288 & 1.6 & 371 & 2.7 & 489 & 3.3 & 69.8 \\
\hline Tota 1 & 18,474 & 100.0 & 13,597 & 100.0 & 14,960 & 100.0 & -19.0 \\
\hline
\end{tabular}

Source: U.S. Bureau of the Census, U.S. Census of Population 1950, 1960 and 1970, California General Social and Economic Characteristics. 


\section{Employment}

In 1970, the greatest area of employment in both Lassen and Modoc Counties was the service sector, with 76.4 and 58.6 percent of the total employment population providing service jobs, respectively. Of significance, service jobs have increased most rapidly of all occupations, while farming and manufacturing employment has declined substantially. The gain in service employment has been almost entirely governmental. Tables 4 and 5 show employment by occupation for Modoc and Lassen Counties, respectively, by decade since 1950.

Employment in both counties is highly seasonal, with wide variations between high summer and low winter employment. The categories of employment accounting for the major portion of this difference are related to seasonal demands in the lumber and agriculture industries. Annual unemployment rates since 1960 are shown in Table 6 for both counties. There has been a marked increase in unemployment since 1970. In early 1975 the unemployment rate was a staggering 26.4 percent. This tremendous seasonality reflects the severe degree of underemployment in the region.

Major employment cutbacks in the Sierra Army Depot and significant Tumber market fluctuations beginning in about 1973 had a major effect on the unemployment rate of Lassen County. The lower unemployment rates in Modoc County are primarily due to the county's larger agricultural base, and lesser dependence on the lumber industry compared to that of Lassen County. The increase in unemployment in Modoc County during 1976 was the result of market demand and drought effects.

Tables 7 and 8 del ineate experience information on those unemployed in 1972 by occupation. A large percentage of the total unemployed are classified as craftsman, foremen and kindred workers. Total blue collar workers for both counties constitute about 60 percent of the unemployed work force. 


\section{TABLE A-4}

MODOC COUNTY EMPLOYMENT BY MAJOR CATEGORIES

1950,1960 and 1970

(1950)

(1960)

(1970)

$\begin{array}{ccccc}\text { Number } & \% \text { Employed } \% \text { Employed } & \text { of Total. of Total Number } & \% \text { of Toyed \% Employed } & \text { \% Employed \% Employed } \\ \text { Employed Employment Population Employed Employment Population Employed Employment Population }\end{array}$

\begin{tabular}{|c|c|c|c|c|c|c|c|c|c|}
\hline $\begin{array}{l}\text { Agriculture } \\
\text { Forestry \& } \\
\text { Fisheries }\end{array}$ & 1,194 & $32.0 \%$ & 12.3 & 998 & $37.3 \%$ & $12.0 \%$ & 772 & $26.5 \%$ & $10.3 \%$. \\
\hline $\begin{array}{l}\text { Mining \& } \\
\text { Construction }\end{array}$ & 276 & $7 .: 4 \%$ & 2.9 & 182 & $5.7 \%$ & $2.2 \%$ & 179 & $6.1 \%$ & $2.4 \%$ \\
\hline Manufacturing & 739 & $19.8 \%$ & 7.6 & 393 & $12.3 \%$ & $4.7 \%$ & 257 & $8.8 \%$ & $3.4 \%$ \\
\hline Service & 1,526 & $40.8 \%$ & 38.6 & 1,611 & $50.7 \%$ & $19.4 \%$ & 1,709 & $58.6 \%$ & $22.9 \%$ \\
\hline $\begin{array}{l}\text { Total } \\
\text { Employment }\end{array}$ & 3,735 & $100.0 \%$ & 61.4 & 3,184 & $100.0 \%$ & $38.3 \%$ & 2,917 & $100.0 \%$ & $39.0 \%$ \\
\hline $\begin{array}{l}\text { Total } \\
\text { Population }\end{array}$ & 9,678 & & & 8,308 & & & 7,469 & & \\
\hline
\end{tabular}

Source: 1950,1960 and 1970 data are from U.S. Census of Population. 
TABLE $A-5$

LASSEN COUNTY EMPLOYMENT BY MAJOR CATEGORIES

1950,1960 and 1970

(1950)

\% Employed \% Employed

Number of Total of Total

Employed
(1960)

(1970)

\% Employed \% Employed of Total of Total

Employment Population Employed
\% Employed \% Employed of Total of Total Agriculture, Forestry and Fisheries 705

10.7

3.8

562

11.7

4.1

528

10.1

3.5

Mining and

Construction

234

3.6

1.3

190

4.0

3.1

226

4.3

1.5

Manufacturing 1,997

30.4

10.8

893

18.7

2.1

483

9.2

3.2

Service

3,633

55.3

19.7

3,133

65.6

25.9

3,995

76.4

26.7

Total

Employment

$6,569 \quad 100.0$

35.6

4,778

100.0

35.2

5,232

100.0

34.9

\section{Total}

Population $\quad 18,474$

13,597

14,960

Source: 1950,1960 and 1970 data are from U.S. Census of Population. 
TABLE $A-6$

HISTORICAL UNEMPLOYMENT RATES (\%)

MODOC AND LASSEN COUNTIES

\begin{tabular}{|c|c|c|c|c|c|c|c|}
\hline \multirow[t]{2}{*}{ YEAR } & \multicolumn{3}{|c|}{ MODOC } & \multicolumn{3}{|c|}{ LASSEN } & \multirow{2}{*}{$\begin{array}{l}\text { CALIF. } \\
\text { YearTy } \\
\text { Average }\end{array}$} \\
\hline & Low & $\begin{array}{l}\text { Yearly } \\
\text { Average }\end{array}$ & $\mathrm{High}$ & Low & $\begin{array}{l}\text { Yearly } \\
\text { Average }\end{array}$ & High & \\
\hline 70 & $3.8(0 c t)$ & 6.7 & 11.5 (Dec) & $6.5(0 c t)$ & 10.9 & 16.1 (Feb) & 7.3 \\
\hline 1971 & 3.7 (Sept) & 7.9 & 14.3 (Jan) & 7.4 (Sept) & 11.4 & 18.1 (Mar) & 8.8 \\
\hline 1972 & 3.6 (Aug) & 7.1 & $15.3($ Feb) & 7.0 (0ct) & 11.5 & 18.5 (Jan) & 7.6 \\
\hline 973 & 5.9 (Aug) & 9.7 & 14.1 (Dec) & 8.7 (Sept) & 16.9 & 25.7 (Feb) & 7.0 \\
\hline 974 & $7.3(\mathrm{Ju} 1)$ & 10.5 & 14.7 (Jan) & 10.2 (0ct) & 17.4 & 25.2 (Feb) & 7.3 \\
\hline 75 & $7.8(0 c t)$ & 11.9 & 17.6 (Feb) & 13.3 (Sept) & 19.8 & 26.4 (Feb) & 9.9 \\
\hline 1976 & 8.8 (May) & $12^{E}$ & 17.3 (Jan) & 11.1 (Ju1) & $19^{E}$ & 26.0 (Feb) & $8.0^{E}$ \\
\hline
\end{tabular}

Source: State of California, Employment Development Department, Employment, Data and Research Division 


\begin{tabular}{|c|c|c|}
\hline Experienced Unemployed Population & Total & $\begin{array}{l}\% \text { of Total } \\
\text { Experienced Unemployed }\end{array}$ \\
\hline $\begin{array}{l}\text { Total All Occupations - Both Sexes } \\
\text { White Collar Occupations - Total } \\
\text { Professional, Technical and } \\
\text { Managerial Workers } \\
\text { Sales Workers } \\
\text { Clerical Workers } \\
\text { Blue Collar Occupations - Total } \\
\text { Craftsmen, Foremen and Kindred } \\
\text { Workers } \\
\text { Operatives including transport } \\
\text { Laborers Except Farm } \\
\text { Farm Occupations } \\
\text { Service Occupations - Total } \\
\text { Service Workers Except Private } \\
\text { Household } \\
\text { Private Household Workers }\end{array}$ & $\begin{array}{r}171 \\
36 \\
\\
22 \\
0 \\
14 \\
103 \\
57 \\
23 \\
23 \\
11 \\
21 \\
21 \\
0\end{array}$ & $\begin{array}{r}100.0 \\
21.0 \\
12.9 \\
0 \\
8.2 \\
60.2 \\
33.3 \\
13.5 \\
13.5 \\
6.4 \\
12.3 \\
12.3 \\
0\end{array}$ \\
\hline $\begin{array}{l}\text { Total All Occupations - Male } \\
\text { White Collar Occupations - Total } \\
\text { Professional, Technical and } \\
\text { Managerial Workers } \\
\text { Sales Workers } \\
\text { Clerical Workers } \\
\text { Blue Collar Occupations - Total } \\
\text { Craftsmen, Foremen and Kindred } \\
\text { Workers } \\
\text { Operatives including transport } \\
\text { Laborers Except Farm } \\
\text { Farm Occupations } \\
\text { Service Occupations - Total } \\
\text { Service Workers Except Private } \\
\text { Household } \\
\text { Private Household Workers }\end{array}$ & $\begin{array}{r}121 \\
16 \\
16 \\
0 \\
0 \\
90 \\
57 \\
14 \\
19 \\
17 \\
4 \\
4 \\
4 \\
0\end{array}$ & $\begin{array}{r}70.8 \\
9.4 \\
9.4 \\
0 \\
0 \\
0 \\
52.6 \\
33.3 \\
8.2 \\
11.1 \\
6.4 \\
2.3 \\
2.3 \\
0\end{array}$ \\
\hline $\begin{array}{l}\text { Total All Occupations - Female } \\
\text { White Collar Occupations - Total } \\
\text { Professional, Technical and } \\
\text { Managerial Workers } \\
\text { Sales Workers } \\
\text { Clerical Workers } \\
\text { Blue Collar Occupations - Total } \\
\text { Craftsmen, Foremen and Kindred } \\
\text { Workers } \\
\text { Operatives Including Transport } \\
\text { Laborers Except Farm }\end{array}$ & $\begin{array}{r}50 \\
20 \\
\\
6 \\
0 \\
14 \\
13 \\
\\
0 \\
9 \\
4\end{array}$ & $\begin{array}{r}29.2 \\
11.7 \\
3.5 \\
0 \\
8.2 \\
7.6 \\
\\
0 \\
5.3 \\
2.3\end{array}$ \\
\hline
\end{tabular}




\begin{tabular}{|c|c|c|}
\hline Experienced Unemployed Population & Tota $]$ & $\begin{array}{c}\% \text { of Total } \\
\text { Experienced Unemployed }\end{array}$ \\
\hline $\begin{array}{l}\text { Total All Occupations - Both Sexes } \\
\text { White Collar Occupations - Total } \\
\text { Professional, Technical and } \\
\text { Managerial Workers } \\
\text { Sales Workers } \\
\text { Clerical Workers } \\
\text { Blue Collar Occupations - Total } \\
\text { Craftsmen, Foremen and Kindred } \\
\text { Workers } \\
\text { Operatives Including Transport } \\
\text { Laborers Except Farm } \\
\text { Farm Occupations } \\
\text { Service Occupations - Total } \\
\text { Service Workers Except private } \\
\text { Household } \\
\text { Private Household Workers }\end{array}$ & $\begin{array}{r}663 \\
117 \\
44 \\
9 \\
64 \\
424 \\
154 \\
76 \\
194 \\
27 \\
90\end{array}$ & $\begin{array}{r}100.0 \\
17.6 \\
6.6 \\
1.4 \\
9.6 \\
63.9 \\
23.2 \\
11.5 \\
29.3 \\
4.1 \\
13.5 \\
11.5 \\
2.1\end{array}$ \\
\hline $\begin{array}{l}\text { Total All Occupations - Male } \\
\text { White Collar Occupations - Total } \\
\text { Professional, Technical and } \\
\text { Managerial Workers } \\
\text { Sales Workers } \\
\text { Clerical Workers } \\
\text { Blue Collar Occupations - Total } \\
\text { Craftsmen, Foremen and Kindred } \\
\text { Workers } \\
\text { Operatives Including Transport } \\
\text { Laborers Except Farm } \\
\text { Farm Occupations } \\
\text { Service Occupations - Total } \\
\text { Service Workers Except Private } \\
\text { Household } \\
\text { Private Household Workers }\end{array}$ & $\begin{array}{r}470 \\
34 \\
18 \\
0 \\
16 \\
395 \\
144 \\
71 \\
180 \\
22 \\
19 \\
19 \\
0\end{array}$ & $\begin{array}{r}70.9 \\
5.1 \\
\\
2.7 \\
0 \\
2.4 \\
59.6 \\
\\
21.7 \\
10.7 \\
27.7 \\
3.3 \\
2.7 \\
2.7 \\
0\end{array}$ \\
\hline $\begin{array}{l}\text { Total All Occupations - Female } \\
\text { White Collar Occupations - Total } \\
\text { Professional, Technical and } \\
\text { Managerial Workers } \\
\text { Sales Workers } \\
\text { Clerical Workers } \\
\text { Blue Collar Occupations - Total } \\
\text { Craftsmen, Foremen and Kindred } \\
\text { Workers } \\
\text { Operatives Including Transport } \\
\text { Laborers Except Farm }\end{array}$ & $\begin{array}{r}193 \\
83 \\
\\
26 \\
9 \\
48 \\
29 \\
10 \\
5 \\
14\end{array}$ & $\begin{array}{r}29.1 \\
12.5 \\
3.9 \\
1.4 \\
7.2 \\
4.4 \\
1.5 \\
.7 \\
2.7\end{array}$ \\
\hline
\end{tabular}




\section{Income}

Family income for both counties and California for the years 1950, 1960 and 1970 are shown in Tables 9 and 10. The median family income for both counties in 1950 was about the statewide average, however by 7970 both counties had fallen behind the statewide average. Tables 11 and 12 show personal income by major source. Wages and salaries remain the greatest source of income; however, transfer payments (Social Security, pensions or annuity incomes) have steadily increased in Lassen County, but have only remained constant in Modoc County. 
Table $A=9$

FAMILY INCOME: LASSEN COUNTY AND CALIFORNIA, 1950, 1960 and 1970

\begin{tabular}{|c|c|c|c|c|c|c|}
\hline & & en Count & & & Californ & \\
\hline & 1950 & 1960 & 1970 & 1950 & 1960 & 1970 \\
\hline & & & $\underline{\text { Nun }}$ & & & \\
\hline All Families & 4,590 & 3,577 & 4,175 & $2,827,110$ & $5,559,955$ & $5,001,255$ \\
\hline Under $\$ 1,000$ & 230 & 105 & 55 & 260,650 & 525,707 & 111,268 \\
\hline$\$ 1,000$ to $\$ 1,999$ & 295 & 211 & 98 & 302,055 & 569,390 & 116,312 \\
\hline$\$ 2,000$ to $\$ 2,999$ & 740 & 204 & 184 & 437,560 & 434,146 & 176,746 \\
\hline$\$ 3,000$ to $\$ 3,999$ & 1,480 & 270 & 212 & 581,615 & 454,351 & 215,158 \\
\hline$\$ 4,000$ to $\$ 4,999$ & 710 & 480 & 209 & 408,545 & 501,403 & 222,202 \\
\hline$\$ 5,000$ to $\$ 5,999$ & 390 & 602 & 287 & 267,860 & 559,411 & 242,986 \\
\hline$\$ 6,000$ to $\$ 6,999$ & 205 & 470 & 284 & 159,990 & 530,240 & 264,960 \\
\hline$\$ 7,000$ to $\$ 7,999$ & ) & 303 & 330 & ) & 441,639 & 293,660 \\
\hline$\$ 8,000$ to $\$ 8,999$ & 295 & 276 & 329 & $\hat{1} 181,975$ & 355,633 & 312,881 \\
\hline$\$ 9,000$ to $\$ 9,999$ & ) & 214 & 402 & ) & 274,836 & 311,639 \\
\hline$\$ 10,000$ to $\$ 14,999$ & ) & 395 & 1,095 & ) & 635,785 & $1,398,973$ \\
\hline$\$ 15,000$ to $\$ 24,999$ & 125 & 26 & 598 & ) 101,845 & 199,323 & $1,029,394$ \\
\hline$\$ 25,000$ and over & ) & 21 & 92 & ) & 78,091 & 305,076 \\
\hline Unreported & 120 & -- & -- & 125,015 & & \\
\hline Median income & & & & & & \\
\hline Families & $\$ 3,602$ & $\$ 5,861$ & $\$ 9,248$ & $\$ 3,585$ & $\$ 6,726$ & $\$ 10,732$ \\
\hline $\begin{array}{l}\text { Unrelated } \\
\text { Individuals }\end{array}$ & -- & $\$ 2,436$ & $\$ 2,683$ & $\$ 1,279$ & $\$ 2,037$ & $\$ 3,221$ \\
\hline $\begin{array}{l}\text { Families and unre } \\
\text { Individuals }\end{array}$ & $\begin{array}{l}\text { Tated } \\
\$ 3,301\end{array}$ & $\$ 5,298$ & $\$ 5,712$ & $\$ 3,021$ & $\$ 5,527$ & $\$ 8,279$ \\
\hline
\end{tabular}

Sources: U.S. Bureau of the Census, 1950 Census of Population, Vol. II, Characteristics of the Population, Part 5, California, pp. 5-71 and 5-176. U.S. Census of Population 1960, California, General Social and Economic Characteristics, PC(1) 6C California, pp. 6-435. U.S. Bureau of the Census, 1970 Census of Population, General Social and Economic Characteristics, California. 
TABLE A-10

FAMILY INCOME: MODOC COUNTY AND CALIFORNIA

$1950,1960 \& 1970$

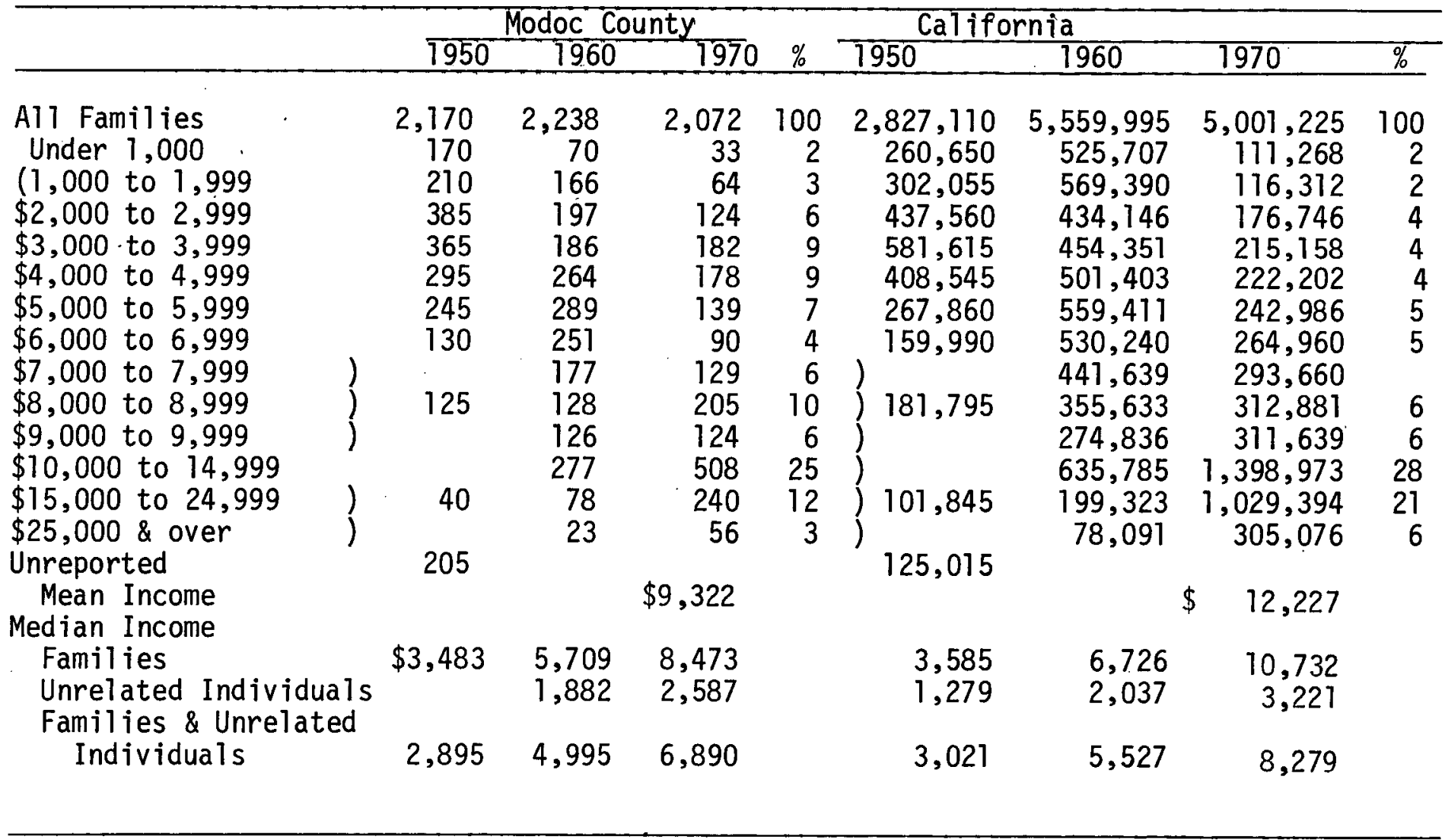

Source: U.S. Bureau of the Census, Census of Population, 1950, 1960 \& 1970, California General Social \& Economic Characteristics "Selected Economic Data" Lassen County, California, Agricultural Extension, University of California. 


\section{TABLE A- 11}

LASSEN COUNTY: PERSONAL INCOME BY MAJOR SOURCE SELECTED YEARS 1950-1969

\begin{tabular}{|c|c|c|c|c|c|c|c|c|c|c|c|c|}
\hline & & $\begin{array}{l}\text { Total } \\
\text { Income }\end{array}$ & $\begin{array}{l}\text { Wages } \\
\text { Salar }\end{array}$ & & $\begin{array}{l}\text { Other } \\
\text { Inco }\end{array}$ & & $\begin{array}{r}\text { Proprie } \\
\text { Inco }\end{array}$ & & $\begin{array}{l}\text { Proper } \\
\text { Incom }\end{array}$ & & $\begin{array}{l}\text { Transfe } \\
\text { Payment }\end{array}$ & \\
\hline & $\$ 1,000$ & $\begin{array}{l}\text { Per- } \\
\text { cent }\end{array}$ & $\$ 1,000$ & $\begin{array}{l}\text { Per- } \\
\text { cent }\end{array}$ & $\$ 1,000$ & $\begin{array}{l}\text { Per- } \\
\text { cent }\end{array}$ & $\$ 1,000$ & $\begin{array}{l}\text { Per- } \\
\text { cent }\end{array}$ & $\$ 7,000$ & $\begin{array}{l}\text { Per- } \\
\text { cent }\end{array}$ & $\$ 1,000$ & $\begin{array}{l}\text { Per- } \\
\text { cent }\end{array}$ \\
\hline 1950 & 31,048 & 100.0 & 21,087 & 67.9 & 489 & 1.6 & 5,032 & 16.2 & 2,087 & 6.7 & 2,353 & 7.6 \\
\hline 1955 & 31,816 & 100.0 & 21,855 & 68.7 & 655 & 2.0 & 5,254 & 16.5 & 1,641 & 5.2 & 2,411 & 7.6 \\
\hline $\begin{array}{l}1960 \\
1961 \\
1962 \\
1963 \\
1964\end{array}$ & $\begin{array}{l}28,800 \\
32,526 \\
35,964 \\
36,868 \\
44,340\end{array}$ & $\begin{array}{l}100.0 \\
100.0 \\
100.0 \\
100.0 \\
100.0\end{array}$ & $\begin{array}{l}18,900 \\
20,867 \\
21,640 \\
24,675 \\
24,574\end{array}$ & $\begin{array}{l}65.6 \\
64.1 \\
60.2 \\
66.9 \\
55.4\end{array}$ & $\begin{array}{r}500 \\
978 \\
917 \\
1,070 \\
1,120\end{array}$ & $\begin{array}{l}1.8 \\
3.0 \\
2.5 \\
2.9 \\
2.5\end{array}$ & $\begin{array}{l}4,100 \\
4,937 \\
5,207 \\
1,970 \\
7,955\end{array}$ & $\begin{array}{r}14.2 \\
15.2 \\
14.5 \\
5.4 \\
17.9\end{array}$ & $\begin{array}{l}2,100 \\
1,942 \\
3,986 \\
4,209 \\
5,432\end{array}$ & $\begin{array}{r}7.3 \\
6.0 \\
11.1 \\
11.4 \\
12.3\end{array}$ & $\begin{array}{l}3,200 \\
3,808 \\
4,214 \\
4,944 \\
5,259\end{array}$ & $\begin{array}{l}11.1 \\
11.7 \\
11.7 \\
13.4 \\
11.9\end{array}$ \\
\hline $\begin{array}{l}1965 \\
1966 \\
1967 \\
1968 \\
1969\end{array}$ & $\begin{array}{l}40,156 \\
44,963 \\
47,391 \\
50,136 \\
53,500\end{array}$ & $\begin{array}{l}100.0 \\
100.0 \\
100.0 \\
100.0 \\
100.0\end{array}$ & $\begin{array}{l}25,997 \\
30,132 \\
31,363 \\
32,751 \\
34,100\end{array}$ & $\begin{array}{l}64.7 \\
67.0 \\
66.2 \\
65.3 \\
63.7\end{array}$ & $\begin{array}{l}658 \\
733 \\
773 \\
771 \\
800\end{array}$ & $\begin{array}{l}1.6 \\
1.7 \\
1.6 \\
1.6 \\
1.5\end{array}$ & $\begin{array}{l}4,866 \\
4,954 \\
5,744 \\
5,532 \\
5,500\end{array}$ & $\begin{array}{l}12.1 \\
11.0 \\
10.9 \\
11.0 \\
10.3\end{array}$ & $\begin{array}{l}3,774 \\
3,968 \\
4,188 \\
4,418 \\
4,800\end{array}$ & $\begin{array}{l}9.4 \\
8.8 \\
8.8 \\
8.8 \\
9.0\end{array}$ & $\begin{array}{l}4,891 \\
5,176 \\
5,923 \\
6,664 \\
8,300\end{array}$ & $\begin{array}{l}12.2 \\
11.5 \\
12.5 \\
13.3 \\
15.5\end{array}$ \\
\hline
\end{tabular}

* Less personal contributions for social insurance.

Source: Economic Survey Series, California Chamber of Commerce, Reserach Dept. 
TABLE $\quad A-12$

MODOC COUNTY: PERSONAL INCOME BY MAJOR SOURCE

SELECTED YEARS 1960 THROUGH 1968

\begin{tabular}{|c|c|c|c|c|c|c|c|c|c|c|c|}
\hline Year & $\begin{array}{l}\text { Total } \\
\text { Income } \\
\$ 1,000 \\
\end{array}$ & $\begin{array}{c}\text { Wages \& } \\
\text { Salaries* } \\
\$ 1,000\end{array}$ & $\%$ & $\begin{array}{l}\text { Other Labor } \\
\text { Income } \\
\$ 1,000 \\
\end{array}$ & $\%$ & 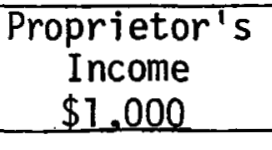 & $\%$ & $\begin{array}{l}\text { Property } \\
\text { Income } \\
\$ 1.000\end{array}$ & $\%$ & $\begin{array}{l}\text { Transfer } \\
\text { Payments } \\
\$ 1,000 \\
\end{array}$ & $\%$ \\
\hline 1960 & 20,588 & 9,704 & 47.1 & 361 & 1.8 & 6,823 & 33.1 & 1,809 & 8.8 & 1,891 & 9.2 \\
\hline 1961 & 20,393 & 10,287 & 50.4 & 428 & 2.1 & 5,730 & 28.1 & 1,878 & 9.2 & 2,070 & 10.2 \\
\hline 1962 & 19,116 & 8,128 & 42.5 & 351 & 1.8 & 6,817 & 35.7 & 1,813 & 9.5 & 2,007 & 10.5 \\
\hline 1963 & 17,747 & 8,728 & 49.2 & 386 & 2.2 & 4,540 & 25.6 & 1,976 & 11.0 & 2,117 & 12.0 \\
\hline 1964 & 20,198 & 9,339 & 46.2 & 419 & 2.1 & 5,336 & 26.4 & 2,885 & 14.3 & 2,219 & 11.0 \\
\hline 1965 & 21,573 & 10,493 & 48.6 & 386 & 1.8 & 5,886 & 27.3 & 2,658 & 12.3 & 2,150 & 10.0 \\
\hline 1966 & 22,976 & 10,827 & 47.1 & 397 & 1.7 & 6,544 & 28.5 & 2,717 & 11.8 & 2,491 & 10.9 \\
\hline 1967 & 25,825 & 12,023 & 46.6 & 479 & 11.9 & 7,340 & 28.4 & 2,953 & 11.4 & 3,030 & 11.7 \\
\hline
\end{tabular}

*Less personal conbributions for social insurance.

Source: California State Chamber of Commerce, "Economic Survey Series" 
Tables 13 through 16 show historical agricultural, mineral and 7 umber valuation data for both counties. The agricultural base in Modoc County is seen to be substantially greater than that for Lassen County, having a five-fold difference in total valuation. Timber production in Lassen county is erratic, but normally greater than Modoc County. Tables 17 and 18 show historical assessed valuation data for both Counties, for the period 1940-1970, with the assessed valuation in Lassen County slightly higher than Modoc County. 
TABLE $\quad A-13$

AGRICULTURAL PRODUCTION-VALUE AND RANK

MODOC COUNTY, CALIFORNIA

\begin{tabular}{|c|c|c|c|c|c|c|c|c|c|c|c|c|}
\hline & & 962 & & & $\underline{1966}$ & & & 1970 & & & 972 & \\
\hline PRODUCT & Value & $\begin{array}{l}\% \text { of } \\
\text { Total }\end{array}$ & Rank & Value & $\begin{array}{l}\% \text { of } \\
\text { Total }\end{array}$ & Rank & Value & $\begin{array}{l}\% \text { of } \\
\text { Total }\end{array}$ & Rank & Value & $\begin{array}{l}\% \text { of } \\
\text { Total }\end{array}$ & Pank \\
\hline Beef & $6,772,300$ & 42.4 & 1 & $7,542,000$ & 37.1 & 1 & $9,610,000$ & 37.7 & 1 & $18,026,200$ & 49.7 & 1 \\
\hline Alfalfa & $1,128,600$ & 7.1 & 6 & $1,497,000$ & 7.4 & 5 & $3,219,000$ & 12.6 & 3 & $4,883,300$ & 13.5 & 3 \\
\hline Potatoes & $2,412,000$ & 15.1 & 2 & $5,400,000$ & 26.5 & 2 & $5,280,000$ & 20.7 & 2 & $5,600,000$ & 15.4 & 2 \\
\hline Meadow Hay & $1,492,800$ & 9.3 & 3 & $1,605,000$ & 7.9 & 4 & $2,898,000$ & 11.4 & 4 & $2,924,100$ & 8.1 & 4 \\
\hline Barley & $i, 304,200$ & 8.2 & 4 & $1,820,000$ & 8.9 & 3 & $1,260,000$ & 4.9 & 5 & $1,732,000$ & 4.8 & 5 \\
\hline Wheat & $1,187,900$ & 7.4 & 5 & 299,000 & 1.4 & 9 & 735,000 & 2.9 & 7 & 775,200 & 2.1 & 6 \\
\hline Oats & 107,900 & 0.7 & 10 & 73,000 & 0.4 & 14 & 72,000 & 0.3 & 12 & 198,000 & 0.5 & 11 \\
\hline Grain Hay & 115,500 & 0.7 & 11 & 410,000 & 2.0 & 7 & 335,000 & 1.3 & 10 & 315,000 & 0.9 & 9 \\
\hline Onions & 511,360 & 3.2 & 7 & 753,000 & 3.7 & 6 & $1,000,000$ & 3.9 & 6 & 629,900 & 1.7 & 7 \\
\hline Misc. Veg. Crops & 50,400 & 0.3 & 15 & 170,000 & 0.8 & 11 & 450,000 & 1.8 & $8^{\circ}$ & 540,000 & 1.5 & 8 \\
\hline Sheep \& Lambs & 356,800 & 2.2 & 8 & 367,000 & 1.8 & 8 & 398,000 & 1.6 & 9 & 316,800 & 0.9 & 10 \\
\hline $\begin{array}{l}\text { Misc. Crops } \\
\text { Rye } \\
\text { Misc. Live./Live. Prod. } \\
\text { Wool }\end{array}$ & $\begin{array}{r}82,000 \\
57,600 \\
\cdot \quad 301,200 \\
105,000\end{array}$ & $\begin{array}{l}0.5 \\
0.4 \\
1.8 \\
0.7\end{array}$ & $\begin{array}{r}13 \\
14 \\
9 \\
12\end{array}$ & $\begin{array}{r}128,000 \\
4,500 \\
183,000 \\
104,000\end{array}$ & $\begin{array}{l}0.6 \\
0.0 \\
1.0 \\
0.5\end{array}$ & $\begin{array}{l}12 \\
15 \\
10 \\
13\end{array}$ & $\begin{array}{c}- \\
150,000 \\
67,700\end{array}$ & $\begin{array}{l}- \\
0 . \overline{7} \\
0.3\end{array}$ & $\begin{array}{l}14 \\
15 \\
11 \\
13\end{array}$ & $\begin{array}{r}119,700 \\
175,000 \\
65,100\end{array}$ & $\begin{array}{l}- \\
0.3 \\
0.5 \\
0.2\end{array}$ & $\begin{array}{l}15 \\
13 \\
12 \\
14\end{array}$ \\
\hline TOTAL & $15,985,560$ & $100 \%$ & & $20,355,500$ & $100 \%$ & & $25,474,700$ & $100 \%$ & & $36,300,300$ & $100 \%$ & \\
\hline
\end{tabular}

Source: Modoc County Agriculture Commissioner 
TABLE A- 14

AGRICULTURAL PRODUCTION-VALUE

LASSEN COUNTY

\begin{tabular}{|c|c|c|c|c|}
\hline & 1954 & 1959 & 1964 & $1969 *$ \\
\hline $\begin{array}{l}\text { Vegetables } \\
\text { Field crops } \\
\text { Fruits and nuts } \\
\text { Livestock } \\
\text { Pouitry } \\
\text { Dairy } \\
\text { Forest Products }\end{array}$ & $\begin{array}{r}190 \\
343,180 \\
694 \\
2,970,862 \\
87,019 \\
167,858 \\
85,230 \\
\end{array}$ & $\begin{array}{r}\$ 3,900 \\
308,621 \\
203 \\
4,131,654 \\
59,239 \\
180,566 \\
52,905 \\
\end{array}$ & $\begin{array}{r}\$ 250 \\
430,959 \\
19 \\
3,735,926 \\
34,251 \\
156,607 \\
93,610 \\
\end{array}$ & $\begin{array}{r}\$ 1,022,816 \\
6,003,263 \\
215,476 \\
\end{array}$ \\
\hline Total & $\$ 3,655,033$ & $\$ 4,737,088$ & $\$ 4,451,622$ & $\$ 7,241,555$ \\
\hline
\end{tabular}

*1969 Figures are for Crops, Livestock Products and Forest Products.

Sources: U.S. Bureau of the Census, U.S. Census of Agriculture, 1954, Vo1. 1, California, Counties.

U.S. Bureau of the Census, U.S. Census of Agriculture, 1959, Vol. 1, California, Counties.

U.S. Bureau of the Census, U.S. Census of Agriculture, 1964, Vol. 1, Part 48, California.

U.S. Bureau of the Census, U.S. Census of Agriculture, 1969. 
TABLE A-15

VALUE OF MINERAL PRODUCTS AND TIMBER

PRODUCTION, MODOC COUNTY, 1950-1971

\begin{tabular}{|c|c|c|}
\hline Year & $\begin{array}{l}\text { Value of Mineral } \\
\text { Products } \\
\$ 1,000\end{array}$ & $\begin{array}{c}\text { Timber } \\
\text { Production } \\
\text { Million Board Ft. }\end{array}$ \\
\hline 1950 & 202 & 222.6 \\
\hline 1955 & 250 & 46.7 \\
\hline 1960 & 584 & 42.3 \\
\hline 1961 & 406 & 59.6 \\
\hline 1962 & 968 & 60.3 \\
\hline 1963 & 646 & 54.7 \\
\hline 1964 & 614 & 48.5 \\
\hline 1965 & 470 & 54.6 \\
\hline 1966 & 540 & 91.8 \\
\hline 1967 & 758 & 78.9 \\
\hline 1968 & 496 & 85.2 \\
\hline 1969 & & 75.9 \\
\hline 1970 & & 99.4 \\
\hline 1971 & & 80.3 \\
\hline
\end{tabular}

Source: California State Chamber of Commerce "Economic Survey Series" California Statistical Abstract

U.S. Bureau of Mines: Mineral Yearbook 


\section{TABLE A- 16}

VALUE OF MINERAL PRODUCTS AND TIMBER PRODUCTION LASSEN COUNTY, 1950-1968

\begin{tabular}{ccc}
\hline Year & $\begin{array}{c}\text { Value of Mineral } \\
\text { Products } \\
\$ 1,000\end{array}$ & $\begin{array}{c}\text { Timber } \\
\text { Production } \\
\text { Million Board Ft. }\end{array}$ \\
1950 & 31 & 230.0 \\
1955 & 306 & 256.8 \\
1960 & 368 & 98.2 \\
1961 & 789 & 121.1 \\
1962 & 293 & 126.7 \\
1963 & 272 & 78.9 \\
1964 & 373 & 134.3 \\
1965 & $\mathrm{n.a}$ & 129.6 \\
1966 & 623 & 111.0 \\
1967 & 436 & 74.2 \\
1968 & 1,197 & 88.6 \\
\hline
\end{tabular}

Source: "Economic Survey Series", California State Chamber of Commerce. 
TABLE $\quad A-17$

ASSESSED VALUATION OF COUNTY-ASSESSED TANGIBLE PROPERTY BY CLASS OF PROPERTY FOR LASSEN COUNTY, 1940-1970

\begin{tabular}{|c|c|c|c|c|c|}
\hline & Land & Improvements & $\begin{array}{l}\text { Personal } \\
\text { Property* }\end{array}$ & Exemptions & Net Total \\
\hline & & & $\$ 1,000$ & & \\
\hline 1940 & 6,856 & 3,282 & 2,141 & 176 & 12,103 \\
\hline 1950 & 6,606 & 3,735 & 4,471 & 421 & 14,390 \\
\hline 1955 & 6,237 & 4,424 & 4,439 & 677 & 14,423 \\
\hline $\begin{array}{l}1960 \\
1961 \\
1962 \\
1963 \\
1964\end{array}$ & $\begin{array}{l}6,458 \\
6,630 \\
7,569 \\
7,628 \\
8,471\end{array}$ & $\begin{array}{l}6,847 \\
6,958 \\
7,171 \\
8,149 \\
8,489\end{array}$ & $\begin{array}{l}4,217 \\
4,114 \\
3,738 \\
3,913 \\
3,980\end{array}$ & $\begin{array}{r}964 \\
977 \\
1,014 \\
1,164 \\
1,218\end{array}$ & $\begin{array}{l}16,558 \\
16,725 \\
17,464 \\
18,526 \\
19,722\end{array}$ \\
\hline $\begin{array}{l}1965 \\
1966 \\
1967 \\
1968 \\
1969 \\
1970\end{array}$ & $\begin{array}{r}8,751 \\
9,378 \\
10,758 \\
11,507 \\
12,979 \\
15,914\end{array}$ & $\begin{array}{r}9,021 \\
9,563 \\
10,739 \\
11,939 \\
12,542 \\
13,110\end{array}$ & $\begin{array}{l}4,105 \\
4,652 \\
4,884 \\
4,547 \\
4,419 \\
3,433\end{array}$ & $\begin{array}{l}1,221 \\
1,225 \\
1,171 \\
1,323 \\
1,179 \\
1,187\end{array}$ & $\begin{array}{l}20,656 \\
22,368 \\
25,210 \\
26,670 \\
28,761 \\
31,270\end{array}$ \\
\hline
\end{tabular}

* Includes money not on deposit, 1940 through 1956 only.

Source: "Annual Report," California State Board of Equalization. 
TABLE A- 78

ASSESSED VALUATION OF COUNTY--ASSESSED TANGIBLE PROPERTY

BY CLASS OF PROPERTY FOR MODOC COUNTY, 1940 - 1970

$(\$ 1,000)$

\begin{tabular}{lccccc}
\hline Year & Land & Improvements & $\begin{array}{c}\text { Personal } \\
\text { Property* }\end{array}$ & Exemptions & $\begin{array}{c}\text { Net } \\
\text { Total }\end{array}$ \\
\hline 1940 & 5,243 & 1,491 & 1,607 & 135 & 8,208 \\
1950 & 4,274 & 2,381 & 4,796 & 225 & 11,226 \\
1955 & 8,240 & 5,138 & 5,297 & 312 & 18,363 \\
1960 & 8,429 & 5,808 & 5,313 & 391 & 19,159 \\
1961 & 8,364 & 5,858 & 5,238 & 412 & 19,048 \\
1962 & 8,370 & 6,379 & 4,805 & 455 & 19,099 \\
1963 & 8,391 & 6,458 & 4,952 & 451 & 19,350 \\
1964 & 8,968 & 6,583 & 4,719 & 445 & 19,825 \\
1965 & 9,570 & 6,815 & 4,548 & 420 & 20,513 \\
1966 & 10,731 & 6,960 & 4,821 & 411 & 22,101 \\
1967 & 12,912 & 6,876 & 5,350 & 402 & 24,726 \\
1968 & 14,012 & 6,907 & 4,668 & 381 & 25,206 \\
1969 & 15,509 & 7,217 & 4,549 & 370 & 26,905 \\
1970 & 17,812 & 7,304 & 2,938 & 354 & 27,700 \\
& & 6 & & & \\
\hline
\end{tabular}

* Includes money not on deposit, 1940-1956 only.

Source: "Annual Report", California State Board of Equilization 


\section{REFERENCES}

1. ERDA Report SAN-1077-4, Susanville Geothermal Energy Project, Workshop Proceedings July 1976

2. The Potential of Low Temperature Geothermal Resources in California, Division of $0 i l$ and Gas, Geothermal Unit, Report No. TR 13.

3. Chemistry of Thermal Water in Selected Geothermal Areas of California, Cal ifornia Division of $0 i 1$ and Gas, Report No. TR 15.

4. Dracup, J., at al, Waste Nutrient Recycling Using Hydrophonic Aquacul tural Methods, University of California, 1975.

5. Geo-Heat Utilization Center, Quarterly Bulletin, July 1976, Oregon Institute of Technology.

6. California Public Utilities Commission, personal interview and telephone conversations to obtain shipping rates.

7. Southern Pacific Railroad Advertisement in Traffic Management Magazine, Spring 1976.

8. Chicken Fryer Production: Management, Costs and Returns, Division of Agricultural Sciences, University of California, Leaflet 2648.

9. Conceptual Study for Total Utilization of an Intermediate Temperature Geothermal Resource; ANCR-1260, UC-66, INEL.

10. Wartes, Lloyd, The Solar Greenhouse: A Means to Increased Food Production, Solar Engineering, October 1976.

11. Crop Processes in Controlled Environments, Proceedings of International Symposium held at Glasshouse Crops Research Institute, Little Hampton, Sussex, England, July 1971. Edited by A.R. Rees, K.E. Cockshu11, D.W. Hand and R.G. Hurd.

12. Cow-Calf, Economics, Cecil Pierce, Modoc County Farm Advisor, Proceeding: Klamath, Lake, Modoc, Stockman's Day.

13. Young, B.A., A practical Method for Calculating Cold Stress in Cattle. University of Alberta, Canáda, Feeders' Day 1971.

14. Young, B.A. and Christopherson, R.J., Effect of Prolonged Cold Exposure on Digestion and Metapolism in Ruminants, American Society of Agricultural Engineers, Livestock Environment Proceeding of the International Livestock Symposium, Lincoln, Nebraska, 1974, Special Publication SP-0174.

15. Management Options for Cattle Producers, Eisgruber, L.M., Klamath-Lake-Modoc Stockman's Day, September 17, 1976.

16. USDA Dwg. Ex. 5862, Prepared by Oregon State College, Corvallis, Oregon, for USDA. 
17. Barrette, B.R., Lucke, D.R., The Forest Resources in the Timber Industry of the North Cal-Neva Resource Conservation and Development Project, Joint Study, California Division of Forestry, U.S. Forest Service, Soil Conservation Service, 1975.

18. Kiln-Drying Western Softwoods, Moore Dry Kiln Company, North Portland, Oregon.

19. Bardach, J.E., Ryther, J.H., and McLarney, W.O., Aquaculture, the Farming and Husbandry of Freshwater and Marine Organisms, Wiley Interscience 1972.

20. Johnson, B., Aquaculture at Oregon Institute of Technology, Geo-Heat Utilization Center Quarterly Bulletin, Oregon Institute of Technology, July 1976.

21. Knight, Allen, and others, Laboratory Studies on Selected Nutritional, Physical and Chemical Factors Affecting the Growth Survival, Respiration and Biogenetics of the Giant Prawn, Macrobrachium rosenbergi i, Hydrobiology Laboratory, Department of Water Science and Engineering, University of California, Davis, March 1976.

22. Goodwin, H.L., and Hanson, J.A., The Aquaculture of Freshwater Prawns (Macrobrachium species), the Oceanic Institute, Waimaualo, Hawai $1,1975$.

23. Sandifer, P.A., and Smith, T.I., Experimental Aquaculture of the Malaysian Prawn, Macrobrachium rosenbergij (DeMan) in South Carolina, U.S.A., Food and Agriculture Organization of The United Nations, Rome, Italy, 1976.

24. Sandifer, P.A., Smith, T.I., Development of a Crustacean Mariculture Program at South Carolina's Marine Resources Research Institute, Proceedings of Fifth Annual Workshop, World Mariculture Society, 1974.

25. Knight, Dr. W. Allen, personal interview at U.C. Davis.

26. Wall Street Journal, Sept. 20, 1976, Commodities--"Freshwater 'Rough' Fish Are Winning More Acceptability at U.S. Tables."

27. Geothermal Related Corrosion Testing, Silva, J., Geo-Heat Utilization Bulletin, Oregon Institute of Technology, October 1975.

28. Lindal, B., Industrial and other Applications of Geothermal Energy, UNESCO 1973 Geothermal Energy (Earth Sciences, 12).

29. They're not 'biting' at his bark, Chemical Week, December 22, 1976. 